\title{
Disseminação da resistência a antimicrobianos em cepas clínicas e ambientais de Enterobacteriaceae: identificação e mapeamento do ambiente genético de genes codificadores de ESBL.
}

\section{Milena Dropa}

Tese apresentada ao Programa de Pós-Graduação em Saúde Pública da Faculdade de Saúde Pública da Universidade de São Paulo para obtenção do título de Doutor em Ciências.

Área de concentração: Serviços de Saúde Pública.

Orientação: Prof ${ }^{a}$. Associada Maria Helena Matté.

São Paulo

2012 
É expressamente proibida a comercialização deste documento tanto na sua forma impressa como eletrônica. Sua reprodução total ou parcial é permitida exclusivamente para fins acadêmicos e científicos, desde que na reprodução figure a identificação do autor, título, instituição e ano da tese 


\section{DEDICATÓRIA}

À minha família, mais uma vez, Paizinho, Ligia, Mãezinha, Nina, Mô, Frê e Lucca, sem vocês nada disso faria sentido. 



\section{AGRADECIMENTOS}

A Deus, pela minha vida, pela minha saúde, e por toda a proteção e luz em meu caminho.

À minha família...

Ao meu pai, por me ensinar que eu sempre posso, e que conhecimento não se perde, e à Ligia, essa alma maravilhosa que eu admiro demais...

À minha mãe, pela minha vida e pelo orgulho que sente das minhas conquistas...

À minha irmã Marina (Bã!), a quem eu sempre tentei ensinar e sempre acabei aprendendo algo...

À minha irmã Mônica e meu irmão de coração Frê, apenas agradecer nunca será suficiente...

Ao meu sobrinho Lucca, essa alma especial que aos 4 anos já me ensina lições que eu ainda não havia aprendido...

Ao King, meu filhote de quatro patas, por esses oito anos de amor incondicional..."Seja a pessoa que seu cão pensa que você é!"

A toda minha família, por não entender muito bem o que eu faço, e mesmo assim se orgulharem das minhas conquistas...

Obrigada! Amo todos vocês!!!

À professora Maria Helena Matté, pela orientação e por acreditar neste tema e em mais este projeto, muito obrigada!

Ao professor Glavur Rogério Matté, pelo apoio e suporte durante este trabalho, e por apostar em minha carreira.

Ao professor Nilton Lincopan, por toda colaboração e apoio intelectual desde o primeiro contato durante meu mestrado até hoje, e pela participação na avaliação desta tese.

Às professoras Maria Inês Sato, Maria Tereza Pepe Razzolini e Ana Cristina Gales, por doarem seu tempo para participar da avaliação deste trabalho.

Aos queridos estagiários Flávia Nacache e Rafael Arrabaça de Carvalho, e aprimorandas Bruna Aguiar e Ana Paula Amaral, pela ajuda essencial na reta final deste trabalho. 
À equipe do Laboratório de Prática de Saúde Pública, e a todos os aprimorandos e estagiários que colaboraram de alguma forma com a realização deste projeto desde 2009 , muito obrigada!

À Fundação de Amparo à Pesquisa de Estado de São Paulo (FAPESP), pelo financiamento dos dois projetos regulares que possibilitaram a realização deste trabalho (Processos Fapesp 2008/08312-3 e 2010/12841-1).

Às minhas amigas...

Regina, minha irmã de coração, tão longe e tão perto, sempre torcendo pelo meu sucesso!

Livia, minha pequena grande pessoa, obrigada por me ajudar neste trabalho, você é uma parceira incrível, pesquisadora da qual eu me orgulho sempre, e de quebra ainda me empresta sua família quando a minha não está por perto!

Ronalda, companheira pra todas as horas, tem o dom de falar sem ofender, de fazer rir, de deixar os momentos sempre mais alegres, de cuidar, obrigada pela sua amizade, admiro você demais!

Martha, minha amiga corajosa, por todos os momentos que se fez presente, mesmo estando tão longe, você faz muita falta nos meus cafés e na minha vida!

Danielle (DanE!), por toda ajuda durante este projeto, pelo companheirismo e amizade dentro e fora do laboratório, e por estar sempre por perto!

Marina, por toda ajuda no laboratório, por se interessar pelo meu projeto, e pelas conversas distraídas e divertidas que sempre me fazem rir muito!

Bruna, por todos os PCRs e géis, pela dedicação e cuidado com o meu trabalho, e pela amizade e confiança, admiro muito sua personalidade e sua alma generosa!

Renata Leal, minha professora e amiga, obrigada por todas as conversas divertidas e pelos alongamentos e fisioterapias pra que eu pudesse continuar este trabalho maltratando menos minha postura!

Cybele, minha amiga da porta ao lado, por todas as conversas e principalmente pelo cuidado que tem comigo!

$\mathrm{E}$ a todos os meus amigos que estiveram por perto durante esses quatro anos, me apoiando e encorajando, e principalmente se orgulhando de mim!

Muito obrigada!!! 


\section{EPÍGRAFE}

"Toda célula viva carrega consigo a experiência de um bilhão de anos de experimentações por seus ancestrais."

(Max Delbrück) 



\section{RESUMO}

Dropa M. Disseminação da Resistência a Antimicrobianos em Cepas Clínicas e Ambientais de Enterobacteriaceae: Identificação e Mapeamento do Ambiente Genético de Genes Codificadores de ESBL [Tese de Doutorado]. São Paulo: Faculdade de Saúde Pública da USP; 2012.

Introdução. A resistência bacteriana é facilitada pela pressão seletiva do uso de antimicrobianos na clínica e em outras atividades, como a agricultura e pecuária, além de poder ser disseminada para a natureza por meio do lançamento inadequado do esgoto ou pela aplicação do lodo de esgoto na agricultura. As $\beta$-lactamases de espectro estendido (ESBL) são uma das formas mais prevalentes de resistência em Gram negativos no mundo, e seus genes codificadores são disseminados por meio de diversos elementos genéticos, principalmente transposons e integrons mobilizados para plasmídios. Objetivo. Identificar e caracterizar genes codificadores de ESBL, bem como suas prováveis formas de mobilização, em enterobactérias isoladas de fontes ambientais e clínicas. Material e Métodos. Quarenta e cinco cepas isoladas de um hospital público em 2004 e 2005, responsáveis por infecções hospitalares (14), infecções comunitárias (7) e colonizações (24), e 7 isoladas de estações de tratamento de esgoto (ETE) em 2009, em São Paulo, geneticamente distintas e produtoras de ESBL da família Enterobacteriaceae, foram estudadas. A técnica de PCR seguida de sequenciamento foi utilizada para a identificação dos genes $b l a_{\mathrm{ESBL}}$, triagem de elementos móveis e mapeamento do ambiente genético de $b l a_{\mathrm{ESBL}}$. A identificação dos grupos de incompatibilidade plasmidial (Inc) foi realizada pela técnica de PBRT, e a determinação dos tamanhos dos plasmídios pela técnica de S1-PFGE. Resultados. Os genes $b l a_{\mathrm{ESBL}}$ identificados foram: amostras clínicas $-b l a_{\mathrm{TEM}-15}, b l a_{\mathrm{TEM}-197}, b_{\mathrm{SHV}-5}$,

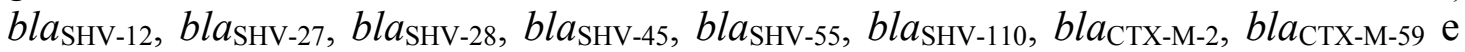
bla $a_{\mathrm{CTX}-\mathrm{M}-131}$; amostras ambientais - bla $_{\mathrm{SHV}-28}$, bla $_{\mathrm{CTX}-\mathrm{M}-15}$ e bla $a_{\mathrm{CTX}-\mathrm{M}-8}$. Os genes $b l a_{\mathrm{TEM}-}$ 15 e bla $a_{\mathrm{TEM}-197}$ estavam associados aos elementos $\mathrm{Tn} 2 *$ e $\mathrm{Tn} 3$, respectivamente. Os genes $b l a_{\mathrm{SHV}-5}$ e $b l a_{\mathrm{SHV}-12}$ estavam associados à IS26, e não foi possível determinar o ambiente genético dos demais genes $b l a_{\mathrm{SHV}}$. Os genes $b l a_{\mathrm{CTX}-\mathrm{M}-2}, b l a_{\mathrm{CTX}-\mathrm{M}-59}$ e $b l a_{\mathrm{CTX}}$ M-131 estavam inseridos em integrons de classe 1 complexos, bla $a_{\mathrm{CTX}-\mathrm{M}-15}$ estava associado à ISEcp 1 interrompida pela IS26, e bla $a_{\text {CTX-M-8 }}$ estava associado à IS10, também interrompida pela IS26. Os principais grupos Inc detectados foram IncA/C $(37 \%)$ e IncF $(30,4 \%)$. Exceto por 7 cepas clínicas, todas apresentavam plasmídios de alto peso molecular, entre $48,5 \mathrm{~kb}$ e $388 \mathrm{~kb}$. Conclusões. Este estudo detectou 15 genes $b l a_{\mathrm{ESBL}}$ diferentes, dos quais dois são genes novos (bla $a_{\mathrm{TEM}-197}$ e $\left.b l a_{\mathrm{CTX}-\mathrm{M}-131}\right)$ e três são inéditos no Brasil (bla $a_{\mathrm{TEM}-15}, b_{\mathrm{SHV}-55}$ e $\left.b l a_{\mathrm{SHV}-110}\right)$. A maioria das cepas deste estudo possuía genes bla $a_{\mathrm{ESBL}}$ associados a elementos mobilizáveis, bem como continham plasmídios de grupos Inc envolvidos na disseminação da resistência antimicrobiana. Além disso, carreavam plasmídios provavelmente conjugativos. Os resultados deste estudo mostram genes de resistência associados a elementos mobilizáveis em cepas contendo elementos transferíveis. As cepas foram isoladas tanto em uma instituição de saúde como nas ETEs da Grande São Paulo, mostrando o potencial de disseminação da resistência da clínica para o ambiente em nossa região.

Descritores: Saúde Pública; Resistência antimicrobiana; Transferência genética horizontal; $\beta$-lactamases; ESBL; Plasmídios; Integrons; Transposons. 



\begin{abstract}
Dropa M. Disseminação da Resistência a Antimicrobianos em Cepas Clínicas e Ambientais de Enterobacteriaceae: Identificação e Mapeamento do Ambiente Genético de Genes Codificadores de ESBL / Spread of Antimicrobial Resistance in Enterobacteriaceae clinical and environmental strains: Identification and Genetic Environment Mapping of ESBL Encoding Genes [Thesis]. São Paulo (BR): Faculdade de Saúde Pública da USP; 2012.
\end{abstract}

Introduction. Bacterial resistance is facilitated by selective pressure of antimicrobial use in clinical and other activities, as agriculture and livestock, and can be spread to nature through the inadequate discharge of sewage or by the use of sludge in agriculture. Extended-spectrum $\beta$-lactamases (ESBL) are the most prevalente forms of resistance in Gram-negative bacteria in the world, and their encoding genes are disseminated through several genetic elements, especially transposons and integrons mobilized to plasmids. Objective. To identify and characterize ESBL-encoding genes, as well as their probable mobilization pathways, in enterobacteria isolated from clinical and environmental sources. Material and Methods. Forty-five strains isolated from a public hospital in 2004 and 2005, responsible for hospital infections (14), community-acquired infections (7) and colonizations (24), and 7 isolated from sewage treatment plants (ETE) in 2009, in São Paulo, genetically distinct and ESBL producers from Enterobacteriaceae family, were studied. PCR technique followed by sequencing was used for bla $a_{\mathrm{ESBL}}$ genes identification, mobile elements screening and bla $_{\mathrm{ESBL}}$ genetic environment mapping. Plasmid incompatibility groups (Inc) were identified by PBRT technique, and plasmid sizes were determined by S1-PFGE technique. Results. The bla $a_{\mathrm{ESBL}}$ genes identified were: clinical samples - bla $a_{\mathrm{TEM}-15}$, bla $_{\mathrm{TEM}-197}$, bla $_{\mathrm{SHV}-5}$, bla $_{\mathrm{SHV}-12}$, bla $_{\mathrm{SHV}-27}$, bla $_{\mathrm{SHV}-28}$, bla $_{\mathrm{SHV}-45}$, bla $_{\mathrm{SHV}-55}, b_{\mathrm{SHV}-110}$, bla $a_{\mathrm{CTX}-\mathrm{M}-2}, b l a_{\mathrm{CTX}-\mathrm{M}-59}$ and $b l a_{\mathrm{CTX}-\mathrm{M}-131}$; environmental samples - bla $a_{\mathrm{SHV}-28}, b_{a_{\mathrm{CTX}-\mathrm{M}-15}}$ and bla $_{\mathrm{CTX}-\mathrm{M}-8}$. Genes $b l a_{\mathrm{TEM}-15}$ and bla $a_{\mathrm{TEM}-197}$ were associated to the elements $\operatorname{Tn} 2 *$ and Tn3, respectivelly. Genes bla $a_{\mathrm{SHV}-5}$ and bla $a_{\mathrm{SHV}-12}$ were associated to IS26, and it was not possible to detect the genetic environment of the other bla $a_{\mathrm{SHV}}$ genes. Genes bla $a_{\mathrm{CTX}-\mathrm{M}-2}$, bla $a_{\mathrm{CTX}-\mathrm{M}-59}$ and bla $a_{\mathrm{CTX}-\mathrm{M}-131}$ were inserted in complex class 1 integrons, bla $a_{\mathrm{CTX}-\mathrm{M}-15}$ was associated to ISEcpl interrupted by IS26, and bla $a_{\mathrm{CTX}-\mathrm{M}-8}$ was associated to IS 10, also interrupted by IS26. The most common Inc grups detected were IncA/C (37\%) and IncF (30,4\%). Except for 7 clinical strains, all isolates showed high molecular weight plasmids, rangng from $48,5 \mathrm{~kb}$ to $388 \mathrm{~kb}$. Conclusions. This study detected 15 different $b l a_{\mathrm{ESBL}}$ genes, from which 2 are new genes $\left(b l a_{\mathrm{TEM}-197} \mathrm{e}\right.$ $\left.b l a_{\mathrm{CTX}-\mathrm{M}-131}\right)$ and 3 are still unpublished in Brazil $\left(b l a_{\mathrm{TEM}-15}, b l a_{\mathrm{SHV}-55}\right.$ and $\left.b l a_{\mathrm{SHV}-110}\right)$. Most of the strains from this study had bla $a_{\mathrm{ESBL}}$ genes associated to mobile elements, as well as they had plasmids from Inc groups involved in the spread of antimicrobial resistance. Moreover, the strains probably carried conjugative plasmids. Results from the present work show resistance genes associated to mobile elements in strains carrying transferable elements. The strains were isolated either from a healthcare institution or from ETEs in São Paulo, which shows the spread potential of resistance from the clinic to the environment in our region.

Descriptors: Public Health; Antimicrobial resistance; Horizontal gene transfer; $\beta$ lactamases; ESBL; Plasmids; Integrons; Transposons. 
. 


\section{ÍNDICE}

1. INTRODUÇÃ

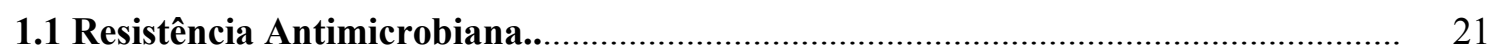

1.1.1 Comunidade e Serviços Relacionados à Saúde ......................................................... 23

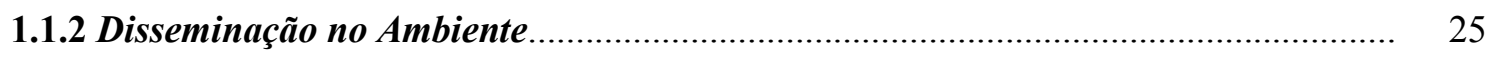

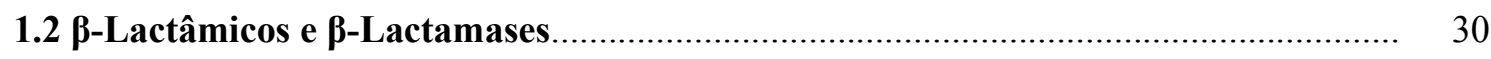

1.2.1 $\beta$-Lactamases de Espectro Estendido - ESBL ........................................................... 33

1.2.2 Mobilização dos Genes Codificadores de ESBL.................................................... 37

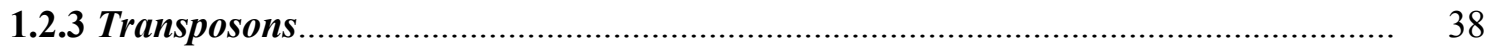

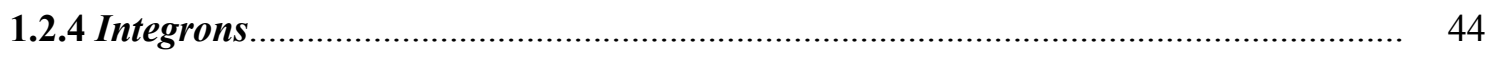

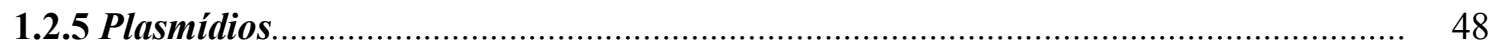

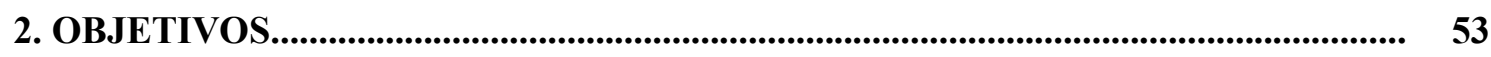

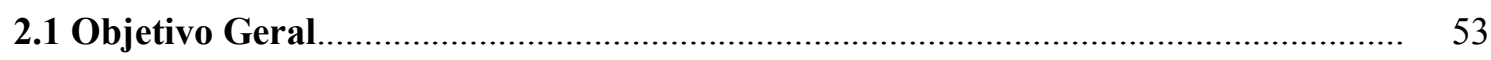

2.2 Objetivos Específicos..................................................................................... 53

3. MATERIAL E MÉTODOS....................................................................................... 54

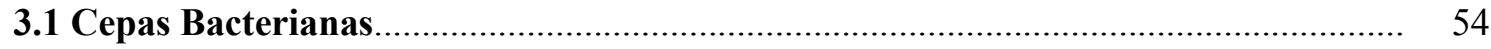

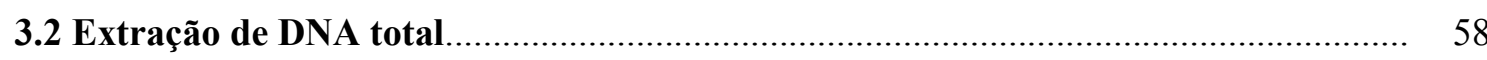

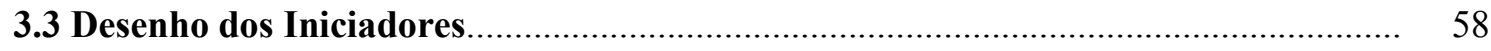

3.4 Pesquisa de Genes Codificadores de ESBL pela PCR ............................................... 59

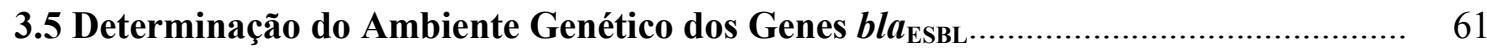

3.5.1 Genes bla

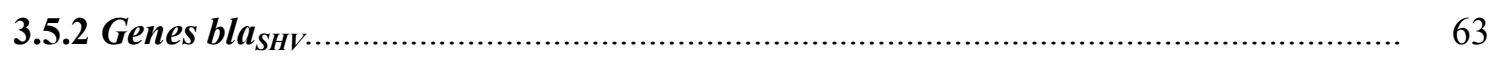

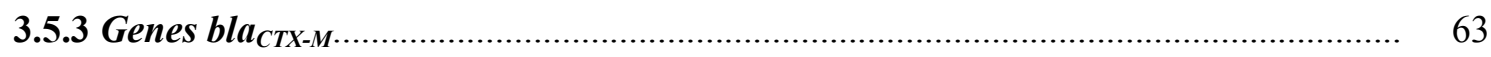

3.6 Tipagem Plasmidial por PCR-Based Replicon Typing (PBRT)................................. 64

3.7 Detecção e Determinação do Tamanho dos Plasmídios................................................ 67

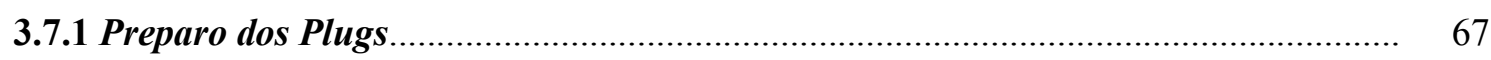

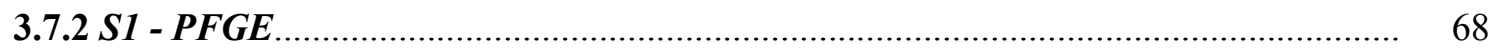




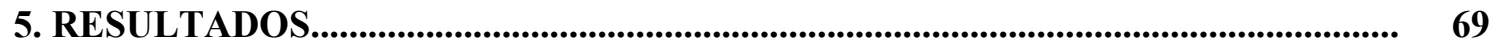

4.1 Deteç̧ão de Genes $b l a_{\text {ESBL }}$ pela PCR ........................................................................ 69

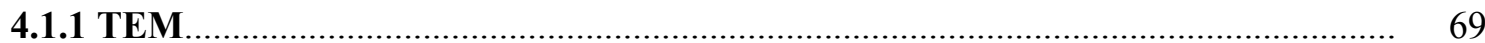

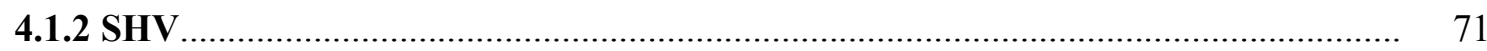

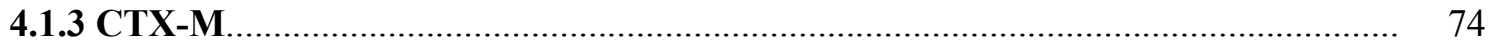

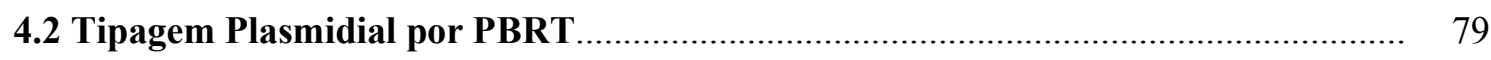

4.3 Deteç̧ão e Determinação do Tamanho dos Plasmídios............................................... 80

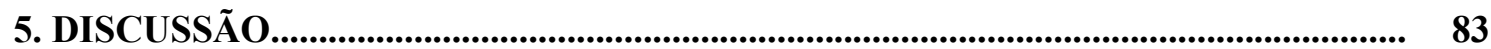

5.1 Genes bla

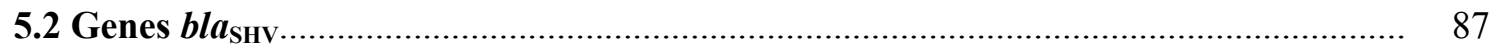

5.3 Genes bla

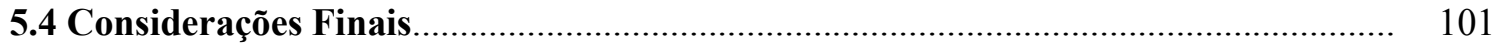

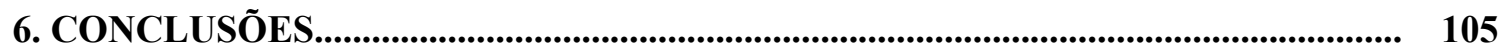

7. REFERÊNCIAS BIBLIOGRÁFICAS.................................................................... 106 


\section{Lista de Quadros}

Quadro 1. Principais grupos de antimicrobianos $\beta$-lactâmicos.................................. 31

Quadro 2. Classificação geral das $\beta$-lactamases............................................................ 32

Quadro 3. Relação das cepas-controle utilizadas nas reações de PCR do estudo..................... 59

Quadro 4. Seqüências dos iniciadores desenvolvidos neste estudo para a pesquisa dos genes $b l a_{\mathrm{ESBL}}$

Quadro 5. Seqüências de iniciadores utilizados na triagem dos elementos genéticos móveis relacionados aos genes bla $a_{\mathrm{ESBL}}$

Quadro 6. Sequências de iniciadores para a tipagem plasmidial em grupos Inc. 66

Quadro 7. Relação dos números de acesso ao banco de dados GenBank para os genes novos e genes relatados pela primeira vez no Brasil. 



\section{Lista de Tabelas}

Tabela 1. Características das cepas clínicas e ambientais produtoras de ESBL selecionadas para o estudo.

Tabela 2. Número e porcentagem de cepas clínicas e ambientais positivas para a presença de cada grupo de genes bla.

Tabela 3. Características das cepas clínicas de $K$. pneumoniae contendo genes bla $\mathrm{TEM}_{\mathrm{TE}}$ que codificam enzimas ESBL

Tabela 4. Número e porcentagem de cepas produtoras de ESBL do grupo CTX-M-2, de acordo com a classificação do tipo de infecção.

Tabela 5. Cepas ambientais isoladas no estudo, de acordo com o local de isolamento, tipo de amostra, enzimas ESBL detectadas e grupos de incompatibilidade plasmidial (Inc).

Tabela 6. Conjuntos de genes bla $a_{\mathrm{ESBL}} \mathrm{e}$ respectivos ambientes genéticos, grupos de incompatibilidade plasmidial (Inc) e plasmídios de alto peso molecular. 



\section{Lista de Figuras}

Figura 1. Vias de transmissão da resistência a antimicrobianos entre diversas fontes...... 29

Figura 2. Estrutura esquemática das Sequências de Inserção e Transposons.................... 40

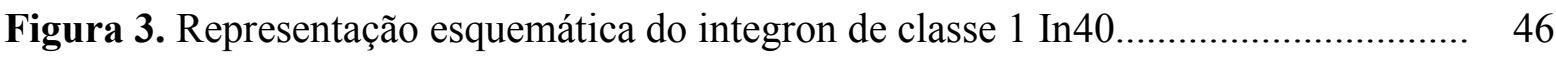

Figura 4. Representação esquemática do Integron de Classe 1 Complexo....................... 48

Figura 5. Representação esquemática dos tipos de mobilização plasmidial..................... 51

Figura 6. Esquema da estrutura dos transposons Tn 1,2 e 3 quando associados a genes

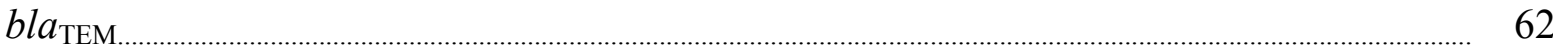

Figura 7. Esquema da associação mais comum entre IS26 e genes $b l a_{\mathrm{SHV}} \ldots \ldots \ldots \ldots \ldots \ldots \ldots . . . . . . . . . . . .63$

Figura 8. Esquema do integron de classe 1 complexo................................................. 63

Figura 9. Possíveis associações das sequências de inserção ISEcpl e IS26 com genes

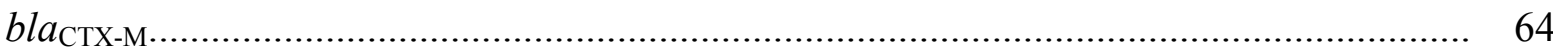

Figura 10. Representação esquemáttica do ambiente genético dos genes $b l a_{\mathrm{TEM}} \cdot \cdots . . . . . . . . . \quad 71$

Figura 11. Distribuição em porcentagem das cepas produtoras de ESBL do grupo SHV de acordo com o setor hospitalar onde foram isoladas.

Figura 12. Número de cepas produtoras de ESBL do grupo SHV de acordo com o tipo de infecção

Figura 13. Representação esquemáttica do ambiente genético dos genes $b l a_{\mathrm{SHV}-5} \mathrm{e}$ $b l a_{\mathrm{SH}-1}$

Figura 14. Distribuição das cepas produtoras de ESBL do grupo CTX-M-2, de acordo com o setor hospitalar onde que foram isoladas.

Figura 15. Representação esquemáttica do ambiente genético dos genes $b l a_{\text {СТХ-M } \cdots \cdots \cdots \cdots . . . .} 78$

Figura 16. Eletroforese em campo pulsado após a digestão com $\mathrm{S} 1$ nuclease 80 



\section{INTRODUÇÃO}

\subsection{Resistência Antimicrobiana}

O tratamento e a prevenção de infecções se tornaram possíveis na medicina a partir da década de 1930, com o uso das sulfonamidas, seguido da descoberta de antibióticos naturais (1940 a 1960) e do sucesso obtido pela modificação dos mesmos, até a década de 1980. Posteriormente, o desenvolvimento de antimicrobianos teve uma severa diminuição, por fatores como a dificuldade de se descobrir novos princípios ativos (especialmente contra Gram negativos), a complexidade dos processos regulatórios para introdução de novos medicamentos no mercado, e o baixo custo-benefício para as indústrias em desenvolver drogas utilizadas em tratamentos de curto prazo (LIVERMORE 2012).

A resistência antimicrobiana é um fenômeno natural de evolução dos microrganismos, e surge normalmente após mutações e recombinações genéticas. Por definição, é a habilidade de um microrganismo de sobreviver a concentrações de antimicrobianos que matariam células sensíveis do mesmo clone. A exposição aos antimicrobianos, seja no corpo humano, em animais ou no ambiente, aplica uma pressão seletiva que favorece o crescimento de bactérias naturalmente resistentes ou a aquisição de genes de resistência por cepas suscetíveis (BAQUERO et al. 2008; ASM 2009).

Bactérias Gram negativas possuem mecanismos de defesa contra os antimicrobianos por meio de alterações nas proteínas ligadoras de penicilina (PBPs Penicillin-binding Proteins), o que ocorre em espécies mais fastidiosas 
(Haemophillus influenzae e Neisseria meningitidis) e com menos frequência, e pela produção de $\beta$-lactamases periplasmáticas e bombas de efluxo na membrana citoplasmática. Essa combinação de depuração plasmática (clearance) com impermeabilidade explica a maior resistência de microrganismos Gram negativos em relação aos Gram positivos, e também o porque da dificuldade de se desenvolver novos antimicrobianos contra eles (LIVERMORE 2012).

Células bacterianas resistentes podem se replicar originando clones resistentes, como também podem transmitir genes de resistência por meio da transferência horizontal, na qual a informação genética é transmitida de uma célula bacteriana para outra, e permite que determinantes de resistência sejam disseminados para microrganismos ambientais ou comensais inofensivos e para patógenos, criando assim reservatórios de resistência (BAQUERO et al. 2008; LORD SOULSBY OF SWAFFHAM PRIOR 2008; ASM 2009).

Alguns fatores que possuem papel importante no desenvolvimento da resistência são o uso de antimicrobianos na medicina humana e veterinária, na agricultura e na criação de animais, e o descarte dos mesmos no ambiente, facilitando a disseminação da resistência principalmente pela transferência genética horizontal e por fatores como trânsito de humanos e animais (insetos, aves, roedores e animais selvagens), fluxo das águas superficiais e oceânicas, e poeira. Assim, o trato gastrintestinal (TGI) de determinados animais e do homem pode ser um importante reservatório de cepas comensais multi-resistentes, as quais podem causar infecções oportunistas ou ainda transferir genes de resistência para patógenos sensíveis que 
venham a causar infecções (ASM 2009; HAWKEY \& JONES 2009; GARCIAALVAREZ et al. 2012).

\subsubsection{Comunidade e Serviços Relacionados à Assistência à Saúde}

A resistência aos antimicrobianos tornou-se um dos assuntos mais preocupantes no que se refere à saúde coletiva mundial, uma vez que sua evolução e disseminação ocorrem mais rapidamente que a conscientização sobre o controle do uso de antimicrobianos e o desenvolvimento de novas drogas.

O uso inadequado dos antimicrobianos, como em infecções virais e parasitárias, e a administração de antimicrobianos em doses abaixo das recomendadas (sub-doses), são fatores que podem gerar o aumento da população bacteriana resistente, além de possuírem pouco ou nenhum efeito sobre a morbidade e a mortalidade. Sub-doses de antimicrobianos também aumentam a tendência à mutação nas bactérias expostas, pela ativação de uma resposta SOS para reparo do DNA, além de resultar na seleção de cepas que aumentam a expressão de seus genes de resistência pré-existentes quando em contato com o antimicrobiano (ANSARI \& MALIK 2009; ASM 2009).

Os conceitos e critérios para definição de infecções hospitalares e comunitárias foram estabelecidos pela Portaria 2.616 da Agência Nacional de Vigilância Sanitária, de 12 de maio de 1998 (ANVISA 1998).

A infecção hospitalar, ou relacionada à assistência à saúde, é aquela adquirida após a admissão do paciente e que se manifeste durante a internação ou após a alta, quando puder ser relacionada com a internação ou procedimentos hospitalares. Estas 
infecções contribuem para elevar os índices de morbidade e mortalidade, prolongar os períodos de internação, aumentar os custos de tratamento, e principalmente representam uma ameaça constante de disseminação de bactérias multi-resistentes (ANVISA 1998; EL FAR et al. 2001; YOKOE \& CLASSEN 2008).

Infecções comunitárias, por sua vez, são aquelas constatadas ou em incubação no ato de admissão do paciente, desde que não relacionadas com internação anterior no mesmo hospital (ANVISA 1998), e as principais são infecções do trato urinário e trato respiratório. A resistência nestes casos pode ocorrer devido ao uso inadequado dos antimicrobianos, especialmente na automedicação, que leva ao erro na escolha da classe e da dosagem do medicamento. Infecções recorrentes sem tratamento antimicrobiano adequado também podem levar à seleção de cepas resistentes no organismo (RODRÍGUEZ-BAÑO \& NAVARRO 2008).

Nos países desenvolvidos, a distinção entre a disseminação da infecção na comunidade e nas instituições de saúde é muito clara, enquanto que nos países em desenvolvimento esta divisão é menos óbvia, pois pacientes internados são frequentemente alimentados e assistidos por membros da família, e os patógenos comunitários são trazidos para o ambiente do serviço de saúde, e vice-versa. Assim, as barreiras físicas para genes de resistência são escassas, o que aumenta o risco de infecções por cepas multi-resistentes na população em geral (ASM 2009).

Segundo a Sociedade America de Microbiologia (ASM) (2009), modelos de gerenciamento da resistência mostram que, se a colonização por cepas resistentes na comunidade for baixa, o controle da resistência pode ser mais eficiente nos hospitais. No Brasil, a venda de antimicrobianos sem prescrição médica nas farmácias está 
proibida desde 2010, de acordo com a Resolução RDC 44/10 da ANVISA (2010), porém o acesso da comunidade aos hospitais ainda possui poucas restrições, o que pode facilitar o trânsito de cepas multi-resistentes entre esses dois ambientes.

Os genes de resistência em cepas clínicas são amplamente estudados e já foram identificados em diversos tipos de elementos genéticos mobilizáveis, com arranjos genéticos diferenciados. Genes codificadores das $\beta$-lactamases da família CTX-M, por exemplo, podem ser adquiridos por elementos relacionados a bacteriófagos ou por meio de sequências de inserção, bem como podem estar localizados em estruturas mais complexas, como os integrons, e serem mobilizados por plasmídios. Estes elementos têm o potencial de adquirir novos genes e de se disseminar rapidamente para uma variedade de espécies bacterianas, carreando diversos marcadores de resistência aos antimicrobianos (POIREL et al. 2008).

\subsubsection{Disseminação no Ambiente}

Para o controle da resistência antimicrobiana, é necessário compreender a distribuição de seus genes codificadores no ambiente, e também como a ação antrópica afeta esta distribuição. Pesquisas recentes têm estudado a presença de genes codificadores de resistência em isolados de bactérias de fontes não-clínicas, como alimentos e matrizes ambientais, como solo e água de diversas origens. Porém, o papel do ambiente na origem e transmissão da resistência a partir dos alimentos ou pela contaminação da água e plantações é um tema que ainda necessita de investigações apropriadas (PRADO et al. 2008; LORD SOULSBY OF SWAFFHAM PRIOR 2008; ANSARI \& MALIK 2009; LACHMAYR et al. 2009; MOURA et al. 2010; GARCIA-ALVAREZ et al. 2012). 
O ambiente é um importante reservatório de genes de resistência, os quais são geralmente derivados de genes essenciais da célula. Cepas resistentes podem estar em sítios como a pele e o trato gastrointestinal do homem e animais, e no ambiente, especialmente no esgoto, onde antimicrobianos e microrganismos estão presentes em uma alta densidade, o que pode favorecer o surgimento e a disseminação de cepas resistentes (ASM 2009; MOURA et al. 2010; GARCIA-ALVAREZ et al. 2012).

Outro aspecto relevante a ser considerado é que os antimicrobianos são amplamente utilizados no tratamento e na criação de animais e na agricultura. Uma vez que as classes de antimicrobianos aplicados para estes fins são por vezes as mesmas utilizadas no homem, existe uma preocupação a respeito da ocorrência de resistência cruzada nas infecções por patógenos alimentares (CARATTOLI 2008; LORD SOULSBY OF SWAFFHAM PRIOR 2008; WARREN et al. 2008; ASM 2009; GARCIA-ALVAREZ et al. 2012).

Os antimicrobianos são aplicados tanto para o tratamento e profilaxia de infecções dos animais como para fins de estimular seu crescimento, mas esta prática já foi banida para alguns antimicrobianos na Europa, onde programas de vigilância para o uso dos antimicrobianos vem sendo aplicados (BROWN et al. 2006; LORD SOULSBY OF SWAFFHAM PRIOR 2008; ASM 2009; GARCIA-ALVAREZ et al. 2012). No Brasil, o Ministério da Agricultura, Pecuária e Abastecimento (MAPA) estabelece limites para a presença dos antimicrobianos em cada tipo de carne, por meio de Instruções Normativas, sendo que a última divulgada foi a IN ${ }^{\circ} 11$, de 22 de maio de 2012 (MAPA 2012). 
$\mathrm{Na}$ agricultura, muitos sanitizantes e antimicrobianos são utilizados para prevenir a infecção por fungos e bactérias. Um bom exemplo é o da estreptomicina, que é utilizada em larga escala na prevenção de doenças bacterianas em maçãs e peras, assim como é utilizada na medicina humana, o que pode causar impacto na resistência a este antimicrobiano (SCHLÜTER et al. 2007; LORD SOULSBY OF SWAFFHAM PRIOR 2008; ASM 2009; HAWKEY \& JONES 2009).

Em aqüicultura, a aplicação de grandes quantidades de antimicrobianos como tetraciclina e florfenicol pode gerar impacto na saúde humana devido à transferência horizontal de genes de resistência, considerando-se o fluxo das fontes de águas de fazendas, recreacionais, praias e talvez até da água potável (BAQUERO et al. 2008; ASM 2009).

As estações de tratamento de esgoto (ETEs) são a interface entre os dejetos humanos e o solo e ambientes aquáticos, uma vez que recebem e tratam efluentes de diversas origens que contribuem para o ecossistema final encontrado nas estações, incluindo as frações orgânica, química e microbiológica (STALDER et al. 2012). O descarte de antimicrobianos no ambiente também enriquece a população de bactérias multi-resistentes e seus elementos móveis (HAWKEY \& JONES 2009). Além da água do esgoto vinda de instituições de saúde, o esgoto proveniente de outros locais contém matéria orgânica oriunda dos dejetos humanos e animais, sendo, então, uma importante fonte de bactérias clínicas, e um meio extremamente rico para o surgimento e a transmissão de genes de resistência. Isto se dá porque apesar do meio estar enriquecido com matéria orgânica, o que favorece o crescimento bacteriano, há também poluentes (pesticidas, detergentes, antimicrobianos) que desafiam a 
sobrevivência das bactérias, favorecendo adaptações moleculares, como recombinações e aquisições de novos genes. Durante o tratamento do esgoto, a floculação e a formação de biofilme, bem como as atividades metabólicas no aerador e nos clarificadores podem também promover a troca genética por conjugação (BROWN et al. 2006; SCHLÜTER et al. 2007; BAQUERO et al. 2008; PRADO et al. 2008; MOURA et al. 2010; STALDER et al. 2012).

O tratamento e o destino dado ao esgoto são questões primordiais na prevenção da disseminação da resistência. As plantas das estações de tratamento devem prever e validar a eficácia, tanto da remoção de matéria orgânica como dos patógenos, uma vez que os efluentes tratados que serão liberados no ambiente podem comprometer a saúde da população pela contaminação e disseminação de genes de resistência no solo e nas águas de abastecimento e recreacionais. Em amostras de esgoto das cidades de Hong Kong e Shenzhen, os níveis de antimicrobianos foram medidos e os resultados obtidos mostraram que a cefalosporina de terceira geração cefotaxima estava em concentrações acima de $1 \mu \mathrm{g} / \mathrm{mL}$, podendo assim favorecer o crescimento de cepas produtoras de $\beta$-lactamases de espectro estendido (ESBL) (BAQUERO et al. 2008). A remoção de bactérias contendo estruturas de resistência a antimicrobianos é o novo desafio das ETEs, e diversos estudos têm investigado a eficiência de alguns tratamentos, como luz ultra-violeta, reatores de membrana biológica e cloração, e a ineficiência desses tratamentos poderia resultar em rotas de disseminação de bactérias multi-resistentes (PRADO et al. 2008; STALDER et al. 2012). 
Quando o lodo do esgoto tratado, por exemplo, é utilizado como fertilizante na agricultura, há um risco de que tanto antimicrobianos como cepas resistentes contaminem os alimentos. Este risco também existe nos casos de irrigação de plantações com o efluente tratado proveniente do esgoto (ANSARI \& MALIK 2009; ASM 2009; STALDER et al. 2012).

A Figura 1 mostra as principais rotas de transmissão dos genes de resistência entre humanos, animais, alimentos e ambiente, o que ilustra que o controle da disseminação e a prevenção de novos mecanismos de resistência dependem de esforços multidisciplinares.

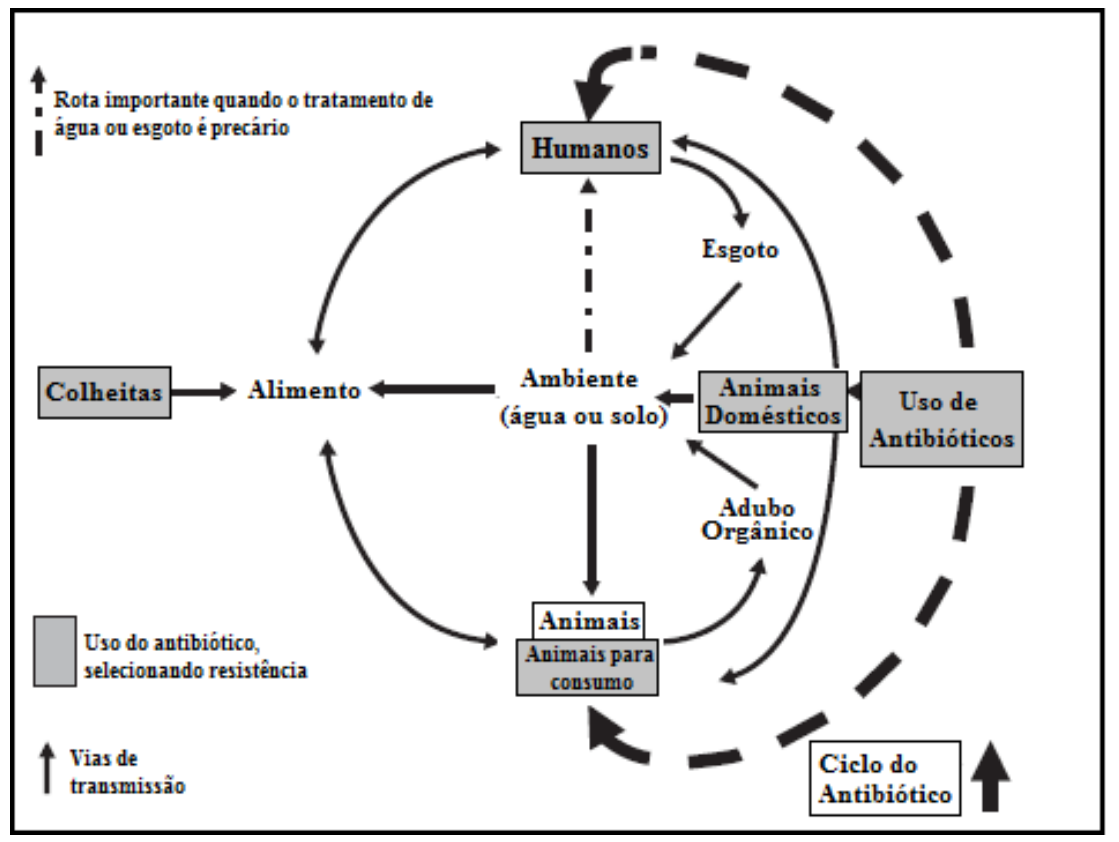

Figura 1. Vias de transmissão da resistência a antimicrobianos entre diversas fontes, adaptada de GARCIA-ALVAREZ et al (2012).

Os genes localizados em elementos móveis no ambiente têm sido pesquisados com freqüência. Comunidades bacterianas provenientes de fontes ambientais têm sido investigadas em relação à vasta diversidade de elementos móveis que podem 
conter, incluindo principalmente plasmídios, integrons e transposons (SCHLÜTER et al 2007; BAQUERO et al. 2008; STALDER et al. 2012). MOURA et al. (2010) determinaram os tipos de plasmídios e integrons presentes em efluentes de esgoto urbano e de matadouros em Portugal. Sete grupos de incompatibilidade plasmidial e três tipos diferentes de integrons foram identificados nos dois tipos de efluentes, demonstrando a riqueza e a variedade desses elementos nos efluentes liberados no ambiente.

A revisão de STALDER et al. (2012) sobre a disseminação de integrons de classe 1 no ambiente revela que adubos orgânicos tratados utilizados na agricultura, ETEs e efluentes industriais são os principais reservatórios para esses elementos disseminadores de resistência, e que os tratamentos utilizados atualmente não são eficientes na redução da disseminação dos mesmos, o que pode representar um risco à saúde humana e animal.

\section{2 $\beta$-Lactâmicos e $\beta$-lactamases}

A classe dos antimicrobianos $\beta$-lactâmicos é a mais utilizada no tratamento e profilaxia de infecções, tanto em ambientes de serviços de assistência à saúde como na comunidade. Infelizmente, o desenvolvimento de resistência a estes antimicrobianos pelas bactérias Gram negativas é rápido, por meio principalmente da produção de enzimas $\beta$-lactamases. O espectro de ação das $\beta$-lactamases pode se modificar e/ou se estender após mutações pontuais em seus genes codificadores, e a substituição e/ou a deleção de um único aminoácido pode originar uma nova enzima (BRADFORD 2001; HAWKEY \& JONES 2009; LACHMAYR et al. 2009). 
As $\beta$-lactamases podem seguir a classificação molecular de Ambler, baseada nas seqüências de nucleotídeos e aminoácidos das enzimas, ou a classificação de Bush \& Jacoby, baseada nas propriedades bioquímicas, estrutura molecular e seqüência nucleotídica das enzimas, separando-as em grupos funcionais (BRADFORD 2001; BUSH \& JACOBY 2010).

Os Quadros 1 e 2 mostram, respectivamente, a classificação dos antimicrobianos $\beta$-lactâmicos e das enzimas $\beta$-lactamases.

Quadro 1. Principais grupos de antimicrobianos $\beta$-lactâmicos (CLSI 2012).

\begin{tabular}{|c|c|l|}
\hline \multicolumn{2}{|c|}{ GRUPO } & \multicolumn{1}{c|}{ EXEMPLOS } \\
\hline \multirow{2}{|c|}{ Penicilinas } & $\begin{array}{l}\text { Ampicilina } \\
\text { Piperacilina } \\
\text { Ticarcilina }\end{array}$ \\
\hline \multirow{4}{*}{ Cefalosporinas } & $\mathbf{1}^{\text {a }}$ Geração & $\begin{array}{l}\text { Cefalotina } \\
\text { Cefazolina }\end{array}$ \\
\cline { 2 - 3 } & \multirow{2}{*}{$\mathbf{2}^{\text {a }}$ Geração } & $\begin{array}{l}\text { Cefuroxima } \\
\text { Cefamandol }\end{array}$ \\
\cline { 2 - 3 } & $\mathbf{3}^{\text {a }}$ Geração & $\begin{array}{l}\text { Ceftazidima } \\
\text { Cefotaxima } \\
\text { Ceftriaxona } \\
\text { Cefoperazona }\end{array}$ \\
\cline { 2 - 3 } & $\mathbf{4}^{\text {a }}$ Geração & Cefepime \\
\hline \multirow{2}{*}{ Cefamicinas } & $\begin{array}{l}\text { Cefoxitina } \\
\text { Cefotetan }\end{array}$ \\
\hline \multicolumn{2}{|c|}{ Monobactâmicos } & Aztreonam \\
\hline \multirow{2}{*}{ Carbapenêmicos } & $\begin{array}{l}\text { Imipenem } \\
\text { Meropenem } \\
\text { Ertapenem } \\
\text { Doripenem } \\
\text { Razupenem }\end{array}$ \\
\hline
\end{tabular}


Quadro 2. Classificação geral das $\beta$-lactamases, adaptada de BUSH \& JACOBY (2010).

\begin{tabular}{|c|c|c|c|c|c|}
\hline \multirow{2}{*}{ AMBLER } & \multirow{2}{*}{$\begin{array}{l}\text { BUSH \& } \\
\text { JACOBY }\end{array}$} & \multirow{2}{*}{ SUBSTRATO } & \multicolumn{2}{|c|}{ INIBIDOR } & \multirow{2}{*}{$\begin{array}{c}\text { Enzimas } \\
\text { Representativas }\end{array}$} \\
\hline & & & $\begin{array}{c}\text { AC ou } \\
\text { TZB }\end{array}$ & EDTA & \\
\hline \multirow[t]{2}{*}{$\mathbf{C}$} & 1 & Cefalosporinas & Não & Não & $\begin{array}{l}\text { E. coli AmpC, } \\
\text { P99, ACT-1, } \\
\text { CMY-2, FOX-1, } \\
\text { MIR-1 }\end{array}$ \\
\hline & $1 \mathrm{e}$ & Cefalosporinas & Não & Não & GC1, CMY-37 \\
\hline \multirow{7}{*}{$\mathbf{A}$} & $2 \mathrm{a}$ & Penicilinas & Sim & Não & $\mathrm{PC} 1$ \\
\hline & \multirow{2}{*}{$\begin{array}{c}2 \mathrm{~b} \\
\text { (ESBL) }\end{array}$} & $\begin{array}{c}\text { Penicilinas e primeiras } \\
\text { Cefalosporinas }\end{array}$ & Sim & Não & $\begin{array}{l}\text { TEM-1, TEM-2, } \\
\text { SHV-1 }\end{array}$ \\
\hline & & $\begin{array}{l}\text { Cefalosporinas de amplo } \\
\text { espectro/Monobactâmicos }\end{array}$ & Sim & Não & $\begin{array}{l}\text { TEM-3, SHV-2, } \\
\text { CTX-M-15, PER- } \\
\text { 1, VEB-1 }\end{array}$ \\
\hline & $2 \mathrm{br}$ & Penicilina & Não & Não & TEM-30, SHV-10 \\
\hline & $\begin{array}{c}\text { 2ber } \\
\text { (ESBL) }\end{array}$ & $\begin{array}{l}\text { Cefalosporinas de amplo } \\
\text { espectro/Monobactâmicos }\end{array}$ & Não & Não & TEM-50 \\
\hline & $2 \mathrm{c}$ & Carbenicilina & Sim & Não & PSE-1, CARB-3 \\
\hline & 2 ce & Carbenicilina/Cefepime & Sim & Não & RTG-4 \\
\hline \multirow{3}{*}{ D } & $2 d$ & Cloxacilina & Variável & Não & OXA-1, OXA-10 \\
\hline & $\begin{array}{c}2 \mathrm{de} \\
\text { (ESBL) }\end{array}$ & $\begin{array}{l}\text { Cefalosporina de amplo } \\
\text { espectro }\end{array}$ & Variável & Não & OXA-11, OXA-15 \\
\hline & $2 \mathrm{df}$ & Carbapenens & Variável & Não & OXA-23, OXA-48 \\
\hline \multirow{2}{*}{$\mathbf{A}$} & $2 \mathrm{e}$ & $\begin{array}{l}\text { Cefalosporina de amplo } \\
\text { espectro }\end{array}$ & Sim & Não & CepA \\
\hline & $2 f$ & Carbapanens & Varável & Sim & $\begin{array}{l}\text { KPC-2, IMI-1, } \\
\text { SME-1 }\end{array}$ \\
\hline B (B1) (B3) & $3 a$ & Carbapenens & Não & Sim & $\begin{array}{l}\text { IMP-1, VIM-1, } \\
\text { CcrA, IND-1 } \\
\text { L1, CAU-1, GOB- } \\
1, \text { FEZ-1 }\end{array}$ \\
\hline B (B2) & $3 b$ & Carbapenens & Não & Sim & CphA, Sfh-1 \\
\hline
\end{tabular}

AC, ácido clavulânico; TZB, tazobactam; EDTA, ácido etilenodiaminotetracético. 


\subsection{1 $\beta$-Lactamases de Espectro Estendido - ESBL}

As ESBL são, por definição, enzimas da classe molecular A (classificação de Ambler), ou das classes 2b, 2ber ou 2de (classificação de Bush \& Jacoby), capazes de hidrolisar cefalosporinas de terceira geração (oximino-cefalosporinas) $10 \%$ a mais do que hidrolisam as benzilpenicilinas. Possuem sítio de ação contendo o aminoácido serina como resíduo catalítico principal, e geralmente são inibidas por compostos como ácido clavulânico (clavulanato), sulbactam e/ou tazobactam. Mutações pontuais que geram substituições, inserções e deleções de aminoácidos na estrutura básica dessas enzimas podem alterar seu espectro de atividade, aumentando sua habilidade de hidrolisar cefalosporinas de terceira e quarta gerações e monobactâmicos (LIVERMORE 2008; BUSH \& JACOBY 2010).

A primeira ESBL foi observada na Europa, em 1983, em uma cepa de Klebsiella ozaenae, e denominada SHV-2 devido à grande homologia observada com os genes bla da $\beta$-lactamase SHV-1, sua precursora (KNOTHE et al. 1983; KLIEBE et al. 1985). As enzimas ESBL do grupo TEM também são derivadas de penicilinases precursoras, neste caso de Escherichia coli, as quais sofreram mutações e foram disseminadas por meio de plasmídios. A distribuição das enzimas ESBL sofreu uma grande mudança nos anos 2000, com a disseminação das CTX-M $\beta$ lactamases, as quais já haviam sido descritas na Argentina dez anos antes, e atualmente são divididas em cinco grupos (clusters): CTX-M-1, CTX-M-2, CTX-M8, CTX-M-9 e CTX-M-25. Os genes codificadores das enzimas CTX-M surgiram a partir de genes cromossômicos de Kluyvera spp e foram mobilizados para plasmídios 
por meio de sequências de inserção (TOLEMAN \& WALSH 2011; CANTÓN et al. 2012).

Desde então, as ESBL tem sido descritas no mundo todo, em diversas espécies da família Enterobacteriaceae e em bacilos Gram negativos não fermentadores de glicose (BRADFORD 2001; GNIADKOWSKI 2008). Na América do Sul, os índices de produção de ESBL em enterobactérias estão entre os mais altos do mundo (PATERSON \& BONOMO 2005; VILLEGAS et al. 2008). As enzimas do grupo SHV foram as primeiras ESBL relatadas, identificadas em isolados clínicos de Klebsiella pneumoniae no Chile e na Argentina (GUTMANN et al. 1989; CASELLAS \& GOLDBERG 1989), enquanto que as ESBL do grupo TEM só foram descritas mais de uma década depois (PATERSON et al. 2003; VIGNOLI et al. 2005). Já as enzimas derivadas da família CTX-M são endêmicas e dominantes nessa região, principalmente as variantes CTX-M-2 e CTX-M-15 (RADICE et al. 2002; CANTÓN \& COQUE 2006; HAWKEY \& JONES 2009).

Os grupos de enzimas CTX-M são predominantes em áreas geográficas distintas. O grupo CTX-M-1, especialmente CTX-M-15, está distribuído mundialmente, com destaque para Europa, América do Norte e Oriente Médio (LIVERMORE 2012). O grupo CTX-M-2 predomina na América Latina, Israel e Japão, o grupo CTX-M-8 foi descrito no Brasil (BONNET et al. 2000) e possui relatos de ocorrência nos Estados Unidos, Europa e África, e a ocorrência do grupo CTX-M-9 foi relatada com frequência na China, Ásia e Espanha (LIVERMORE 2012). 
No Brasil, o índice de enterobactérias produtoras de ESBL é alto, com destaque para as espécies K. pneumoniae (50\%) e E. coli (13\%) (GALES et al. 2012).

As enzimas CTX-M são consideradas endêmicas, e há relatos de todos os grupos, exceto CTX-M-25, em enterobactérias de origem clínica. No grupo das enzimas CTX-M-1, há alguns relatos de cepas produtoras de CTX-M-15 em São Paulo e no Rio de Janeiro (CERGOLLE-NOVELLA et al. 2010; CHAGAS et al. 2011; PEIRANO et al. 2011; TOLLENTINO et al. 2011), enquanto que o grupo CTX-M-2 está disseminado em diversas regiões do país (FERNANDES et al. 2009; PEIRANO et al. 2009; PICÃO et al. 2009; CLÍMACO et al. 2010; LOPES et al. 2010; CHAGAS et al. 2011; TOLLENTINO et al. 2011; QUEIROZ et al. 2012; ZAVASCKI et al. 2012). O grupo CTX-M-8 foi descrito no Brasil por BONNET et al. (2000), em cepas de Enterobacteriaceae isoladas no Rio de Janeiro. Após sua descrição, genes $b l a_{\mathrm{CTX}-\mathrm{M}-8}$ só foram relatados em 2009 em Minas Gerais e em 2011 no Rio de Janeiro, e em ambos os casos foram detectados em cepas de E. coli de origem clínica (MINARINI et al. 2009; PEIRANO et al. 2011). O grupo de enzimas CTX-M-9 também possui poucos relatos no Brasil, apenas em cepas isoladas também na região Sudeste (BONNET et al. 2001; MINARINI et al. 2009; CLÍMACO et al. 2010; CHAGAS et al. 2011; QUEIROZ et al. 2012).

Os grupos TEM e SHV são relatados com menos frequência no Brasil. Aparentemente não há relatos da presença de genes bla $a_{\mathrm{TEM}}$ que codificam enzimas ESBL, isto é, relatos em que a análise da sequência de aminoácidos confirma a presença de uma enzima de espectro estendido. Em relação ao grupo SHV, há duas 
enzimas que foram descritas no Brasil: SHV-27, por Corkill et al. (2001), em uma cepa clínica de $K$. pneumoniae, e SHV-45, em K. pneumoniae isolada em Pernambuco, para a qual não foi identificada uma publicação, apenas sua sequência de nucleotídeos no banco de dados GenBank ( $\mathrm{n}^{\circ}$ de acesso AF547625), depositada em 2002. De acordo com a literatura consultada, não houve mais relatos no Brasil da produção de enzimas SHV-27 e SHV-45 após sua descrição. A enzima SHV-4 foi relatada por MENDES et al. (2004), em uma cepa multi-resistente de $K$. pneumoniae. SHV-5 possui alguns relatos no Brasil, em enterobactérias isoladas no Rio de Janeiro (MULVEY et al. 2004), Minas Gerais (MINARINI et al. 2007, MINARINI et al. 2009) e São Paulo (TOLLENTINO et al. 2011). Em 2011, SHV-28 foi relatada pela primeira vez no Brasil (VERAS et al. 2011), e neste mesmo ano TOLLENTINO et al. (2011) relataram, além de SHV-5, a presença de SHV-2, SHV2a, SHV-12, SHV-31 e SHV-38 em cepas clínicas de K. pneumoniae, em São Paulo.

De acordo com o site www.lahey.org/studies, organizado por BUSH \& JACOBY (c2003), existem 509 ESBL dos grupos SHV (168), TEM (205) e CTX-M (136) descritas e caracterizadas segundo suas diferentes alterações de aminoácidos e sua afinidade por cada substrato. Apesar de haver outros grupos de ESBL com número crescente de variantes, o presente estudo irá abordar esses três grupos principais, uma vez que são mais frequentes em bactérias isoladas no Brasil e na América Latina, conforme citado anteriormente.

Há diversas pesquisas que descrevem a produção de ESBL e outras $\beta$ lactamases em cepas isoladas do ambiente e dos alimentos, demonstrando sua disseminação além dos serviços relacionados à saúde (CARATTOLI 2008; PRADO 
et al. 2008; WARREN et al. 2008; REINTHALER et al. 2010; HARTMANN et al. 2012; DE BOECK et al. 2012; DIWAN et al. 2012). Isto ocorre devido à presença de elementos móveis nas cepas produtoras de ESBL, que facilitam a aquisição e mobilização dos genes $b l a_{\mathrm{ESBL}}$. A maioria desses mecanismos estão relacionados a sequências de inserção, transposons e integrons de classe 1, além de elementos conjugativos que possibilitam sua transferência para outras cepas. Algumas destas estruturas podem mobilizar genes de forma muito fácil e eficiente, enquanto outras são mais complexas devido aos eventos que originaram sua mobilidade (POIREL et al. 2008; TOLEMAN \& WALSH 2011; CANTÓN et al. 2012).

Os genes codificadores de resistência podem estar localizados no DNA cromossômico ou plasmidial das bactérias Gram negativas, e isto está diretamente relacionado ao seu potencial de disseminação entre as cepas. Uma vez localizados em elementos móveis como bacteriófagos, plasmídios conjugativos e mobilizáveis, transposons ou integrons, esses genes podem ser transferidos até para cepas de gêneros e reinos diferentes (CARATTOLI 2009).

\subsubsection{Mobilização dos Genes Codificadores de ESBL}

Os genes codificadores do grupo TEM de $\beta$-lactamases são carreados por transposons das famílias $\operatorname{Tn} 1, \operatorname{Tn} 2$ e $\operatorname{Tn} 3$, sendo que a maioria das estruturas próximas a genes $b l a_{\mathrm{TEM}}$ que codificam ESBLs derivam de uma estrutura $\mathrm{Tn} 3$, enquanto que a aquisição e mobilização de genes bla $a_{\mathrm{SHV}}$ está provavelmente relacionada ao elemento IS26. Genes bla $a_{\mathrm{TEM}}$ e $b l a_{\mathrm{SHV}}$ nunca foram descritos em integrons, devido provavelmente a não possuírem características compatíveis com a formação de cassetes genéticos (PARTRIDGE \& HALL 2005; POIREL et al. 2008). 
Os genes da família CTX-M de ESBLs originam-se de genes bla $a_{\mathrm{KLU}}$ cromossômicos no gênero Kluyvera, presente na microbiota intestinal do homem e na natureza (água, solo, esgoto e alimentos de origem animal). A expressão desses genes cromossômicos é fraca e necessita de um promotor forte na extremidade 5, para que haja um aumento da concentração inibitória mínima (CIM) de antimicrobianos e seja considerada resistente. Estes genes foram mobilizados para plasmídios por meio de transposons, e transferidos horizontalmente para espécies de enterobactérias. A taxa de mobilização de genes $b l a_{\text {CTX-м }}$ para plasmídios é 10 vezes maior que de outros genes codificadores de ESBL. Podem estar associados a diversos elementos genéticos, especialmente as sequências de inserção ISEcpl e ISCRI, as quais além de mobilizar genes bla $a_{\mathrm{CTX}-\mathrm{M}}$ por transposição, também fornecem as sequências promotoras que aumentam os níveis de expressão dos mesmos (CANTÓN \& COQUE 2006; BARLOW et al. 2008; POIREL et al. 2008; TOLEMAN \& WALSH 2011; CANTÓN et al. 2012).

A seguir, considerações gerais sobre os elementos genéticos mais frequentemente relacionados à mobilização dos genes dos grupos de ESBL bla ${ }_{\mathrm{TEM}}$, $b l a_{\mathrm{SHV}}$ e $b l a_{\mathrm{CTX}-\mathrm{M}}$.

\subsubsection{Transposons (Tn)}

Transposons são elementos de DNA capazes de se mover dentro da sequência de DNA onde estão localizados, de um local do DNA para outro, ao que se chama transposição, e as enzimas mediadoras deste mecanismo são as transposases, codificadas pelo gene tnpA. A transposição pode ocorrer também do DNA cromossômico para o plasmidial e vice-versa. Todos os seres vivos possuem 
transposons, porém estes são melhor compreendidos nas bactérias, onde possuem um importante papel na evolução, uma vez que causam inserções, deleções e translocações de DNA no genoma. Todos os transposons contêm genes codificadores das transposases $(\operatorname{tnp} A)$ e repetições invertidas (IRs) em suas extremidades, e podem ser classificados em Sequências de Inserção (IS), Transposons Compostos e Transposons não-Compostos (Figura 2) (SNYDER e CHAMPNESS 1997; MULLANY 2002; TOLEMAN \& WALSH 2011).

As ISs são os menores transposons existentes (750-2000pb), e geralmente codificam apenas as transposases que promovem sua transposição e possuem uma IR em cada extremidade. Quando duas ISs do mesmo tipo se movem e ficam próximas uma da outra, formam um transposon maior, denominado transposon composto, o qual pode conter um cassete de genes entre suas ISs, podendo transpor todo seu conteúdo de um DNA para outro, inclusive do DNA cromossômico para o plasmidial. Como exemplos de transposons compostos, as famílias Tn5 (IS50), Tn9 (IS1) e Tn10 (IS10), que codificam genes de resistência entre as suas ISs. Transposons não-Compostos possuem IRs nas extremidades e genes de resistência a antimicrobianos como parte da unidade mínima de transposição. São exemplos as famílias Tn3 e Tn21 (SNYDER \& CHAMPNESS 1997). A Figura 2 representa esquematicamente as estruturas das ISs e dos transposons. 


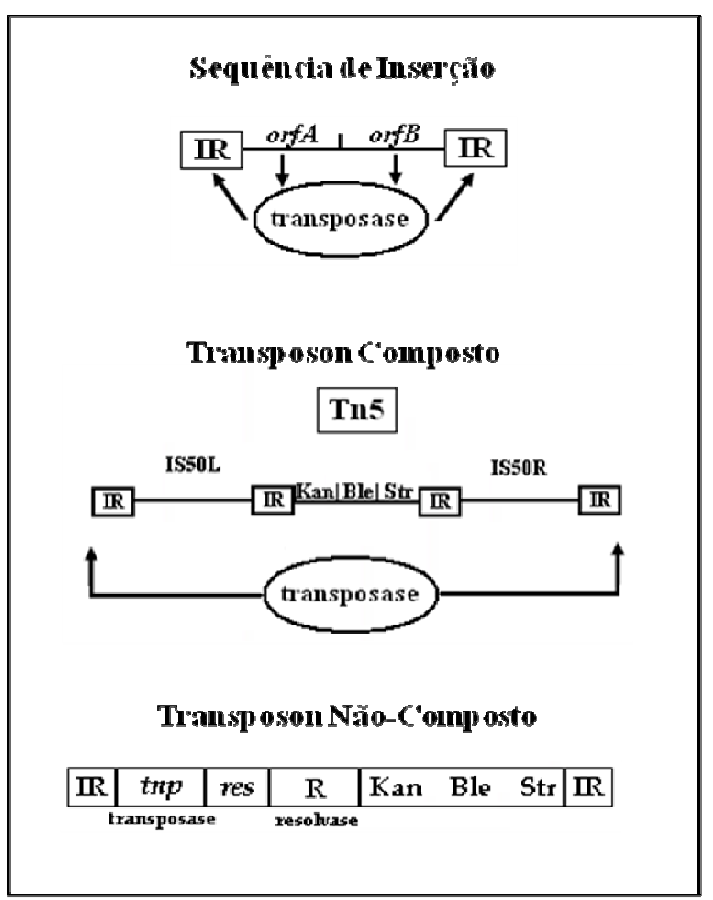

Figura 2. Estrutura esquemática das Sequências de Inserção e Transposons.

A transposição de forma geral ocorre por recombinação não-homóloga, após o pareamento entre duas IRs, excisão do elemento e inserção no novo local da fita de DNA. Todo esse mecanismo é mediado pela transposase, codificada por genes tnpA específicos para cada transposon. Uma vez que este mecanismo gera danos ao DNA, a célula bacteriana aciona mecanismos de reparo, exceto quando o transposon possui o gene da resolvase $(\operatorname{tnp} R)$, a qual reconhece sítios denominados res e faz o reparo na fita danificada, causando menos prejuízos à célula. A frequência em que a transposição ocorre depende da natureza do elemento e da existência ou não de mecanismos regulatórios (SNYDER \& CHAMPNESS 1997; MULLANY 2002).

\section{Transposons $\operatorname{Tn} 1, \operatorname{Tn} 2$ e $\operatorname{Tn} 3$}

Os genes $b l a_{\mathrm{TEM}}$ podem estar localizados em tranposons não-compostos denominados $\operatorname{Tn} 1, \operatorname{Tn} 2$ ou $\operatorname{Tn} 3$, dependendo de qual seja seu gene precursor: $\operatorname{Tn} 3$ se 
evoluiu de $b l a_{\mathrm{TEM}-1 \mathrm{~A}}$, Tn2 se evoluiu de $b l a_{\mathrm{TEM}-1 \mathrm{~B}}$ e Tn 1 se evoluiu de $b l a_{\mathrm{TEM}-2}$. Algumas diferenças entre os três elementos pode ser observada na sequência do gene da resolvase tnpR, na qual o iniciador utilizado neste estudo foi baseado (PARTRIDGE \& HALL 2005; NOVAIS et al. 2010).

Enquanto Tn1 e Tn2 mobilizam-se por recombinação não-homóloga, como descrito anteriormente, o transposon Tn3 possui um mecanismo denominado “imunidade de transposição", no qual a frequência da transposição do Tn3 para um plasmídio diminui quando este já possui uma cópia do Tn3, impedindo que haja mais de duas cópias do elemento no mesmo replicon (LEE et al. 1983; ARTHUR et al. 1984). Assim como algumas sequências de inserção, os transposons da família Tn3 fazem "transposição de extremidade única", ou seja, não conseguem reconhecer uma de suas sequências terminais, e acabam reconhecendo sequências substitutas geneticamente mais distantes. A vantagem deste mecanismo é que o transposon só depende da funcionalidade de uma de suas extremidades, e portanto só necessita de uma cópia na sequência, ao invés de duas. Assim, a chance do elemento se mover para uma posição adjacente a um gene de resistência é muito maior, e uma vez próximos um do outro, o gene será mobilizado juntamente com o Tn3 nos demais eventos de transposição. Além do Tn3, os elementos ISEcpl e ISCR1 também realizam transposição de extremidade única (ARTHUR et al. 1984; TOLEMAN \& WALSH 2011).

\section{Sequências de Inserção ISEcp1, ISCR1, IS10 e IS26}

Em 2001, a sequência de inserção ISEcpl foi identificada pela primeira vez próxima a um gene de resistência ( $\left.b l a_{\mathrm{CTX}-\mathrm{M}-15}\right)$, e encontra-se disseminada no mundo 
todo. Há evidências de que seja responsável pela mobilização de genes dos grupos $b l a_{\mathrm{CTX}-\mathrm{M}-1}, b l a_{\mathrm{CTX-M-2}}$ e $b l a_{\mathrm{CTX-M-9}}$, além de genes codificadores de AmpC $\beta$ lactamases e resistência a quinolonas $(q n r B 19)$ e aminoglicosídeos $(r m t C)$. A localização da ISEcpl próxima à extremidade 5 , dos genes bla $a_{\mathrm{CTX}-\mathrm{M}}$ torna a expressão dos mesmos maior devido à presença de seu promotor $\mathrm{P}_{\text {out }}$, sugerindo que a localização da IS tenha um papel importante na seleção e disseminação das CTXMs. Além disso, a distância entre a ISEcpl e o gene $b l a_{\mathrm{CTX}-\mathrm{M}}$ está relacionada à concentração inibitória mínima das cefalosporinas. A transposição da ISEcpl ocorre de forma muito semelhante ao Tn3, em duas etapas: após se transpor para uma região próxima a um gene de resistência, realiza a transposição de extremidade única, mobilizando o gene (TOLEMAN \& WALSH 2011; CANTÓN et al. 2012).

A ISCR1 foi descrita primeiramente como uma região comum (CR) ou como a região aberta de leitura orf513 identificada como parte de alguns integrons, hoje denominados integrons de classe 1 complexos, descritos posteriormente. Atualmente há 23 ISCRs descritas, e todas foram descobertas muito próximas a genes de resistência adquiridos por transferência horizontal (TOLEMAN et al. 2006; TOLEMAN \& WALSH 2011).

A ISCR 1 possui uma maior habilidade de mobilização que ISEcp 1, devido ao seu mecanismo de transposição que envolve transposição de extremidade única e replicação por círculo rolante, um mecanismo peculiar que envolve replicação e recombinação do elemento após sua circularização, e permite que uma região mais extensa de DNA seja mobilizada (28 kb ou mais) (CANTÓN \& COQUE 2006; POIREL et al. 2008; TOLEMAN \& WALSH 2011; CANTÓN et al. 2012). 
A IS10 faz parte do transposon composto Tn10, e pode mobilizar tanto o elemento Tn10 completo como parte dele, atuando apenas como uma sequência de inserção individual. Pode também fazer parte de elementos auto-replicativos e autoconjugativos denominados elementos integrativos-conjugativos (ICE). A frequência da transposição da IS10 é baixa e estritamente regulada por mecanismos celulares que reduzem a expressão da transposase. Porém, essa frequência pode aumentar devido à influência de fatores externos que estimulam a resposta SOS da célula, como incubação contínua na fase estacionária e a irradiação de luz ultra-violeta (EICHENBAUM \& LIVNEH 1998; TOLEMAN \& WALSH 2011).

IS26 foi um dos primeiros elementos relacionados à aquisição de genes de resistência. Necessita de duas cópias na sequência de DNA para realizar a transposição, o que não a impede de se mobilizar muitas vezes já que não apresenta mecanismos regulatórios e portanto possui muitas cópias ao longo do genoma (TOLEMAN \& WALSH 2011).

IS26 foi o elemento responsável pelos dois eventos de captura e mobilização cromossomo-plasmídio que ocorreram com os genes bla $a_{\mathrm{SHV}}$ em Klebsiella pneumoniae. O primeiro evento deu origem a uma estrutura denominada "grande transposon", comum nas variantes SHV-1, -2 e -5, a qual possui um promotor forte devido a algumas mutações em sua sequência. O segundo evento de mobilização mediado pela IS26 gerou a estrutura denominada "pequeno transposon", comum para genes $b l a_{\mathrm{SHV}-2 \mathrm{a}}, b l a_{\mathrm{SHV}-11}$ e $b l a_{\mathrm{SHV}-12}$, e que possui um promotor forte gerado pela inserção da IS26 dentro da sua sequência. Dessa forma, as estruturas resultantes destes eventos possuem promotores fortes frequentemente identificados em 
plasmídios, tanto de K. pneumoniae como outras Enterobacteriaceae, o que sugere que a localização de genes bla $a_{\mathrm{SHV}}$ em cepas que expressam o fenótipo ESBL seja plasmidial, uma vez que a expressão do gene no cromossomo não seria suficiente para resultar neste fenótipo (HAMMOND et al. 2008; TURNER et al. 2009). É importante observar que, para que a IS26 realizasse estes eventos, ela teria que estar no genoma da Klebsiella, onde provavelmente chegou por meio de um plasmídio do ambiente. A presença da IS26 em Klebsiella no ambiente permite a movimentação genética entre bactérias ambientais e clínicas, aumentando o potencial de disseminação deste elemento (TOLEMAN \& WALSH 2011).

Além da mobilização de genes bla $a_{\mathrm{SHV}}$, a IS26 também está associada à mobilização de genes $b l a_{\mathrm{CTX}-\mathrm{M}}$, porém em menor frequência que ISEcpl e ISCR1. Apesar disso, é importante notar que as diversas posições da inserção de IS26 sugerem rearranjos frequentes dentro do ambiente genético das Enterobacteriaceae. É comum observar, por exemplo, a IS26 interrompendo a sequência de ISEcpl que precede genes bla $a_{\mathrm{CTX}-\mathrm{M}}$ (TOLEMAN \& WALSH 2011; CANTÓN et al. 2012; SHAHID et al. 2012).

\subsubsection{Integrons (In)}

Integrons são elementos que incorporam cassetes genéticos por recombinação sítio-específica e os converte em genes funcionais garantindo sua expressão correta, por possuírem promotores. Fornecem às bactérias um sistema de captura de genes perfeitamente adaptado aos desafios impostos pelos tratamentos com antimicrobianos (MAZEL 2006). 
Os integrons podem ser divididos em móveis e imóveis. Os integrons móveis pertencem às classes 1 a 5, e os imóveis são os denominados super-integrons. Porém, mesmo classificados como móveis, os integrons das classes 1 a 5 não são capazes de se mobilizar sozinhos, para isso necessitam estar ligados a outros elementos móveis para que ocorra a transmissão de material genético intra e inter-espécies (MAZEL 2006).

São compostos por duas regiões conservadas (5'CS e $\left.3^{\prime} \mathrm{CS}\right)$ e uma região variável entre elas, geralmente contendo genes de resistência (FLUIT \& SCHMITZ 2004; MAZEL 2006). A região 5'CS é composta pelo gene intIl codificando uma integrase da família das tirosina-recombinases, um sítio de recombinação primária attI, e uma região contendo o promotor $\mathrm{P}_{\text {ant }}$. $\mathrm{O}$ promotor $\mathrm{P}_{\text {ant }}$ é constituído por duas sequências de seis bases nas posições -35 e -10, respectivamente, e é responsável pelo direcionamento da transcrição dos cassetes gênicos inseridos entre as regiões conservadas. Pode haver também um segundo promotor, localizado $119 \mathrm{pb}$ após $\mathrm{P}_{\mathrm{ant}}$ (MAZEL 2006).

A região conservada 3'CS é composta pelos genes qacE 11 e sull conjugados, codificando respectivamente resistência a compostos de amônio quaternário e sulfonamidas, e por duas regiões abertas de leitura (open reading frames - orf), orf5 e orf6, de função desconhecida (MAZEL 2006; PARTRIDGE et al. 2009).

A região variável dos integrons pode apresentar diversos cassetes gênicos, que são inseridos e extraídos pela integrase IntI1. Estes cassetes possuem tamanho variável (500-1000pb) e são constituídos por dois componentes funcionais: o(s) gene(s) codificando alguma proteína, e um sítio de recombinação 59-be (elementos 
de base), que é uma repetição invertida (IR) imperfeita e variável na extremidade 3' do gene, também denominada região $a t t C$. Os cassetes normalmente dependem do promotor contido no integron para serem transcritos e expressos (FLUIT \& SCHMITZ 2004; MAZEL 2006; PARTRIDGE et al. 2009). A Figura 3 representa esquematicamente a estrutura de um integron de classe 1.

A integrase IntI1 é uma recombinase sítio-específica cujos dois sítios preferenciais de ação se situam na região attC do cassete gênico e em attIl do integron, podendo promover a recombinação de sequências não relacionadas de DNA. Promove a mobilização dos cassetes genéticos que estão dentro do integron por meio da excisão, circularização e reintegração dos mesmos. A recombinação pode ocorrer, em ordem decrescente de eficiência, principalmente entre attI x attC, $a t t C \times$ attC ou attI x attI, e este processo pode gerar deleções, duplicações e rearranjos dos cassetes genéticos nos integrons (FLUIT \& SCHMITZ 2004; MAZEL 2006).

Os integrons de classe 1 são funcionais e amplamente identificados em isolados clínicos, e a maioria dos cassetes de resistência a diversas classes de antimicrobianos pertencem a este grupo (MAZEL 2006; PARTRIDGE et al. 2009).

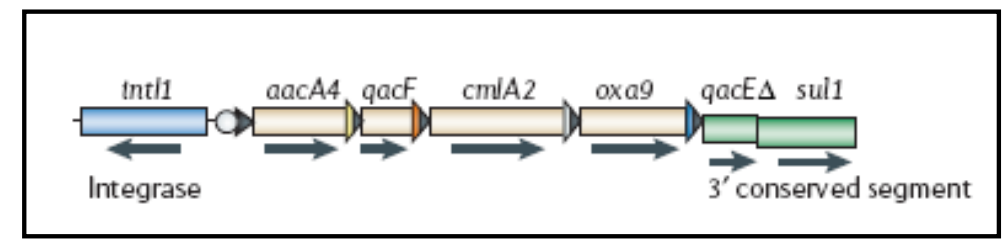

Figura 3. Representação esquemática do integron de classe 1 In40 (MAZEL 2006). 


\section{Integrons de Classe 1 Complexos}

Integrons de Classe 1 Complexos surgiram após alguns eventos de recombinação e mobilização que resultaram na fusão da sequência de inserção ISCR1 com a porção 3'CS do integron de classe 1. A ISCR1 se transpôs para uma posição próxima à extremidade 3' da porção qacEA1sull, ocasionando a deleção das regiões abertas de leitura orf5 e orf6 e da porção terIS, responsável pelo término da replicação por círculo rolante (TOLEMAN \& WALSH 2011).

Isto resultou em um elemento que, além de adquirir cassetes genéticos de resistência integrando os mesmos em sua região variável por meio de recombinação sítio-específica, se tornou móvel devido à presença da ISCR1, a qual como já mencionado pode mover pelo menos $28 \mathrm{~kb}$ da sequência adjacente a ela graças à sua forma de mobilização, e que neste caso em que houve a deleção da região terIS permite que a replicação por círculo rolante seja contínua através da estrutura do integron de classe 1, mobilizando-a (ou parte dela) portanto com maior frequência (TOLEMAN \& WALSH 2011; CANTÓN et al. 2012; STALDER et al. 2012).

$\mathrm{Da}$ forma como ficaram posicionados, esses elementos geram formas circulares que incluem a região $3^{\prime} \mathrm{CS}$, o integron de classe 1 e o recém adquirido gene de resistência, e estas formas circularizadas podem ser resgatadas por

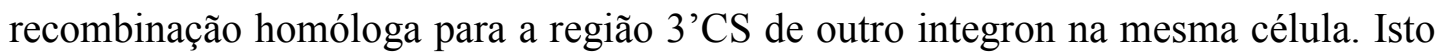
resulta em integrons de classe 1 complexos contendo repetições diretas de 3'CS e um gene de resistência não derivado de um cassete posicionado entre as repetições, configurando portanto uma nova forma de aquisição de genes (Figura 4) (POWER et al. 2005; TOLEMAN \& WALSH 2011). 
Em relação às ESBL, os integrons de classe 1 complexos já foram associados com genes dos grupos $b l a_{\mathrm{CTX-M-1}}, b l a_{\mathrm{CTX-M-2}}$ e $b l a_{\mathrm{CTX-M-9}}$, justificando de mais uma forma a disseminação mundial dos mesmos, com destaque para o relato destes elementos em diversos trabalhos da América Latina (POWER et al. 2005; VIGNOLI et al. 2006; QUIROGA et al. 2007; BAE et al. 2008).

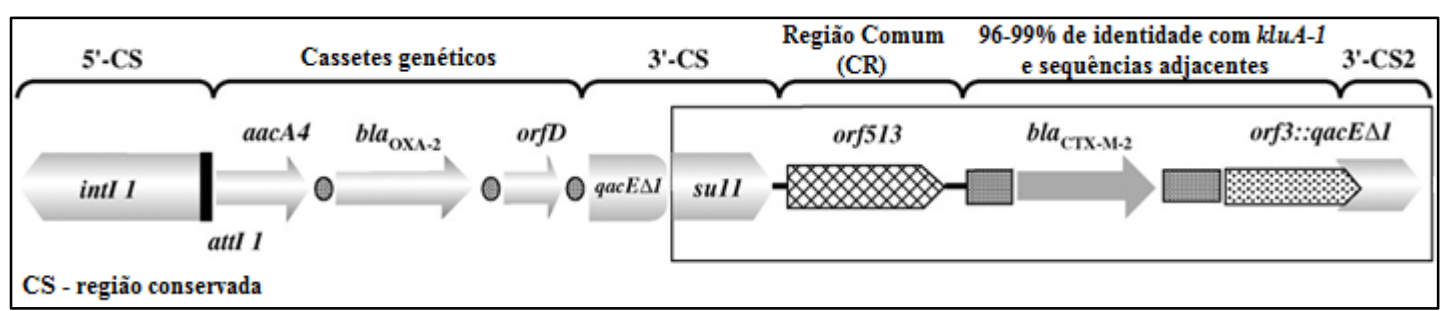

Figura 4. Representação esquemática do Integron de Classe 1 Complexo, adaptada de POWER et al. (2005).

\subsubsection{Plasmídios}

Enterobactérias possuem frequentemente elementos genéticos extracromossômicos auto-replicativos denominados plasmídios. São moléculas de DNA circular dupla fita que não carregam genes essenciais para o crescimento das células hospedeiras sem que haja situações de estresse. Possuem sistemas tanto para assegurar sua auto-replicação como para controlar seu número de cópias na célula. Muitos plasmídios possuem também sistemas toxina-antitoxina que matam célulasfilhas que não herdam suas cópias na divisão celular (CARATTOLI 2009).

Os plasmídios podem, por meio da conjugação, ser transferidos horizontalmente para outras células, inclusive de outros gêneros e até de outros reinos. A conjugação é um mecanismo sofisticado e eficiente que necessita de um maquinário que envolve um grande conjunto de genes. Plasmídios que codificam o maquinário protéico completo para a conjugação são denominados conjugativos ou 
auto-transmissíveis. Porém, alguns plasmídios possuem apenas parte dos genes necessários para a transferência, o que permite a eles serem transmitidos por conjugação apenas na presença de um plasmídio conjugativo, e são denominados plasmídios mobilizáveis (Figura 5). Tanto plasmídios conjugativos como mobilizáveis representam um grande impacto na transferência horizontal de genes na natureza, incluindo a disseminação da resistência a antimicrobianos (FROST et al. 1994; FRANCIA et al. 2004; ZAHRL et al. 2007; CARATTOLI 2009; GARCILLÁN-BARCIA et al. 2009).

Os plasmídios conjugativos são grandes $(>30 \mathrm{~kb})$, pois carregam genes que codificam todo o sistema de transferência horizontal, sendo compostos essencialmente por uma origem de replicação oriV (genes oriV), uma origem de transferência oriT (genes oriT), e pelas proteínas do sistema Tra (genes tra), formadoras do pilus conjugativo, do canal de transferência e da enzima relaxase (SNYDER \& CHAMPNESS 1997; GARCILLÁN-BARCIA et al 2009).

A região oriT normalmente possui uma repetição invertida (IR) e é por onde se inicia toda transferência por conjugação. O sistema Tra é um sistema de secreção do tipo IV. É um operon, composto de muitos genes tra para a transcrição de um grande sistema protéico, a partir da ativação pelo gene traJ (FROST et al. 1994; ZAHRL et al. 2007; GARCILLÁN-BARCIA et al 2009).

O mecanismo da conjugação se inicia com a secreção das proteínas do pilus, que é utilizado para aproximar a célula doadora da receptora. Forma-se então o canal protéico de ligação entre as células e o processo de transferência se inicia. A relaxase é a enzima essencial à conjugação, pois reconhece a região oriT de seu próprio 
plasmídio, clivando-a e permanecendo ligada covalentemente à sua extremidade 5'. A relaxase é então reconhecida pela proteína acopladora tipo IV (T4CP), que transporta ativamente o complexo relaxase-plasmídio fita simples (relaxossoma) pelo canal protéico para a célula receptora. A relaxase une as extremidades da fita simples e se desliga. Tanto a fita simples que restou na célula doadora como a que foi transferida para a célula receptora são então replicadas e cada célula fica com uma cópia do plasmídio (FROST et al. 1994; GARCILLÁN-BARCIA et al 2009).

Plasmídios mobilizáveis são pequenos $(<15 \mathrm{~kb})$, compostos apenas por origem de replicação oriV (genes oriV), origem de transferência oriT (genes oriT), e pela enzima relaxase, além de outras proteínas acessórias (genes mob). Como codificam sua própria relaxase, o mecanismo a partir da clivagem da região oriT é o mesmo descrito acima, porém para o transporte do complexo relaxossoma, os plasmídios mobilizáveis necessitam utilizar o sistema montado pelo plasmídio conjugativo, cuja proteína acopladora reconhece ambas as relaxases, e o transporte ativo do complexo ocorre normalmente. Assim, tanto o plasmídio mobilizável como o conjugativo são transferidos e replicados (FRANCIA et al. 2004; GARCILLÁNBARCIA et al 2009).

O mecanismo de replicação ocorrido na transferência plasmidial descrita acima é conhecido como Círculo Rolante (Rolling Circle), porém é importante lembrar que plasmídios conjugativos e mobilizáveis possuem a origem de replicação oriV e podem, dentro de sua célula hospedeira, fazer a replicação convencional do tipo Teta $(\theta)$, além de poder também iniciar a replicação por meio de iniciadores RNA ao invés de proteínas (FROST et al. 1994; GARCILLÁN-BARCIA et al 2009). 


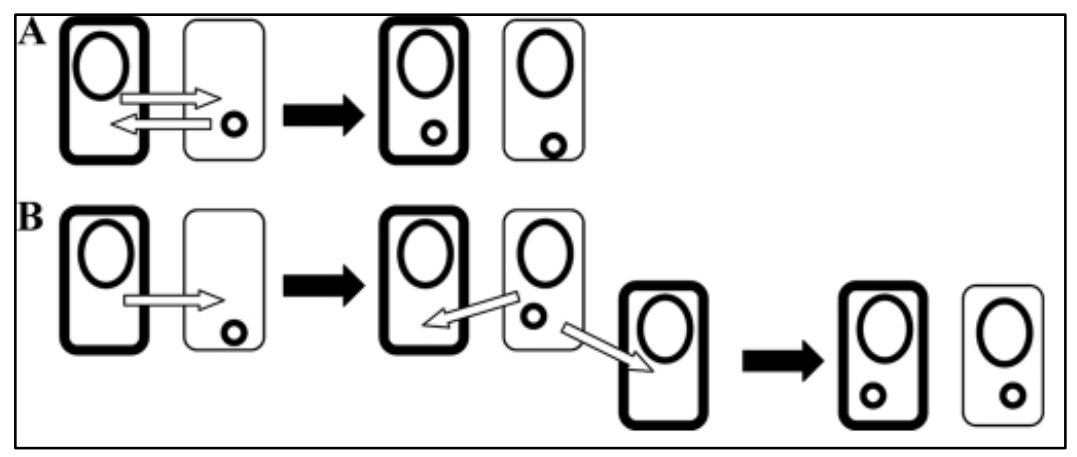

Figura 5. Representação esquemática dos tipos de mobilização plasmidial. A - a transferência do plasmídio conjugativo (maior) ocorre simultaneamente com a do plasmídio mobilizável (menor); B - a transferência do plasmídio conjugativo ocorre em um primeiro evento, e a do plasmídio mobilizável em eventos posteriores. Adaptada de Timmery et al. (2009).

\section{Grupos de Incompatibilidade Plasmidial (Inc)}

A incompatibilidade entre plasmídios é a impossibilidade de dois plasmídios relacionados se propagarem de forma estável na mesma linhagem celular por possuírem sistemas de replicação semelhantes. A partir desta característica, os plasmídios foram classificados em grupos de incompatibilidade (Inc), uma vez que dois plasmídios do mesmo grupo Inc não coexistem na mesma célula ou linhagem bacteriana. Os primeiros grupos Inc definidos foram IncI, IncN, IncF e IncP, e na família Enterobacteriaceae há 27 grupos Inc reconhecidos, dentre eles seis variantes de IncF, e três variantes de IncI (CARATTOLI 2009).

Os plasmídios dos grupos IncFII, IncA/C, IncL/M e IncI1 são os mais frequentes entre plasmídios de resistência a antimicrobianos, podendo ser considerados epidêmicos, uma vez que foram detectados em bactérias de diferentes origens, isoladas de diversos países. A ocorrência desses plasmídios está aparentemente ligada à pressão seletiva exercida pelo uso de antimicrobianos, pois 
sua prevalência é menor em bactérias que não foram expostas a estes compostos. Em relação às ESBL, genes $b l a_{\mathrm{SHV}}$ e bla $a_{\mathrm{CTX}-\mathrm{M}}$ estão mais associados com os grupos IncF, IncA/C, IncL/M, IncI1 e IncH12 (CARATTOLI 2009).

A partir dos grupos Inc, foram propostos esquemas de tipagem plasmidial baseados em replicons (regiões de replicação clonadas), primeiramente utilizando Southern Blot e hibridização, que subestimou a diversidade plasmidial devido a reações cruzadas de hibridização entre replicons altamente relacionados, e posteriormente utilizando a reação em cadeia pela polimerase (PCR), em uma técnica denominada PCR-based replicon typing, PBRT, padronizada para os grupos Inc de Enterobacteriaceae e utilizada nas pesquisas desde então (CARATTOLI et al. 2005; CARATTOLI 2009; NOVAIS et al. 2010; QUEIROZ et al. 2012). A limitação desta técnica é que os plasmídios podem carregar múltiplos replicons ou apresentar mosaicismo nos mesmos, além de se aplicar apenas aos replicons dos principais grupos de incompatibilidade plasmidial das enterobactérias (CARATTOLI et al. 2005; GARCILLÁN-BARCIA et al. 2009).

Considerando, portanto, as evidências de que genes de resistência que codificam ESBLs estão presentes em estruturas genéticas complexas e altamente mobilizáveis, e que estão disseminados em bactérias Gram negativas presentes em diversos tipos de ambientes, este estudo propôs a investigação da presença desses genes e estruturas móveis em cepas de origem clínica e ambiental, em uma tentativa de visualizar quais seriam os genes carreados por essas cepas, e também quais as prováveis formas de mobilização e disseminação dos mesmos nos diferentes ambientes. 


\section{OBJETIVOS}

\subsection{Objetivo Geral}

Identificar e caracterizar genes codificadores de $\beta$-lactamases de espectro estendido, bem como suas prováveis formas de mobilização, em enterobactérias isoladas de fontes ambientais e clínicas.

\subsection{Objetivos Específicos}

- Selecionar, a partir do banco de cepas do Laboratório de Prática de Saúde Pública da USP, cepas de enterobactérias produtoras de ESBL das famílias TEM, SHV e CTX-M geneticamente distintas, isoladas de um hospital público e de estações de tratamento de esgoto da Grande São Paulo;

- Identificar, por PCR e análise de sequenciamento, os genes codificadores de ESBL $b l a_{\mathrm{TEM}}, b l a_{\mathrm{SHV}}$ e $b l a_{\mathrm{CTX}-\mathrm{M}}$ presentes nas cepas selecionadas;

- Determinar o ambiente genético adjacente aos genes detectados, bem como sua provável forma de mobilização. 


\section{MATERIAL E MÉTODOS}

\subsection{Cepas Bacterianas}

As cepas estudadas no presente trabalho fazem parte da família Enterobacteriaceae e pertencem à coleção de cultura do Laboratório de Prática de Saúde Pública da Faculdade de Saúde Pública da Universidade de São Paulo.

Foram analisadas 135 cepas clínicas isoladas em 2004/2005, provenientes de infecções relacionadas à assistência à saúde, infecções comunitárias ou colonizações (DROPA 2006, DROPA et al. 2009), e 200 cepas ambientais, isoladas em 2009 de esgoto e lodo brutos ou tratados, de Estações de Tratamento de Esgoto (ETE) da Grande São Paulo (Projeto Finep/CNPq "Detecção e genotipagem de Aeromonas, Cryptosporidium e Giardia em amostras ambientais").

As 335 cepas foram submetidas ao teste de suscetibilidade a antimicrobianos $\beta$-lactâmicos (Ampicilina, Cefalotina, Cefoxitina, Cefotetan, Ceftazidima, Cefotaxima, Cefepime, Aztreonam, Meropenem e Ertapenem) por disco-difusão, e aquelas que apresentavam resistência às cefalosporinas de $3^{\mathrm{a}}$ e $4^{\mathrm{a}}$ geração e/ou aztreonam foram analisadas quanto à produção fenotípica de ESBL, pelo método de aproximação de discos (BRADFORD 2001; CLSI 2012). Das 335 cepas, 142 eram produtoras de ESBL (135 clínicas e 7 ambientais), e foram submetidas à medida da concentração inibitória mínima $(\mathrm{CIM})$ para $\beta$-lactâmicos pelo método Etest ${ }^{\circledR}$ (Tabela 1), e à genotipagem por eletroforese em campo pulsado (PFGE), para possibilitar a eliminação de clones (DROPA 2006; DROPA et al. 2009). 
Após as análises descritas acima, foram selecionadas 52 cepas produtoras de ESBL com perfis genéticos distintos. São 45 cepas clínicas, provenientes de infecções hospitalares $(n=14)$, infecções comunitárias $(n=7)$ e colonizações $(n=24)$, e 7 cepas ambientais, provenientes de cinco Estações de Tratamento de Esgoto da Grande São Paulo (Tabela 1). 
Tabela 1. Características das cepas clínicas e ambientais produtoras de ESBL selecionadas para o estudo.

Cepas Clínicas (n=45) - Julho/2004 a Julho/2005

\begin{tabular}{|c|c|c|c|c|c|c|c|c|c|c|c|c|c|}
\hline \multicolumn{14}{|c|}{ Infecções Hospitalares $(n=14)$} \\
\hline \multirow[t]{2}{*}{ ID FSP } & \multirow[t]{2}{*}{ Espécie } & \multirow[t]{2}{*}{ Local } & \multirow[t]{2}{*}{ Amostra } & \multicolumn{10}{|c|}{ CIM $(\mu \mathrm{g} / \mathrm{mL})$} \\
\hline & & & & FOX & CTT & CAZ & CTX & АTM & FEP & AMC & PIP & MEM & ERT \\
\hline 209/05 & Morganella morganii & Clínica Médica & Urina & $>256$ & 8 & 2 & $>256$ & $>256$ & $>256$ & $>256$ & 1,5 & 0,125 & 0,047 \\
\hline $211 / 05$ & Klebsiella pneumoniae & Clínica Médica & Sangue & 6 & 0,25 & 6 & 64 & 12 & 32 & 3 & 2 & 0,125 & 0,19 \\
\hline $224 / 05$ & Klebsiella pneumoniae & UTI Neonatal & Secreção Ocular & 3 & 0,38 & 96 & 12 & $>256$ & 12 & 6 & 192 & 0,023 & 0,094 \\
\hline $225 / 05$ & Klebsiella pneumoniae & Berçário & Sangue & 4 & 0,38 & 128 & 8 & 96 & 1,5 & 6 & 12 & 0,032 & 0,047 \\
\hline $226 / 05$ & Klebsiella pneumoniae & UTI Neonatal & Secreção Ocular & 3 & 0,25 & $>256$ & 6 & $>256$ & 12 & 6 & 8 & 0,032 & 0,125 \\
\hline $237 / 05$ & Klebsiella pneumoniae & Semi-UTI & Urina & 3 & 0,125 & 24 & $>256$ & $>256$ & 64 & 12 & 4 & 0,032 & 0,25 \\
\hline $246 / 05$ & Escherichia coli & Ambulatório & Urina & 6 & 0,19 & 6 & $>256$ & $>256$ & $>256$ & 6 & 2 & 0,023 & 0,047 \\
\hline $262 / 05$ & Klebsiella pneumoniae & Berçário & Urina & 3 & 0,38 & 256 & 24 & $>256$ & 2 & 4 & 32 & 0,023 & 0,19 \\
\hline $287 / 05$ & Klebsiella pneumoniae & UTI Neonatal & Líq. Peritonial & 2 & 1,5 & $>256$ & $>256$ & $>256$ & 32 & 8 & $>256$ & 0,047 & 0,25 \\
\hline $306 / 05$ & Escherichia coli & Clínica Cirúrgica & Urina & 4 & 0,25 & 48 & 6 & 64 & 0,75 & 8 & 2 & 0,023 & 0,023 \\
\hline $309 / 05$ & Providencia rettgeri & PS & Urina & 8 & 0,38 & 6 & 256 & 6 & 64 & 128 & 1,5 & 0,094 & 0,094 \\
\hline $318 / 05$ & Providencia stuartii & UTI & $\mathrm{LBA}^{\mathrm{a}}$ & 24 & 0,38 & 2 & 48 & 4 & 64 & 48 & 6 & 0,094 & 0,094 \\
\hline $326 / 05$ & Escherichia coli & UTI & $\mathrm{LBA}^{\mathrm{a}}$ & 6 & 0,38 & 2 & $>256$ & 12 & 24 & 6 & 3 & 0,023 & 0,047 \\
\hline $328 / 05$ & Escherichia coli & UTI & $\mathrm{LBA}^{\mathrm{a}}$ & 6 & 0,19 & 4 & $>256$ & 32 & 192 & 6 & 4 & 0,016 & 0,023 \\
\hline \multicolumn{14}{|c|}{ Infecções Comunitárias (n=7) } \\
\hline \multirow[t]{2}{*}{ ID FSP } & Espécie & Local & Amostra & \multicolumn{10}{|c|}{ CIM $(\mu \mathrm{g} / \mathrm{mL})$} \\
\hline & & & & FOX & CTT & $\mathrm{CAZ}$ & CTX & ATM & FEP & AMC & PIP & MEM & ERT \\
\hline $214 / 05$ & Klebsiella pneumoniae & Ambulatório & Urina & 3 & 0,19 & $>256$ & 3 & $>256$ & 2 & 4 & 2 & 0,023 & 0,023 \\
\hline $234 / 05$ & Klebsiella pneumoniae & Ambulatório & Urina & 16 & 0,75 & 4 & $>256$ & 128 & 256 & 6 & 12 & 0,094 & 0,75 \\
\hline $314 / 05$ & Escherichia coli & PS & Urina & 8 & 0,38 & 8 & $>256$ & $>256$ & $>256$ & 8 & 12 & 0,047 & 0,19 \\
\hline $315 / 05$ & Klebsiella pneumoniae & PS & Urina & 4 & 0,19 & $>256$ & 12 & $>256$ & 3 & 8 & 128 & 0,023 & 0,032 \\
\hline $317 / 05$ & Klebsiella pneumoniae & PS & Sangue & 24 & 1,5 & $>256$ & $>256$ & $>256$ & $>256$ & 12 & $>256$ & 0,125 & 0,5 \\
\hline $324 / 05$ & Klebsiella oxytoca & UTI & Líq. Ascítico & 48 & 2 & 32 & $>256$ & 192 & $>256$ & 12 & $>256$ & 0,064 & 0,38 \\
\hline $325 / 05$ & Morganella morganii & PS & Urina & 96 & 3 & 0,5 & 256 & 4 & 0,75 & 64 & 0,75 & 0,064 & 0,012 \\
\hline
\end{tabular}

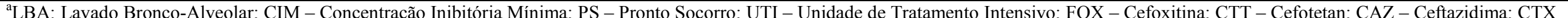

- Cefotaxima; ATM - Aztreonam; FEP - Cefepime; AMC - Amoxicilina+Clavulanato; PIP - Piperacilina+Tazobactam; MEM - Meropenem; ERT - Ertapenem. 
Material e Métodos

\begin{tabular}{|c|c|c|c|c|c|c|c|c|c|c|c|c|c|}
\hline \multirow[t]{2}{*}{ ID FSP } & \multirow[t]{2}{*}{ Espécie } & \multirow[t]{2}{*}{ Local } & \multirow[t]{2}{*}{ Amostra } & \multicolumn{10}{|c|}{ CIM $(\mu \mathrm{g} / \mathrm{mL})$} \\
\hline & & & & FOX & CTT & CAZ & CTX & ATM & FEP & AMC & PIP & MEM & ERT \\
\hline $201 / 05$ & Proteus mirabilis & Semi-UTI & Prega Inguinal & 4 & 0,25 & 1,5 & $>256$ & 8 & $>256$ & 4 & 0,38 & 0,032 & 0,032 \\
\hline $202 / 05$ & Klebsiella pneumoniae & Semi-UTI & Prega Inguinal & 4 & 0,125 & 3 & 32 & 12 & 0,094 & 6 & 8 & 0,023 & 0,016 \\
\hline $205 / 05$ & Escherichia coli & UTI & Escara & 16 & 2 & 25 & $>256$ & 96 & $>256$ & 6 & $>256$ & 0,023 & 0,38 \\
\hline $208 / 05$ & Klebsiella pneumoniae & UTI & Secreção Traqueal & 3 & 0,19 & 8 & 128 & 32 & 64 & 8 & 6 & 0,047 & 0,19 \\
\hline $220 / 05$ & Klebsiella pneumoniae & PS & Urina & 12 & 3 & 8 & $>256$ & 96 & 256 & 12 & $>256$ & 0,25 & 3 \\
\hline $227 / 05$ & Klebsiella pneumoniae & Ambulatório & Urina & 32 & 1,5 & 128 & 8 & $>256$ & 128 & 6 & 6 & 0,047 & 0,125 \\
\hline $243 / 05$ & Klebsiella pneumoniae & Berçário & Secreção Ocular & 6 & 0,25 & $>256$ & 48 & $>256$ & 3 & 8 & 24 & 0,023 & 0,032 \\
\hline $248 / 05$ & Klebsiella pneumoniae & Berçário & Fezes & 8 & 2 & 16 & $>256$ & 256 & 32 & 32 & $>256$ & 0,19 & 1 \\
\hline $253 / 05$ & Klebsiella pneumoniae & UTI & Urina & 32 & 1,5 & 24 & $>256$ & 96 & 32 & 12 & $>256$ & 0,094 & 1,5 \\
\hline $259 / 05$ & Klebsiella pneumoniae & UTI & Escara & 32 & 1,5 & 6 & 128 & $>256$ & 48 & 6 & $>256$ & 0,047 & 0,5 \\
\hline $263 / 05$ & Klebsiella pneumoniae & Clínica Cirúrgica & Urina & 2 & 0,19 & $>256$ & 6 & $>256$ & 1,5 & 6 & 3 & 1,5 & 0,16 \\
\hline $264 / 05$ & Klebsiella pneumoniae & UTI & Prega Axilar & 12 & 0,75 & 64 & $>256$ & $>256$ & 256 & 12 & 256 & 0,64 & 5 \\
\hline $265 / 05$ & Escherichia coli & Clínica Cirúrgica & Fragmento Ósseo & 16 & 3 & 6 & $>256$ & 96 & 48 & 12 & $>256$ & 0,64 & 0,25 \\
\hline $267 / 05$ & Escherichia coli & Clínica Médica & Prega Inguinal & 3 & 0,25 & 48 & 8 & 48 & 0,38 & 8 & 3 & 0,016 & 0,008 \\
\hline $269 / 05$ & Klebsiella pneumoniae & UTI & Urina & 3 & 0,25 & 8 & 128 & 24 & 16 & 8 & 4 & 0,064 & 0,125 \\
\hline $274 / 05$ & Klebsiella pneumoniae & Berçário & Swab Retal & 4 & 0,38 & 256 & 16 & 96 & 4 & 6 & 64 & 0,023 & 0,023 \\
\hline $275 / 05$ & Klebsiella pneumoniae & Berçário & Swab Retal & 3 & 0,38 & $>256$ & 64 & 256 & 6 & 8 & $>256$ & 0,023 & 0,125 \\
\hline $276 / 05$ & Klebsiella pneumoniae & UTI Pediátrica & Secreção Anal & 12 & 0,75 & 4 & $>256$ & 48 & 128 & 16 & $>256$ & 0,094 & 0,25 \\
\hline $286 / 05$ & Klebsiella pneumoniae & Berçário & Swab Retal & 8 & 1 & 32 & 12 & 12 & 3 & 3 & 6 & 0,047 & 0,064 \\
\hline $295 / 05$ & Klebsiella pneumoniae & Berçário & Swab Retal & 3 & 0,19 & $>256$ & 96 & $>256$ & 6 & 16 & 128 & 0,032 & 0,047 \\
\hline $305 / 05$ & Klebsiella pneumoniae & Clínica Pediátrica & Secreção Traqueal & 4 & 0,19 & 256 & 8 & 192 & 2 & 6 & 6 & 0,023 & 0,032 \\
\hline $308 / 05$ & Morganella morganii & Ambulatório & Urina & $>256$ & 16 & 64 & 96 & 16 & 6 & $>256$ & 24 & 0,25 & 0,094 \\
\hline $316 / 05$ & Klebsiella pneumoniae & Clínica Médica & Secreção Purulenta & 8 & 1 & 128 & $>256$ & $>256$ & 64 & 16 & $>256$ & 0,047 & 0,25 \\
\hline $332 / 05$ & Morganella morganii & PS & Urina & $>256$ & 16 & 3 & $>256$ & 24 & 192 & $>256$ & 2 & 0,19 & 0,125 \\
\hline \multicolumn{14}{|c|}{ Cepas Ambientais (n=7) - Junho a Dezembro de 2009} \\
\hline ID FSP & Espécie & Local & Amostra & \multicolumn{10}{|c|}{ CIM $(\mu \mathrm{g} / \mathrm{mL})$} \\
\hline & & & & FOX & CTT & CAZ & CTX & ATM & FEP & AMC & PIP & MEM & ERT \\
\hline $1271 / 09$ & Klebsiella pneumoniae & ETE 1 (Junho/09) & Esgoto Tratado & 3 & 0,25 & 64 & $>256$ & 48 & 48 & 4 & 4 & 0,064 & 0,094 \\
\hline $1312 / 09$ & Escherichia coli & ETE 1 (Agosto/09) & Esgoto Bruto & 4 & 0,25 & 2 & 12 & 3 & 8 & 6 & 4 & 0,047 & 0,016 \\
\hline $1314 / 09$ & Escherichia coli & ETE 1 (Agosto/09) & Esgoto Bruto & 6 & 0,50 & 128 & $>256$ & 256 & 48 & 8 & 32 & 0,023 & 0,023 \\
\hline $1333 / 09$ & Escherichia coli & ETE 2 (Agosto/09) & Esgoto Tratado & 4 & 0,25 & 1 & 12 & 3 & 96 & 6 & 3 & 0,047 & 0,016 \\
\hline $1356 / 09$ & Klebsiella pneumoniae & ETE 3 (Setembro/09) & Esgoto Bruto & 4 & 0,19 & 8 & 128 & 12 & 96 & 8 & 16 & 0,094 & 0,064 \\
\hline $1373 / 09$ & Escherichia coli & ETE 4 (Outubro/09) & Lodo de esgoto & 4 & 0,38 & 1 & 12 & 3 & 96 & 8 & 3 & 0,047 & 0,016 \\
\hline $1471 / 09$ & Enterobacter cloacae & ETE 5 (Dezembro/09) & Lodo de esgoto & $>256$ & 96 & 3 & 48 & 16 & $>256$ & 192 & 6 & 0,094 & 0,75 \\
\hline
\end{tabular}

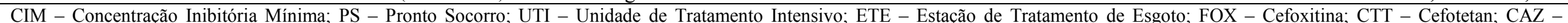

Ceftazidima; CTX - Cefotaxima; ATM - Aztreonam; FEP - Cefepime; AMC - Amoxicilina+Clavulanato; PIP - Piperacilina+Tazobactam; MEM - Meropenem; ERT - Ertapenem. 


\subsection{Extração de DNA total}

A extração do DNA total foi realizada segundo CHAPMAN et al. (2001).

As cepas selecionadas foram reisoladas em Ágar MacConkey e inoculadas em $10 \mathrm{~mL}$ de caldo Luria $0,5 \%$ de $\mathrm{NaCl}$ e incubadas a $35^{\circ} \mathrm{C}$ por $18-24 \mathrm{~h}$. Após centrifugação por 10 minutos a temperatura ambiente, as células do sedimento foram ressuspensas em $1 \mathrm{~mL}$ de água $\mathrm{mQ}^{\circledR}$ estéril e centrifugadas novamente por $3 \mathrm{~min}$.

$\mathrm{O}$ sedimento foi então ressuspenso em $200 \mu \mathrm{L}$ de água $\mathrm{mQ}^{\circledR}$ estéril, e a suspensão foi submetida ao banho de água a $95^{\circ} \mathrm{C}$, por 10 minutos, e em seguida colocada em freezer a $-20^{\circ} \mathrm{C}$, por 30 minutos. Após o descongelamento, foi realizada uma nova centrifugação por $10 \mathrm{~min}$ e o sobrenadante contendo o material genético transferido para um novo microtubo. Os tubos contendo o DNA foram armazenados em freezer a $-20^{\circ} \mathrm{C}$.

\subsection{Desenho dos Iniciadores}

Após alinhamento, por meio do programa Bioedit Sequence Alignment Editor, das sequências disponíveis para genes $b l a_{\mathrm{TEM}}, b l a_{\mathrm{SHV}}$ e $b l a_{\mathrm{CTX}-\mathrm{M}}$ no banco de dados GenBank e de acordo com o site www.lahey.org/studies, organizado por BUSH \& JACOBY (c2003), as regiões codificadoras e dos promotores dos genes foram utilizadas para o desenho de novos iniciadores, para possibilitar a detecção de qualquer gene desses três grandes grupos de enzimas. Os iniciadores foram desenvolvidos no programa Primer-BLAST, o qual utiliza o software $\underline{\text { Primer } 3}$, cuja função é apresentar o número de bases, o valor de TM (ponto de fusão) e a porcentagem de G/C (guanina/citosina) do iniciador desenhado, e o programa 
BLAST para testar os novos iniciadores tanto contra a sequência de base fornecida pelo usuário como as sequências da base de dados GenBank.

Os novos iniciadores e respectivos genes-alvo estão listados no Quadro 4.

\subsection{Pesquisa de Genes Codificadores de ESBL pela PCR}

Foram pesquisados os grupos de genes codificadores das famílias de ESBL TEM, SHV e CTX-M.

Foram utilizadas cepas-controle da coleção de cultura do Laboratório de Prática de Saúde Pública da FSP-USP, validados por sequenciamento, além do

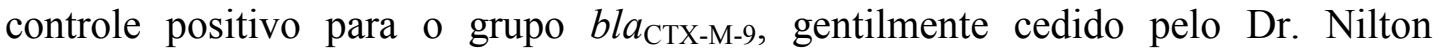
Lincopan, do Laboratório de Resistência Bacteriana e Alternativas Terapêuticas do Instituto de Ciências Biomédicas da USP (ICB-USP) (Quadro 3).

Quadro 3. Relação das cepas-controle utilizadas nas reações de PCR do estudo.

\begin{tabular}{|c|c|c|}
\hline ID & Espécie & Grupo de Genes \\
\hline \multirow{2}{*}{ FSP202/05 } & \multirow{2}{*}{ K. pneumoniae } & bla $_{\mathrm{TEM}}$ \\
\cline { 3 - 3 } & K. pneumoniae & bla $_{\mathrm{SHV}}$ \\
\hline FSP1271/09 & K. pneumoniae & bla $a_{\mathrm{CTX}-\mathrm{M}-2}$ \\
\hline FSP202/05 & E. coli & bla $a_{\mathrm{CTX}-\mathrm{M}-8}$ \\
\hline FSP1312/09 & E. coli & bla \\
\hline ICTX-M-9 \\
\hline não houve cepa-controle & ------ & bla \\
CTX-M-25/outros \\
\hline
\end{tabular}

Cada microtubo de reação continha um volume total de $25 \mu \mathrm{L}$, com a seguinte composição: DNA total $5 \mu \mathrm{L}$, tampão $1 \mathrm{X}, \mathrm{MgCl}_{2} 1,5 \mathrm{mM}$, dntp $200 \mu \mathrm{M}$, iniciadores 0,5 $\mu \mathrm{M}$ cada, e Taq DNA polimerase 1,25U (GoTaq ${ }^{\circledR}$ DNA Polymerase, Promega, WI, EUA). 
A reação ocorreu com uma denaturação inicial a $94^{\circ} \mathrm{C}$ por 2 min., seguida de 30 ciclos consistindo de: denaturação a $94^{\circ} \mathrm{C}$ por 45 s, anelamento $55^{\circ} \mathrm{C}$ por 1 min., e extensão a $72^{\circ} \mathrm{C}$ por 1 minuto. Após a finalização dos ciclos, houve uma extensão final a $72^{\circ} \mathrm{C}$ por 10 minutos.

Quadro 4. Seqüências dos iniciadores desenvolvidos neste estudo para a pesquisa dos genes bla $a_{\mathrm{ESBL}}$.

\begin{tabular}{|c|c|c|c|}
\hline Iniciador & Sequência 5'-3' & Alvo & $\begin{array}{l}\text { Produto } \\
\text { (pb) }\end{array}$ \\
\hline \multirow{3}{*}{$\begin{array}{c}\text { TEM P F } \\
\text { TEM CR F } \\
\text { TEM R }\end{array}$} & TAAAATTCTTGAAGACGAA & \multirow{3}{*}{ Grupo $b l a_{\mathrm{TEM}}$} & \multirow{3}{*}{$\begin{array}{c}1066 \\
839\end{array}$} \\
\hline & CGWGTCGCCCTTATTCCCT & & \\
\hline & CCAAWGCTTAATCAGTGAG & & \\
\hline \multirow{3}{*}{$\begin{array}{c}\text { SHV F } \\
\text { SHV R } \\
\text { SHV-5r R }\end{array}$} & TTATCTCCCTGTTAGCCRCC & \multirow{3}{*}{ Grupo $b l a_{\mathrm{SHV}}$} & \multirow{3}{*}{$\begin{array}{l}838 \\
870\end{array}$} \\
\hline & TTAGCGTTGCCAGTGYTCGA & & \\
\hline & GCTAGCAAGCGGGGTGCG & & \\
\hline CTX-M-1 F & AAATCACTGCGYCAGTTCA & \multirow{2}{*}{ Grupo $b a_{\mathrm{CTX- \textrm {M } - 1}}$} & \multirow{2}{*}{854} \\
\hline CTX-M-1 R & GGTGACGATTTTAGCCGCCG & & \\
\hline \multirow{2}{*}{$\begin{array}{l}\text { CTX-M-2 F } \\
\text { CTX-M-2 R }\end{array}$} & GACTCAGAGCATTCGCCGC & \multirow{2}{*}{ Grupo $b l a_{\text {СтХ-M-2 }}$} & \multirow{2}{*}{870} \\
\hline & TCAGAAACCGYGGGTTACGA & & \\
\hline \multirow{2}{*}{$\begin{array}{l}\text { CTX-M-8 F } \\
\text { CTX-M-8 R }\end{array}$} & GATGAGACATCGCGTTAAG & \multirow{2}{*}{ Grupo $b l a_{\text {СтХ-M-8 }}$} & \multirow{2}{*}{861} \\
\hline & GGTGACGATTTTCGCGGCA & & \\
\hline \multirow{2}{*}{$\begin{array}{l}\text { CTX-M-9 F } \\
\text { CTX-M-9 R }\end{array}$} & TGACAAAGAGARTGCAACGG & \multirow{2}{*}{ Grupo $b l a_{\text {СтХ-м-9 }}$} & \multirow{2}{*}{857} \\
\hline & CGATGATTCTCGCCGCTGAA & & \\
\hline CTX-M-25 F & ATGAGAAAAAGCGTAAGGCGGG & Grupo bla $a_{\mathrm{CTX}-\mathrm{M}-}$ & 865 \\
\hline CTX-M-25 R & CCGTCGGTGACWATTCTG & $\begin{array}{l}\text { 25, e demais } \\
\text { genes bla }\end{array}$ & 803 \\
\hline
\end{tabular}

Para a visualização dos produtos amplificados, juntamente com o marcador de peso molecular (100bp Plus MassRuler ${ }^{\mathrm{TM}}$ DNA Ladder, Fermentas), foi realizada uma eletroforese a $6 \mathrm{~V} / \mathrm{cm}$ em gel de agarose a $1,5 \%$, corado com brometo de etídio e visualizado em luz ultravioleta (Epi Chemi II Darkroom, UVP Bioimaging Systems). 
Os fragmentos positivos foram purificados por meio de kit comercial (illustra $^{\mathrm{TM}}$ GFX ${ }^{\mathrm{TM}}$ DNA and Gel Band Purification Kit, GE Healthcare, UK) de acordo com as instruções do fabricante, sequenciados e analisados por meio do software Bioedit Sequence Alignment Editor.

\subsection{Determinação do Ambiente Genético dos Genes bla $a_{\mathrm{ESBL}}$}

Após a identificação dos genes $b l a_{\mathrm{ESBL}}$, foi pesquisado o ambiente genético dos mesmos, pelo mapeamento de alguns elementos móveis ou mobilizáveis, por meio de PCR e sequenciamento. O objetivo desta etapa do estudo foi determinar se os genes bla $a_{\mathrm{ESBL}}$ estariam ou não associados a estes elementos, uma vez que o mapeamento completo do conteúdo genético envolvido no evento de mobilização só seria possível em um estudo que envolvesse um menor número de cepas.

Inicialmente, foi realizada a triagem de alguns elementos genéticos que, segundo a literatura consultada, poderiam estar relacionados aos genes $b l a_{\mathrm{ESBL}}$. O Quadro 5 apresenta os elementos pesquisados, com seus respectivos iniciadores e genes aos quais estariam relacionados. A pesquisa de integrases 2 e 3 foi realizada para todas as cepas. 
Quadro 5. Seqüências de iniciadores utilizados na triagem dos elementos genéticos móveis relacionados aos genes $b l a_{\mathrm{ESBL}}$.

\begin{tabular}{|c|c|c|c|c|c|}
\hline Iniciador & Sequência 5'-3' & Alvo & $\begin{array}{c}\text { Genes } \\
\text { Relacionados }\end{array}$ & $\begin{array}{c}\text { Produto } \\
\text { (pb) }\end{array}$ & Referência \\
\hline $\begin{array}{l}\text { IntI } 1 \text { F } \\
\text { IntI } 1 \text { R }\end{array}$ & $\begin{array}{l}\text { ACATGTGATGGCGACGCACGA } \\
\text { ATTTCTGTCCTGGCTGGCGA }\end{array}$ & intI 1 & $b l a_{\text {СтХ-м }}$ & 569 & \multirow{2}{*}{$\begin{array}{l}\text { PAN et al. } \\
\quad 2006\end{array}$} \\
\hline $\begin{array}{l}\text { IntI } 2 \text { F } \\
\text { IntI } 2 \text { R }\end{array}$ & $\begin{array}{l}\text { GTAGCAAACGAGTGACGAAATG } \\
\text { CACGGATATGCGACAAAAAGGT }\end{array}$ & intI 2 & & 789 & \\
\hline $\begin{array}{l}\text { IntI } 3 \text { F } \\
\text { IntI } 3 \text { R }\end{array}$ & $\begin{array}{l}\text { CATTTGTGTTGTGGACGGC } \\
\text { GACAGATACGTGTTTGGCAA }\end{array}$ & intI 3 & & 717 & $\begin{array}{c}\text { XU et al. } \\
2009\end{array}$ \\
\hline $\begin{array}{l}\text { ISEcp1 F } \\
\text { ISEcp1 R }\end{array}$ & $\begin{array}{l}\text { GCAGGTCTTTTTCTGCTCC } \\
\text { TTTCCGCAGCACCGTTTGC }\end{array}$ & $\begin{array}{l}\text { tnpA de } \\
\text { ISEcpl }\end{array}$ & bla $_{\mathrm{CTX- \textrm {M }}}$ & 535 & \multirow{2}{*}{$\begin{array}{l}\text { PARK et al. } \\
\quad 2009\end{array}$} \\
\hline $\begin{array}{l}\text { ISCR1 F } \\
\text { ISCR1 R }\end{array}$ & $\begin{array}{l}\text { AAGGAACGCCACGGCGAGTCAA } \\
\text { TGCAAAGACGCCGTGGAAGC }\end{array}$ & $\begin{array}{l}\operatorname{tnp} A \text { de } \\
\text { ISCRI }\end{array}$ & $b l a_{\mathrm{CTX}-\mathrm{M}}$ & 1200 & \\
\hline $\begin{array}{l}\text { IS26 F } \\
\text { IS26 R }\end{array}$ & $\begin{array}{l}\text { CAGCGTGACATCATTCTGTG } \\
\text { TCTGCTTACCAGGCGCATTT }\end{array}$ & $\begin{array}{l}\text { tnp } A \text { de } \\
\text { IS26 }\end{array}$ & $\begin{array}{l}b l a_{\mathrm{CTX}-\mathrm{M}} \\
b l a_{\mathrm{SHV}}\end{array}$ & 662 & Este estudo \\
\hline $\begin{array}{l}\text { Tn1/2/3 F } \\
\text { TEM R }\end{array}$ & $\begin{array}{l}\text { ATGCGAMTTTTTGGTTAYGC } \\
\text { CCAAWGCTTAATCAGTGAG }\end{array}$ & $\begin{array}{c}\operatorname{tnpR} R \text { de } \\
\text { Tn } 1,2 \text { e } 3\end{array}$ & $b l a_{\mathrm{TEM}}$ & Variável & $\begin{array}{l}\text { PARTRIDGE } \\
\text { \& HALL } \\
2005\end{array}$ \\
\hline
\end{tabular}

\subsubsection{Genes bla TEM}

O ambiente genético dos genes $b l a_{\mathrm{TEM}}$ que codificam enzimas ESBL foi determinado por meio do sequenciamento do produto de PCR obtido na reação de triagem dos transposons $\operatorname{Tn} 1, \operatorname{Tn} 2$ e $\operatorname{Tn} 3$ descrita acima, a qual já foi realizada com o iniciador reverso para os genes bla $a_{\mathrm{TEM}}$ (Figura 6).

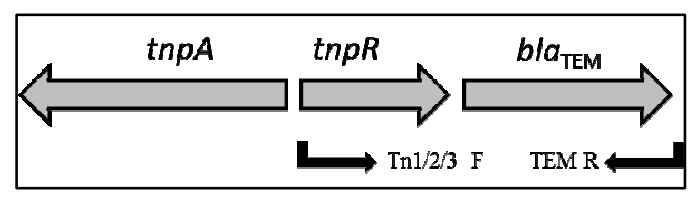

Figura 6. Esquema da estrutura dos transposons $\operatorname{Tn} 1,2$ e 3 quando associados a genes $b l a_{\mathrm{TEM}}$. Setas pretas indicam a posição dos iniciadores utilizados no mapeamento. 


\subsubsection{Genes bla ${ }_{S H V}$}

De acordo com as estruturas geralmente descritas na literatura para a associação da IS26 com genes $b l a_{\mathrm{SHV}}$, foram realizadas amplificações utilizando apenas iniciadores reversos (Figura 7).

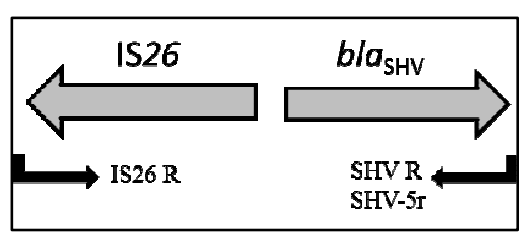

Figura 7. Esquema da associação mais comum entre IS26 e genes bla $a_{\mathrm{SHV}}$. Setas pretas indicam a posição dos iniciadores utilizados no mapeamento.

\subsubsection{Genes bla ${ }_{C T X-M}$}

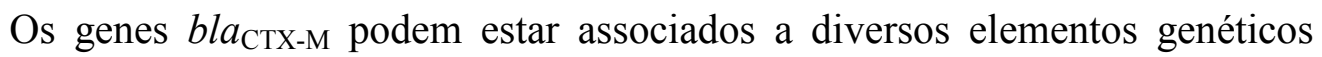
mobilizáveis, como integrons de classe 1 simples ou complexos, ou sequências de inserção, especialmente ISCR1, ISEcp 1 e IS26.

Uma vez que genes $b l a_{\text {CTX-M-2 }}$ estão frequentemente ligados à ISCRI e inseridos em integrons de classe 1 complexos, novos iniciadores foram desenhados e a amplificação representada na Figura 8 foi realizada:

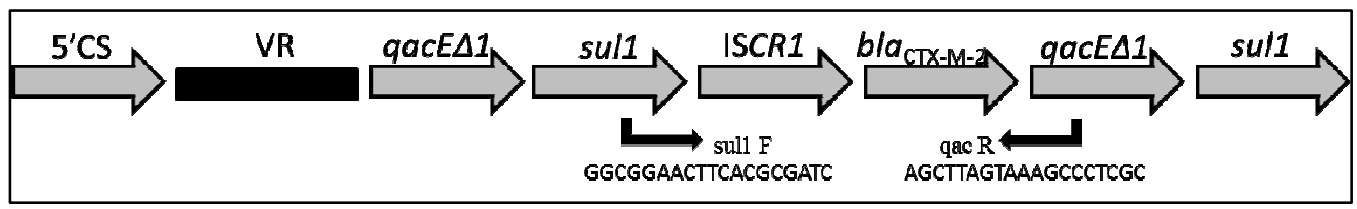

Figura 8. Esquema do integron de classe 1 complexo. Setas pretas indicam a posição dos iniciadores utilizados no mapeamento. 
Para os genes dos demais grupos de CTX-M, mais comumente associados à ISEcp 1 e/ou IS26, as reações esquematizadas na Figura 9 foram realizadas:

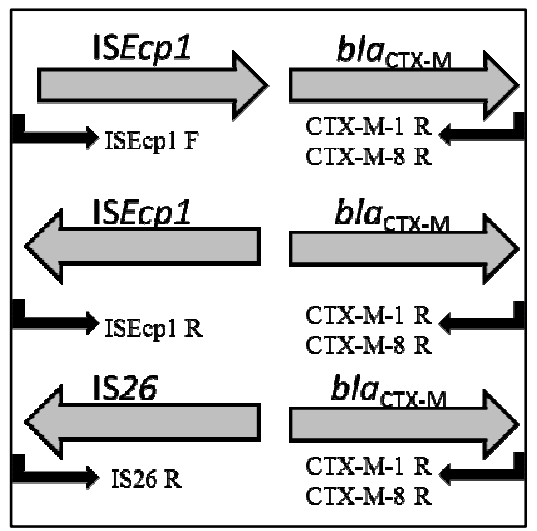

Figura 9. Possíveis associações das sequências de inserção ISEcpl e IS 26 com genes

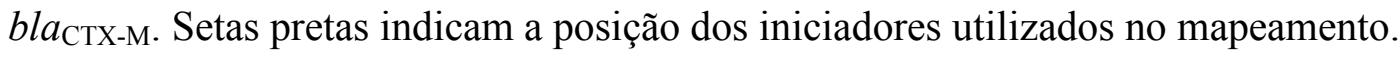

Os produtos amplificados foram purificados por meio de kit comercial (illustra $^{\mathrm{TM}}$ GFX ${ }^{\mathrm{TM}}$ DNA and Gel Band Purification Kit, GE Healthcare, UK), de acordo com as instruções do fabricante, e encaminhados para o seqüenciamento, cujos resultados foram analisados por meio de alinhamento no programa Bioedit Sequence Alignment Editor, comparando sequências de nucleotídeos obtidas nos resultados com aquelas existentes no banco de dados GenBank.

\subsection{Tipagem Plasmidial por PCR-Based Replicon Typing (PBRT)}

Os plasmídios foram classificados de acordo com seus grupos Inc, pela metodologia padronizada por CARATTOLI et al. (2005) (Quadro 6). Não foram utilizados controles positivos, porém os produtos de PCR positivos foram sequenciados para validação das reações. 
O DNA plasmidial utilizado nas reações de PCR foi extraído por kit comercial (Wizard Plus SV Minipreps, Promega, USA), de acordo com as instruções do fabricante. As sequências e os alvos para os 18 pares de iniciadores utilizados nas reações estão no Quadro 6.

O PBRT consiste em cinco reações de PCR multiplex, para reconhecimento de 3 tipos de replicons cada, e três reações simples para IncF, IncK e IncB/O. As condições de reação para todas as amplificações, exceto a de IncF, são: denaturação inicial a $94^{\circ} \mathrm{C}$ por 5 min., seguida de 30 ciclos consistindo de: denaturação a $94^{\circ} \mathrm{C}$ por 1 min., anelamento a $60^{\circ} \mathrm{C}$ por $30 \mathrm{~s}$, e extensão a $72^{\circ} \mathrm{C}$ por 1 minuto. Após a finalização dos ciclos, há uma extensão final a $72^{\circ} \mathrm{C}$ por 5 minutos. Para a reação do grupo IncF, a temperatura de anelamento passa a ser $52^{\circ} \mathrm{C}$.

Para a visualização dos produtos amplificados, juntamente com o marcador de peso molecular (100bp Plus MassRuler ${ }^{\mathrm{TM}}$ DNA Ladder, Fermentas), foi realizada uma eletroforese a $6 \mathrm{~V} / \mathrm{cm}$ em gel de agarose a $1,5 \%$, corado com brometo de etídio e visualizado em luz ultravioleta (Epi Chemi II Darkroom, UVP Bioimaging Systems). 
Quadro 6. Sequências de iniciadores para a tipagem plasmidial em grupos Inc (CARATTOLI et al. 2005).

\begin{tabular}{|c|c|c|c|}
\hline Iniciador & Sequência 5'-3' & Alvo & $\begin{array}{c}\text { Produto } \\
\text { (pb) }\end{array}$ \\
\hline $\begin{array}{l}\text { H11 F } \\
\text { H11 R }\end{array}$ & $\begin{array}{l}\text { GGAGCGATGGATTACTTCAGTAC } \\
\text { TGCCGTTTCACCTCGTGAGTA }\end{array}$ & parA-parB & 471 \\
\hline $\begin{array}{l}\text { H12 F } \\
\text { H12 R }\end{array}$ & $\begin{array}{l}\text { TTTCTCCTGAGTCACCTGTTAACAC } \\
\text { GGCTCACTACCGTTGTCATCCT }\end{array}$ & iterons & 644 \\
\hline $\begin{array}{l}\text { I1 F } \\
\text { I1 R }\end{array}$ & $\begin{array}{l}\text { CGAAAGCCGGACGGCAGAA } \\
\text { TCGTCGTTCCGCCAAGTTCGT }\end{array}$ & RNAI & 139 \\
\hline $\begin{array}{l}X \mathbf{F} \\
\mathbf{X ~ R}\end{array}$ & $\begin{array}{l}\text { AACCTTAGAGGCTATTTAAGTTGCTGAT } \\
\text { TGAGAGTCAATTTTTATCTCATGTTTTAGC }\end{array}$ & ori $\gamma$ & 376 \\
\hline $\begin{array}{l}\mathbf{L} / \mathbf{M ~ F} \\
\mathbf{L} / \mathbf{M ~ R}\end{array}$ & $\begin{array}{l}\text { GGATGAAAACTATCAGCATCTGAAG } \\
\text { CTGCAGGGGCGATTCTTTAGG }\end{array}$ & $\operatorname{repA}, \mathrm{B}, \mathrm{C}$ & 785 \\
\hline $\begin{array}{l}\mathbf{N} \mathbf{F} \\
\mathbf{N} \mathbf{R}\end{array}$ & $\begin{array}{l}\text { GTCTAACGAGCTTACCGAAG } \\
\text { GTTTCAACTCTGCCAAGTTC }\end{array}$ & repA & 559 \\
\hline $\begin{array}{l}\text { FIA F } \\
\text { FIA R }\end{array}$ & $\begin{array}{l}\text { CCATGCTGGTTCTAGAGAAGGTG } \\
\text { GTATATCCTTACTGGCTTCCGCAG }\end{array}$ & iterons & 462 \\
\hline $\begin{array}{l}\text { FIB F } \\
\text { FIB R }\end{array}$ & $\begin{array}{l}\text { GGAGTTCTGACACACGATTTTCTG } \\
\text { CTCCCGTCGCTTCAGGGCATT }\end{array}$ & repA & 702 \\
\hline $\begin{array}{l}\mathbf{W} \mathbf{F} \\
\mathbf{W} \mathbf{R}\end{array}$ & $\begin{array}{l}\text { CCTAAGAACAACAAAGCCCCCG } \\
\text { GGTGCGCGGCATAGAACCGT }\end{array}$ & repA & 242 \\
\hline $\begin{array}{l}\text { Y F } \\
\mathbf{Y} \mathbf{R}\end{array}$ & $\begin{array}{l}\text { AATTCAAACAACACTGTGCAGCCTG } \\
\text { GCGAGAATGGACGATTACAAAACTTT }\end{array}$ & repA & 765 \\
\hline $\begin{array}{l}\mathbf{P} \mathbf{F} \\
\mathbf{P} \mathbf{R}\end{array}$ & $\begin{array}{l}\text { CTATGGCCCTGCAAACGCGCCAGAAA } \\
\text { TCACGCGCCAGGGCGCAGCC }\end{array}$ & iterons & 534 \\
\hline $\begin{array}{l}\text { FIC F } \\
\text { FIC R }\end{array}$ & $\begin{array}{l}\text { GTGAACTGGCAGATGAGGAAGG } \\
\text { TTCTCCTCGTCGCCAAACTAGAT }\end{array}$ & repA2 & 262 \\
\hline $\begin{array}{l}\mathbf{A} / \mathbf{C} \mathbf{F} \\
\mathbf{A} / \mathbf{C} \mathbf{R}\end{array}$ & $\begin{array}{l}\text { GAGAACCAAAGACAAAGACCTGGA } \\
\text { ACGACAAACCTGAATTGCCTCCTT }\end{array}$ & repA & 465 \\
\hline $\begin{array}{l}\mathbf{T} \mathbf{F} \\
\mathbf{T} \mathbf{R}\end{array}$ & $\begin{array}{l}\text { TTGGCCTGTTTGTGCCTAAACCAT } \\
\text { CGTTGATTCACCTTAGCTTTGGAC }\end{array}$ & repA & 750 \\
\hline $\begin{array}{l}\text { FII }_{\mathrm{s}} \mathbf{F} \\
\text { FII }_{\mathrm{s}} \mathbf{R}\end{array}$ & $\begin{array}{l}\text { CTGTCGTAAGCTGATGGC } \\
\text { CTCTGCCACAAACTTCAGC }\end{array}$ & repA & 270 \\
\hline $\begin{array}{l}\mathbf{F}_{\text {repB }} \mathbf{F} \\
\mathbf{F}_{\text {repB }} \mathbf{R}\end{array}$ & $\begin{array}{l}\text { TGATCGTTTAAGGAATTTTG } \\
\text { GAAGATCAGTCACACCATCC }\end{array}$ & $\begin{array}{l}\text { RNAI/rep } \\
\text { A }\end{array}$ & 270 \\
\hline $\begin{array}{l}\text { K/B F } \\
\text { K R }\end{array}$ & $\begin{array}{l}\text { GCGGTCCGGAAAGCCAGAAAAC } \\
\text { TCTTTCACGAGCCCGCCAAA }\end{array}$ & RNAI & 160 \\
\hline $\begin{array}{l}\text { K/B F } \\
\text { B/O R }\end{array}$ & $\begin{array}{l}\text { GCGGTCCGGAAAGCCAGAAAAC } \\
\text { TCTGCGTTCCGCCAAGTTCGA }\end{array}$ & RNAI & 159 \\
\hline
\end{tabular}




\subsection{Detecção e Determinação do Tamanho dos Plasmídios}

\subsubsection{Preparo dos Plugs}

A extração do DNA em moldes para eletroforese em campo pulsado foi realizada de acordo com DROPA (2006).

Cada cepa foi cultivada em $30 \mathrm{~mL}$ de caldo Luria $0,5 \% \mathrm{NaCl}$, por $18-24 \mathrm{~h}$ a $37^{\circ} \mathrm{C}$. As células foram ressuspensas em $1 \mathrm{~mL}$ de solução tampão TE I (Tris- $\mathrm{HCl}$ 10mM, pH 7,5; EDTA 1mM, pH 8,0) e transferidas para microtubos tipo eppendorf, os quais foram centrifugados a $12.000 \mathrm{RPM}$ por 5 minutos a $24^{\circ} \mathrm{C}$. A seguir, foram adicionados às células $400 \mu \mathrm{L}$ de TE I, e desta suspensão, $80 \mu \mathrm{L}$ foram adicionados a $320 \mu \mathrm{L}$ de agarose de baixo ponto de fusão (low melting) a $1 \%$, a $55-60^{\circ} \mathrm{C}$. Em seguida, os moldes para confecção dos plugs foram preenchidos e incubados por 15 minutos a $4^{\circ} \mathrm{C}$, para solidificação.

Os plugs foram então retirados dos moldes e colocados em $5 \mathrm{~mL}$ de uma solução de lise (EDTA 50mM, pH8,0; Tris-HCl 50mM, pH 7,5; SDS 20\%, Sarkosyl $1 \%$, proteinase $\mathrm{K} 20 \mathrm{mg} / \mathrm{mL}$ ), em tubos tipo Falcow ${ }^{\circledR}$, e incubados a $55^{\circ} \mathrm{C}$ por $2 \mathrm{~h}$.

Após a incubação, foram realizadas 2 lavagens dos plugs em 10mL de água $\mathrm{mQ}^{\circledR}$ e 4 lavagens em 10mL de TE I (Tris-HCl 10mM, pH 7,5; EDTA 1mM, pH8,0), com intervalos de $15 \mathrm{~min}$, a $55^{\circ} \mathrm{C}$.

Os plugs foram então transferidos para um microtubo tipo Eppendorf ${ }^{\circledR} \mathrm{e}$ estocados em $1 \mathrm{~mL}$ de TE I a $4^{\circ} \mathrm{C}$, até o momento do uso. 


\subsubsection{S1 - PFGE}

Para a conversão de plasmídios superenovelados (supercoiled) em plasmídios lineares, foi realizada a digestão dos plugs com a enzima S1 nuclease (Promega, WI, EUA) $10 \mathrm{U}$ por plug, em $350 \mu \mathrm{L}$ de tampão da enzima fornecido pelo fabricante. A digestão ocorreu a $37^{\circ} \mathrm{C}$ por $45 \mathrm{~min}$, e a reação foi interrompida transferindo-se o plug para um novo microtubo com tampão TE I (BARTÓN et al. 1995; MSHANA et al. 2009).

Após a digestão com S1, os plugs contendo plasmídios lineares foram submetidos à eletroforese em campo pulsado (Chef Mapper (Bio-Rad Laboratories, Hercules, CA). Em um gel de agarose para Pulsed Field a 1\% em solução tampão TBE 0,5X (Tris-borato 45mM, EDTA dissódico 1mM, pH 8,0), foram colocados os plugs das amostras e de marcadores de peso molecular (Lambda Ladder PFG Marker e MidRange PFG Marker I, New England Biolabs, USA). As condições utilizadas na eletroforese foram: voltagem de $6 \mathrm{~V} / \mathrm{cm}$, a $14^{\circ} \mathrm{C}$, por $20 \mathrm{~h}$, com intervalo de pulsos de $1 \mathrm{~s}$ a $40 \mathrm{~s}$.

O gel de PFGE foi corado em brometo de etídio $1 \mu \mathrm{g} / \mathrm{mL}$, durante $1 \mathrm{~h}$, e visualizado em luz ultravioleta (Epi Chemi II Darkroom, UVP Bioimaging Systems). O tamanho dos plasmídios foi determinado pela comparação com as bandas dos marcadores de peso molecular. 


\section{RESULTADOS}

\subsection{Detecção de Genes bla $_{\mathrm{ESBL}}$ e seus Ambientes Genéticos}

Do total de 45 isolados clínicos, 36 (80\%) possuíam genes bla $a_{\mathrm{TEM}}, 33$ $(73,3 \%)$ possuíam bla $_{\mathrm{SHV}}$ e $30(66,7 \%)$ possuíam genes do grupo bla $a_{\mathrm{CTX}-\mathrm{M}-2}$. Dentre os isolados ambientais, $3(42,8 \%)$ possuíam bla TEM, $_{2} 2(28,6 \%)$ possuíam bla SHV $_{2} 2$ (28,6\%) possuíam genes do grupo bla $a_{\mathrm{CTX}-\mathrm{M}-1}$ e $5(71,4 \%)$ possuíam genes do grupo $b_{\text {CTX-M-8 }}$ (Tabela 2).

Tabela 2. Número e porcentagem de cepas clínicas e ambientais positivas para a presença de cada grupo de genes bla.

\begin{tabular}{lll}
\hline Grupos de Genes & $\begin{array}{l}\text { Cepas Clínicas } \\
\mathbf{n}(\%)\end{array}$ & $\begin{array}{l}\text { Cepas Ambientais } \\
\mathbf{n}(\%)\end{array}$ \\
\hline bla $_{\text {TEM }}$ & $36(80)$ & $3(42,8)$ \\
bla $_{\text {SHV }}$ & $33(73,3)$ & $2(28,6)$ \\
bla $_{\text {CTX-M-1 }}$ & $0(0)$ & $2(28,6)$ \\
bla $_{\text {CTX-M-2 }}$ & $30(66,7)$ & $0(0)$ \\
bla $_{\text {CTX-M-8 }}$ & $0(0)$ & $5(71,4)$ \\
\hline
\end{tabular}

\subsubsection{TEM}

Entre os genes bla $a_{\mathrm{TEM}}$ amplificados em cepas clínicas (n=36), 33 (91,7\%) eram genes não codificadores de ESBL $b l a_{\mathrm{TEM}-1 \mathrm{~A}}(11)$ e $b l a_{\mathrm{TEM}-1 \mathrm{~B}}(22)$, distribuídos entre todas as espécies. Os demais genes $b l a_{\mathrm{TEM}}$ detectados foram $b l a_{\mathrm{TEM}-15}$, em apenas uma cepa de K. pneumoniae da UTI Adulta (FSP264/05, colonização), e o novo bla $_{\mathrm{TEM}-197}$, muito semelhante ao $b \operatorname{la}_{\mathrm{TEM}-15}$ com a substituição de aminoácido Ala $_{184} \rightarrow$ Val, em 2 isolados de $K$. pneumoniae, uma originária do Berçário (FSP286/05, colonização) e outra da UTI Neonatal (FSP287/05, infecção hospitalar). 
Dentre os isolados das ETEs, apenas os genes não-ESBL bla $a_{\mathrm{TEM}-1 \mathrm{~A}}(\mathrm{n}=2)$ e $\operatorname{bla}_{\text {TEM-1B }}(\mathrm{n}=1)$ foram detectados.

Em nenhum isolado foi detectado mais de um gene $b l a_{\mathrm{TEM}}$.

A triagem dos elementos $\operatorname{Tn} 1, \operatorname{Tn} 2, \operatorname{Tn} 3$, int 2 e int 3 foi realizada apenas para as 3 cepas que continham bla $a_{\mathrm{TEM}}$ codificadores de ESBL. Todas foram negativas para int2 e int3.

A cepa clínica de $K$. pneumoniae produtora de TEM-15 possui também genes codificadores de SHV-110 e CTX-M-2. A análise do sequenciamento do produto de 1,5kb obtido na PCR utilizando os iniciadores Tn1/2/3 F e TEM R revelou que o gene bla $_{\mathrm{TEM}-15}$ está associado ao transposon Tn2* (Figura 10A) (PARTRIDGE \& HALL 2004).

A nova enzima TEM-197 foi detectada em dois isolados clínicos de $K$. pneumoniae, sendo que um deles também possui SHV-5. O produto de $1,5 \mathrm{~kb}$ mencionado anteriormente também foi obtido para estas cepas, revelando que o gene $b l a_{\mathrm{TEM}-197}$ está associado ao transposon Tn3 (Figura 10B).

Os resultados descritos acima para as cepas produtoras de TEM-15 e TEM197 estão resumidos na Tabela 3, e a Tabela 6 apresenta os resultados gerais deste estudo. 


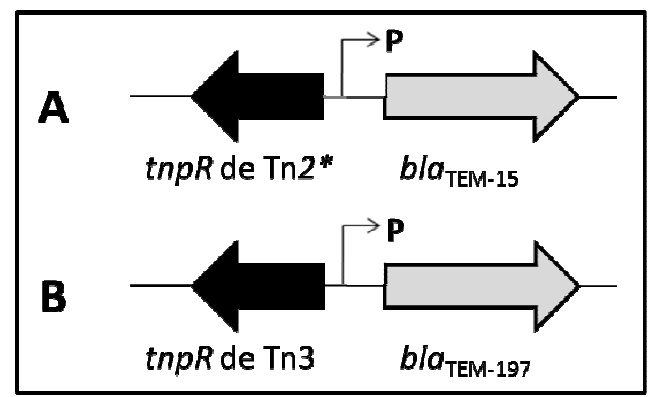

Figura 10. Representação esquemáttica do ambiente genético dos genes $b l a_{\mathrm{TEM}}$. A - Parte da estrutura do transposon Tn2*, associado ao gene bla $a_{\mathrm{TEM}-15}$. B - Parte da estrutura do transposon $T n 3$, associado ao gene $b l a_{\mathrm{TEM}-197}$.

Tabela 3. Características das cepas clínicas de $K$. pneumoniae contendo genes $b l a_{\text {TEM }}$ que codificam enzimas ESBL.

\begin{tabular}{|c|c|c|c|c|}
\hline Cepa & Tipo de Infecção & Setor & ESBL & Ambiente Genético \\
\hline FSP264/05 & $\begin{array}{l}\text { colonização } \\
\text { (prega axilar) }\end{array}$ & UTI Adulta & TEM-15 & $\operatorname{Tn} 2 *$ \\
\hline FSP286/05 & $\begin{array}{l}\text { colonização } \\
\text { (swab retal) }\end{array}$ & Berçário & TEM-197 & $\operatorname{Tn} 3$ \\
\hline FSP287/05 & $\begin{array}{l}\text { infecção hospitalar } \\
\text { (líquido peritonial) }\end{array}$ & UTI Neonatal & TEM-197 & $\operatorname{Tn} 3$ \\
\hline
\end{tabular}

\subsubsection{SHV}

Em relação aos genes bla $_{\mathrm{SHV}}$, dos 33 isolados clínicos positivos, $28(84,8 \%)$ eram $K$. pneumoniae, e os demais eram $E$. coli (4) e $K$. oxytoca (1). Uma cepa de $K$. pneumoniae (FSP286/05) foi negativa para a presença de genes bla $a_{\mathrm{SHV}}$. A análise do seqüenciamento revelou que 6 isolados de $K$. pneumoniae possuíam mais de um gene $b l a_{\mathrm{SHV}}$. Os genes $b l a_{\mathrm{SHV}}$ identificados nas cepas clínicas foram: bla $a_{\mathrm{SHV}-5}(12), b l a_{\mathrm{SHV}}$ 12 (7), $\operatorname{bla}_{\mathrm{SHV}-27}(2), \operatorname{bla}_{\mathrm{SHV}-28}(5), \operatorname{bla}_{\mathrm{SHV}-45}(1), b_{\mathrm{SHV}-55}$ (1) e bla $a_{\mathrm{SHV}-110}$ (2) (Tabela 6). Foram também detectados os genes não codificadores de ESBL bla $a_{\mathrm{SHV}-1}$ (2) e bla $_{\mathrm{SHV}-11}(7)$. 
As cepas contendo genes $b l a_{\mathrm{SHV}}$ estavam distribuídas em todos os setores do hospital, em cepas isoladas de colonizações e infecções hospitalares e comunitárias (Figuras 11 e 12).

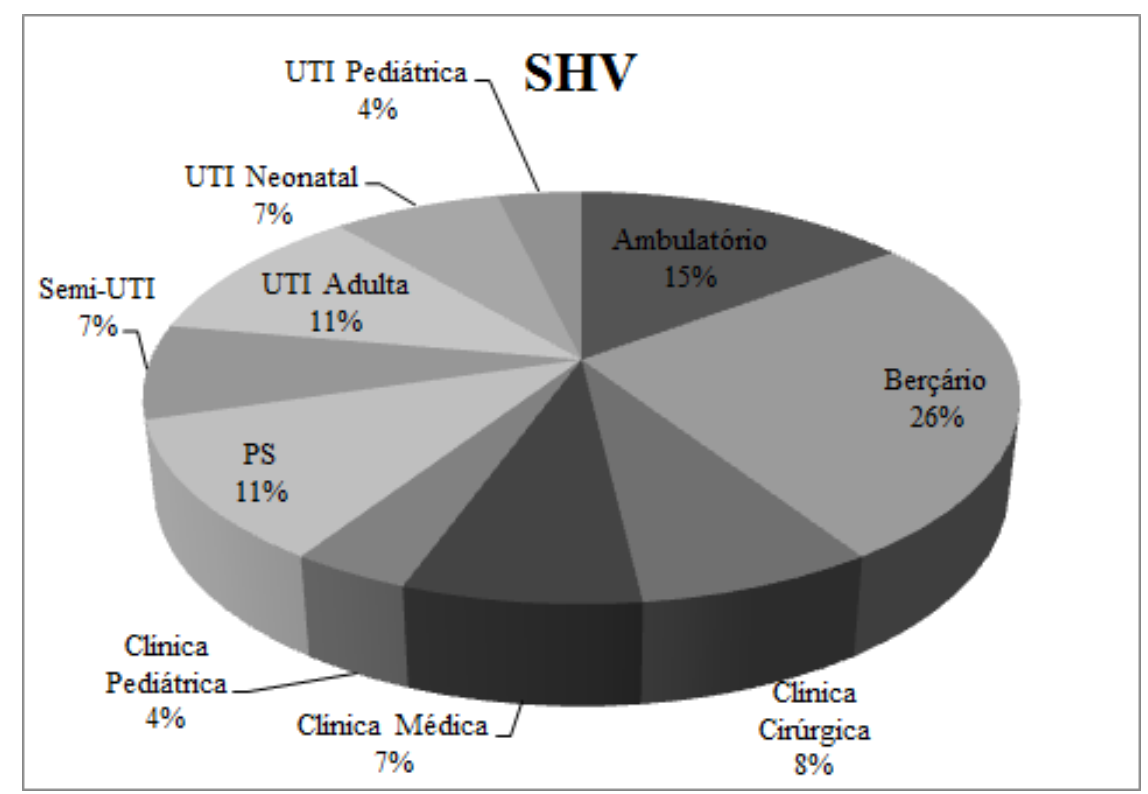

Figura 11. Distribuição em porcentagem das cepas produtoras de ESBL do grupo SHV de acordo com o setor hospitalar onde foram isoladas.

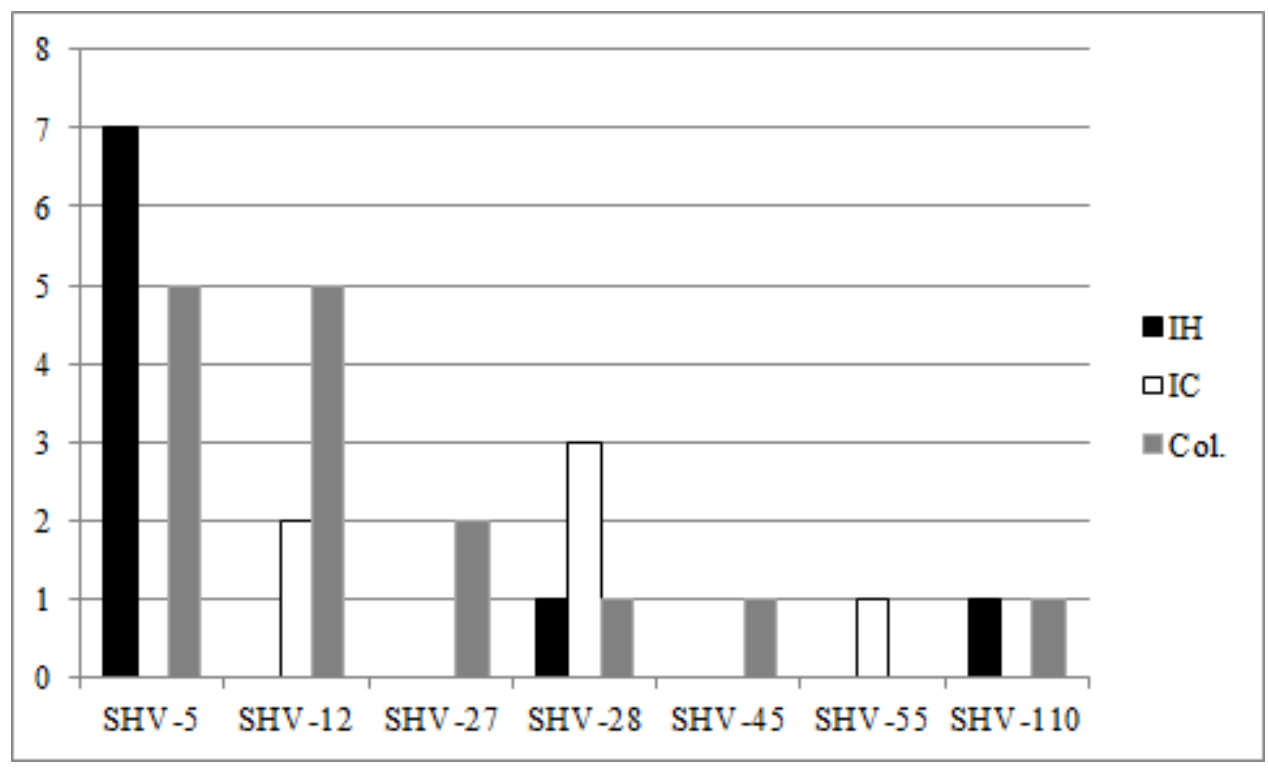

Figura 12. Número de cepas produtoras de ESBL do grupo SHV de acordo com o tipo de infecção. IH - Infecção Hospitalar; IC - Infecção Comunitária; Col. Colonização. 
Com relação às duas cepas ambientais de $K$. pneumoniae positivas para $b l a_{\mathrm{SHV}}$, uma possui o gene bla $_{\mathrm{OKP}-\mathrm{B}-13}$ (FSP1356/09), que codifica uma enzima do grupo OKP - Other K. pneumoniae $\beta$-lactamases, similar às SHV e não codificadora de ESBL (FEVRE et al. 2005), e a outra possui o gene bla $a_{\mathrm{SHV}-28}(\mathrm{FSP} 1271 / 09)$, também detectado nas cepas clínicas (Tabelas 5 e 6).

A triagem para detecção da sequência de inserção IS26 resultou em 100\% de positividade para as cepas produtoras de SHV. Em relação às integrases, uma cepa de K. pneumoniae possuía int2 (FSP276/05, produtora de SHV-12 e CTX-M-59) e nenhuma foi positiva para a pesquisa de int3.

A pesquisa do ambiente genético dos genes $b a_{\mathrm{SHV}}$ foi realizada por meio de reações de PCR com iniciadores para genes tnpA (transposase) da IS26 em conjunto com os iniciadores para $b l a_{\mathrm{SHV}}$.

$\mathrm{O}$ gene bla $_{\mathrm{SHV}-5}$ foi detectado em 12 cepas clínicas, das quais 7 também carreavam genes codificadores dos grupos TEM e/ou CTX-M-2. As amplificações utilizando os iniciadores IS26 R e SHV-5r resultaram em produtos de cerca de $5 \mathrm{~kb}$. A análise do sequenciamento dos mesmos mostrou o gene bla $a_{\mathrm{SHV}-5}\left(5^{\prime}-3^{\prime}\right)$ precedido pelas sequências 3'-5' das regiões abertas de leitura orf41, orf42 e orf43, as quais codificam proteínas hipotéticas, e da IS26 (Figura 13A).

O segundo gene mais abundante nas amostras clínicas foi $b l_{\mathrm{SHV}-12}$, detectado em 6 cepas de K. pneumoniae e uma cepa de E. coli. O produto obtido na mesma reação de PCR realizada para SHV-5 foi de $2 \mathrm{~kb}$, e o sequenciamento do mesmo também revelou a associação de $b l a_{\mathrm{SHV}-12}$ com IS26, a qual neste caso estava inserida 
no promotor de $b l a_{\mathrm{SHV}-12}$ (Figura 13B). Não foram realizadas reações de PCR para verificar se havia relação entre o gene $b l a_{\mathrm{SHV}-12}$ e o integron de classe 2 identificado na cepa FSP276/05, uma vez que o ambiente genético de bla $a_{\mathrm{SHV}-12}$ já havia sido estabelecido.

Não foi possível determinar a associação dos genes $b l a_{\mathrm{SHV}-27}, b l a_{\mathrm{SHV}-28}$, $b l a_{\mathrm{SHV}-45}, b l a_{\mathrm{SHV}-55}$ e $b l a_{\mathrm{SHV}-110}$ com IS26 por meio dos iniciadores e das reações de PCR utilizadas neste estudo.

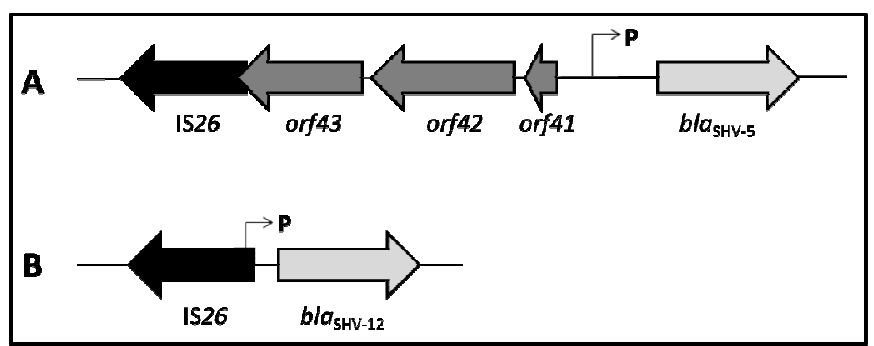

Figura 13. Representação esquemáttica do ambiente genético dos genes $b l a_{\mathrm{SHV}-5} \mathrm{e}$ $b l a_{\mathrm{SHV}-12} . \mathbf{A}$ - Parte da estrutura do transposon (composto)'que continha os genes $b l a_{\text {SHV-5. }}$ B - Parte da estrutura do transposon (composto)'que continha os genes $b l a_{\mathrm{SHV}-12}$, com a IS26 inserida no promotor.

\subsubsection{CTX-M}

Dentre os 30 isolados clínicos com amplificações positivas para genes do grupo bla $_{\mathrm{CTX}-\mathrm{M}-2}, 26(86,7 \%)$ carreavam o gene bla $_{\mathrm{CTX}-\mathrm{M}-2}$, enquanto $3(9,7 \%)$ possuíam bla $a_{\mathrm{CTX}-\mathrm{M}-59}$. Além disso, foi identificado um novo gene do grupo CTX-M-2 denominado $b l a_{\text {CTX-M-131 }}$ (Quadro 7), com a substituição de aminoácido Asp $_{242} \rightarrow$ Gly

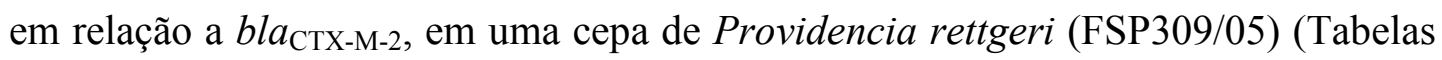
4 e 6$)$. 
Os genes do grupo bla $_{\mathrm{CTX}-\mathrm{M}-2}$ estavam distribuídos em todos os setores do hospital, exceto por UTI Neonatal e Clínica Pediátrica, e foram detectados em todas as espécies clínicas do estudo (Figura 14). A Tabela 4 mostra a distribuição das cepas contendo genes do grupo $b l a_{\mathrm{CTX}-\mathrm{M}-2}$ de acordo com o tipo de infecção em que foram classificadas.

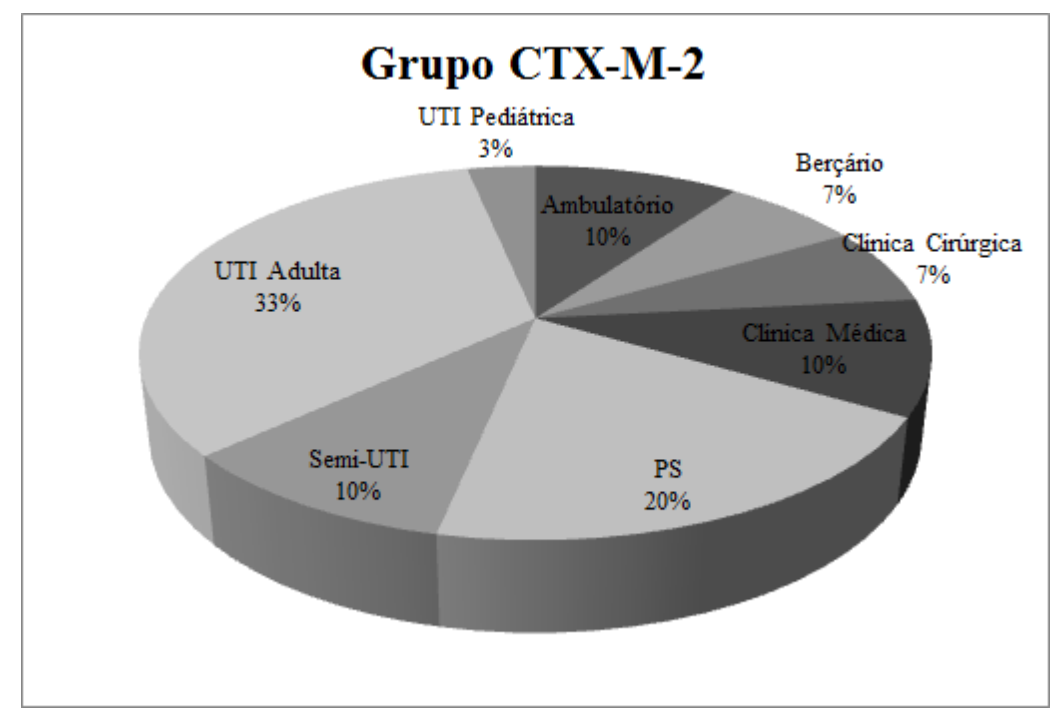

Figura 14. Distribuição das cepas produtoras de ESBL do grupo CTX-M-2, de acordo com o setor hospitalar onde que foram isoladas.

Tabela 4. Número e porcentagem de cepas produtoras de ESBL do grupo CTX-M-2, de acordo com a classificação do tipo de infecção.

\begin{tabular}{ccccc}
\hline Tipo de Infecção & $\begin{array}{c}\text { CTX-M-2 } \\
\mathbf{n}(\%)\end{array}$ & $\begin{array}{c}\text { CTX-M-59 } \\
\text { n (\%) }\end{array}$ & $\begin{array}{c}\text { CTX-M-131 } \\
\text { n (\%) }\end{array}$ & $\begin{array}{c}\text { TOTAL } \\
\text { n (\%) }\end{array}$ \\
\hline $\begin{array}{c}\text { Infecção } \\
\text { Hospitalar }\end{array}$ & $8(26,7)$ & $1(3,3)$ & $1(3,3)$ & $10(33,3)$ \\
$\begin{array}{c}\text { Infecção } \\
\text { Comunitária }\end{array}$ & $5(16,7)$ & $0(0)$ & $0(0)$ & $5(16,7)$ \\
Colonização & $13(43,3)$ & $2(6,7)$ & $0(0)$ & $15(50)$ \\
\hline TOTAL & $26(86,7)$ & $3(10)$ & $1(3,3)$ & $30(100)$ \\
\hline
\end{tabular}


Das 30 cepas clínicas positivas para genes do grupo CTX-M-2, todas foram positivas para a presença da sequência de inserção ISCR1, e destas, 10 (33,3\%) possuíam ISEcp1 e 29 (96,78\%) possuíam IS26.

A triagem das integrases resultou em $28(93,3 \%)$ cepas positivas para int 1 , seis $(20 \%)$ positivas para int 2 e nenhuma para int 3 .

A amplificação utilizando os iniciadores sul Fw e qac Rv (Figura 8) para as cepas contendo $b l a_{\mathrm{CTX}-\mathrm{M}-2}, b l a_{\mathrm{CTX}-\mathrm{M}-59}$ e $b l a_{\mathrm{CTX}-\mathrm{M}-131}$ resultou em amplicons de $3,5 \mathrm{~kb}$ para todas as cepas, cujas sequências foram analisadas, resultando na estrutura de parte do integron de classe 1 complexo, representada pela Figura 15A. A mesma estrutura foi encontrada em 7 espécies: $K$. pneumoniae, $K$. oxytoca, E. coli, $P$. mirabilis, M. morganii, $P$. rettgeri e $P$. stuartii.

Não foram realizadas reações de PCR para verificar se havia relação entre os genes $b l a_{\text {CTX-M-2 }}\left(\right.$ cepas FSP308/05, FSP318/05, FSP325/05 e FSP332/05), bla $a_{\text {CтХ-М- }}$ ${ }_{59}(\mathrm{FSP} 276 / 05)$ e $b l a_{\mathrm{CTX}-\mathrm{M}-131}(\mathrm{FSP} 309 / 05)$ com o integron de classe 2, uma vez que o ambiente genético desses genes já havia sido estabelecido nessas cepas.

Com relação às amostras ambientais, as duas cepas positivas para o grupo CTX-M-1 carreavam o gene bla $_{\mathrm{CTX}-\mathrm{M}-15}$, enquanto que as 5 cepas positivas para o grupo CTX-M-8 possuíam o gene $b l a_{\mathrm{CTX}-\mathrm{M}-8}$ (Tabelas 5 e 6 ).

As cepas contendo $b l a_{\mathrm{CTX}-\mathrm{M}-15}$ foram isoladas da ETE 1, em datas diferentes. A primeira foi uma K. pneumoniae isolada de esgoto tratado em junho de 2009 , e a segunda uma E. coli isolada de esgoto bruto em agosto de 2009. As cepas contendo $b l a_{\mathrm{CTX}-\mathrm{M}-8}$ foram recuperadas de cinco ETEs diferentes (incluindo ETE 1), em datas 
distintas, nos três tipos de amostra: esgoto bruto, esgoto tratado e lodo de esgoto (Tabela 5).

As cepas de E. coli e $K$. pneumoniae que carreavam o gene bla $a_{\mathrm{CTX}-\mathrm{M}-15}$, isoladas da ETE 1, também possuíam os elementos IS26, ISEcp1 e integron de classe 1.

A amplificação utilizando os iniciadores ISEcp1 Fw e CTX-M-1 Rv resultou em um produto de aproximadamente $3 \mathrm{~kb}$, cujo sequenciamento revelou que a ISEcp 1 $\left(5^{\prime}-3^{\prime}\right)$, truncada pela IS26 (3'-5'), estava associada ao gene $b l a_{\mathrm{CTX}-\mathrm{M}-15}\left(5^{\prime}-3^{\prime}\right)$, como representado na Figura 15B.

O gene $b l a_{\text {CTX-M-8 }}$ foi detectado em 5 cepas, isoladas de 5 ETEs diferentes (Tabelas 1 e 5). Os elementos mobilizáveis detectados foram IS26 (100\%), ISEcp1 (80\%) e integrons de classe 1 (80\%). As amplificações dos genes $b a_{\mathrm{CTX}-\mathrm{M}-8}$ com ISEcp 1 pela PCR foram todas negativas, enquanto que com IS26 (IS26 Rv com CTX-M-8 Rv) resultaram em um produto com cerca de $3 \mathrm{~kb}$. O sequenciamento do mesmo revelou a presença da IS26 (3'-5'), truncando a sequência da IS10 (3'-5'), a qual precedia o gene $b l a_{\mathrm{CTX}-\mathrm{M}-8}\left(5^{\prime}-3^{\prime}\right)$ (Figura 15C). 


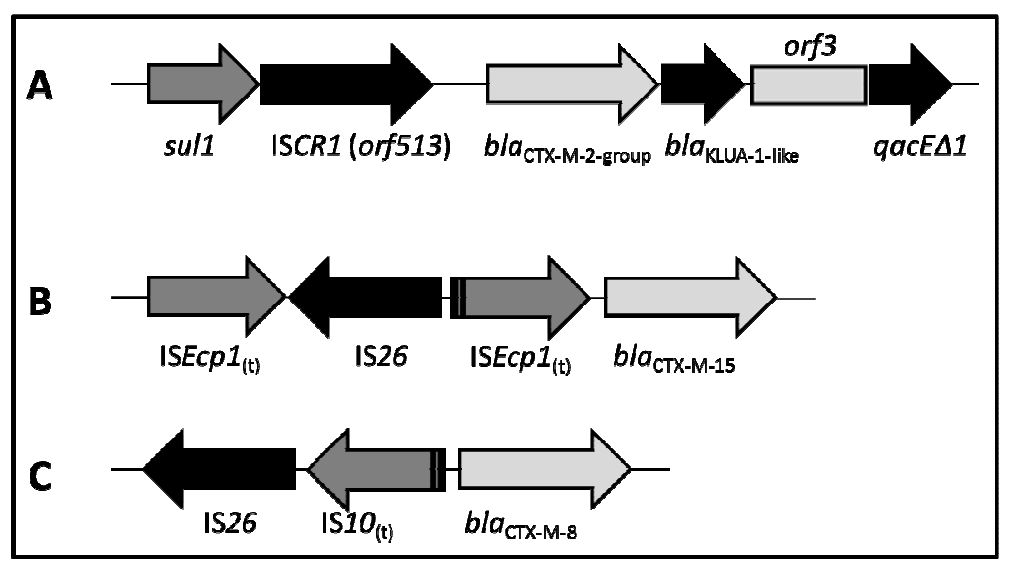

Figura 15. Representação esquemática do ambiente genético dos genes $b l a_{\text {СТХ-M}}$ •

A - Parte da estrutura do integron de classe 1 complexo que continha os genes bla ${ }_{\mathrm{CTX}-\mathrm{M}-2,}$ $b l a_{\mathrm{CTX-M-59}}$ e $b l a_{\text {СТХ-М-131 }}$ (grupo $b l a_{\text {СТХ-М-2 }}$ ). B - Estrutura de ligação entre o gene $b l a_{\mathrm{CTX-M-15}}$ e as sequências de inserção ISEcpl e IS26. C - Estrutura de ligação entre o gene bla ${ }_{\mathrm{CTX}-\mathrm{M}-8} \mathrm{e}$ as sequências de inserção IS26 e IS10. (t) = sequência truncada.

Tabela 5. Cepas ambientais isoladas no estudo, de acordo com o local de isolamento, tipo de amostra, enzimas ESBL detectadas e grupos de incompatibilidade plasmidial (Inc).

\begin{tabular}{ccccc}
\hline Cepa & Local & Amostra & ESBL & Grupo Inc \\
\hline FSP1271/09 & ETE 1 & esgoto tratado & CTX-M-15 e SHV-28 & $\begin{array}{c}\text { não tipável por } \\
\text { PBRT }\end{array}$ \\
FSP1314/09 & ETE 1 & esgoto bruto & CTX-M-15 & FIA e FIB \\
$\mathbf{F S P 1 3 1 2 / 0 9}$ & ETE 1 & esgoto bruto & CTX-M-8 & I1 \\
$\mathbf{F S P 1 3 3 3 / 0 9}$ & ETE 2 & esgoto tratado & CTX-M-8 & I1 \\
$\mathbf{F S P 1 3 5 6 / 0 9}$ & ETE 3 & esgoto bruto & CTX-M-8 & L/M \\
$\mathbf{F S P 1 3 7 3 / 0 9}$ & ETE 4 & lodo de esgoto & CTX-M-8 & I1 e F \\
$\mathbf{F S P 1 4 7 1 / 0 9}$ & ETE 5 & lodo de esgoto & CTX-M-8 & L/M \\
\hline
\end{tabular}




\section{Números de Acesso ao GenBank}

O Quadro 7 apresenta os números de acesso no banco de dados GenBank das sequências de nucleotídeos e aminoácidos para os novos genes relatados no estudo, bem como para os genes relatados pela primeira vez no Brasil.

Quadro 7. Relação dos números de acesso ao banco de dados GenBank para os genes novos e genes relatados pela primeira vez no Brasil.

\begin{tabular}{|c|c|c|}
\hline Número de Acesso & Cepas & Gene \\
\hline HQ877606 & FSP286/05 & bla $a_{\text {TEM-197 }}$ \\
\hline HQ877607 & FSP264/05 & bla $a_{\text {TEM-15 }}$ \\
\hline JN969893 & FSP309/05 & bla $_{\text {CTX-M-131 }}$ \\
\hline HQ877613 & FSP317/05 & bla $_{\text {SHV-55 }}$ \\
\hline HQ877615 & FSP264/05 & bla $_{\text {SHV-110 }}$ \\
\hline
\end{tabular}

\subsection{Tipagem Plasmidial por PBRT}

Entre os isolados clínicos, o grupo de incompatibilidade mais comum foi IncA/C, detectado em todos os setores do hospital, em 17 (37\%) cepas, das quais 14 $(30,4 \%)$ possuíam genes bla $a_{\mathrm{SHV}}$. O segundo grupo mais frequente foi IncF e variantes, detectados em seis dos dez setores do hospital, em $11(24,4 \%)$ cepas contendo tanto genes $b l a_{\mathrm{CTX}-\mathrm{M}-2}$ como $b l a_{\mathrm{SHV}}$ (Tabela 6).

Os demais grupos Inc detectados foram H11 (3), H12 (3), I1 (1), L/M (5), K (1), N (1), P (4), W (1) e Y (2), distribuídos por todos os setores do hospital. Havia cepas contendo 1 a 5 grupos Inc, e $12(26,7 \%)$ cepas não eram tipáveis pelo método de PBRT, das quais $11(24,4 \%)$ possuíam genes do grupo bla $a_{\mathrm{CTX}-\mathrm{M}-2}$ (Tabela 6). 
Com relação aos 7 isolados ambientais, os grupos detectados foram IncF (2), I1 (3) e L/M (2). Um isolado de K. pneumoniae que continha bla $a_{\mathrm{CTX}-\mathrm{M}-15}$ não era tipável pelo método de PBRT (Tabela 5).

\subsection{Detecção e Determinação do Tamanho dos Plasmídios}

A técnica de S1-PFGE revelou a presença de plasmídios de alto peso molecular em $38(84,4 \%)$ isolados clínicos $(48,5$ a $388 \mathrm{~kb})$ e $7(100 \%)$ isolados ambientais (48,5 a 209kb) (Figura 16).

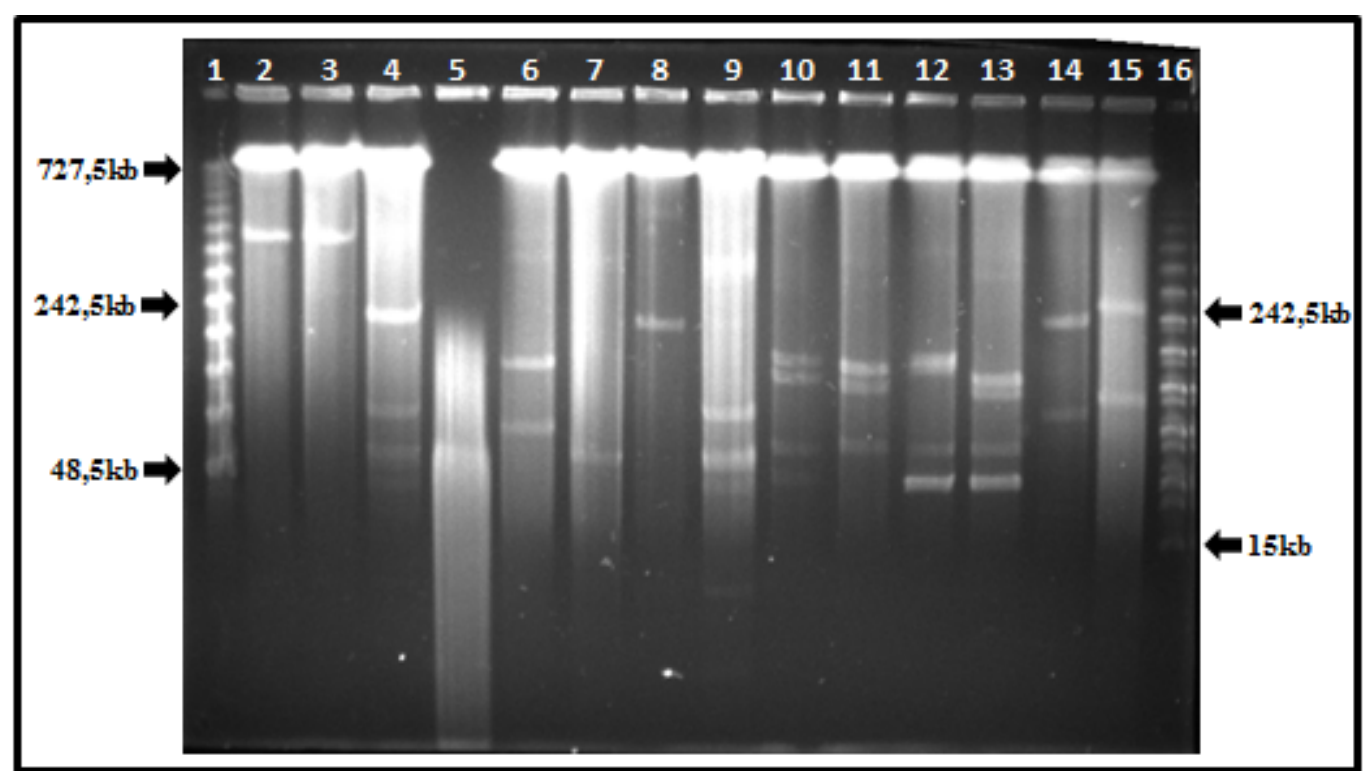

Figura 16. Eletroforese em campo pulsado após a digestão com $\mathrm{S} 1$ nuclease. Linha 1 - marcador de peso molecular Lambda PFG Marker, bandas entre 48,5kb e 727,5kb. Linhas 2 a 15 - amostras de cepas de enterobactérias contendo plasmídios de alto peso molecular. Linha 16 - marcador de peso molecular MidRange PFG Marker I, bandas entre $15 \mathrm{~kb}$ e $242,5 \mathrm{~kb}$. 
Tabela 6. Conjuntos de genes $b l a_{\mathrm{ESBL}}$ e respectivos ambientes genéticos, grupos de incompatibilidade plasmidial (Inc) e plasmídios de alto peso molecular.

\begin{tabular}{|c|c|c|c|c|c|}
\hline bla & Ambiente Genético & \multicolumn{2}{|c|}{ Cepas FSP } & Grupos Inc & Plasmídios de Alto PM (kb) \\
\hline \multicolumn{6}{|l|}{ Clínicas } \\
\hline CTX-M-2 & Integron de Classe 1 Complexo (Figura 11A) & $\begin{array}{l}201 / 05 \\
205 / 05 \\
209 / 05 \\
253 / 05 \\
259 / 05 \\
265 / 05 \\
269 / 05 \\
308 / 05 \\
314 / 05 \\
316 / 05 \\
318 / 05 \\
325 / 05 \\
326 / 05 \\
328 / 05 \\
332 / 05\end{array}$ & $\begin{array}{l}\text { Proteus mirabilis } \\
\text { Escherichia coli } \\
\text { Morganella morganii } \\
\text { Klebsiella pneumoniae } \\
\text { Klebsiella pneumoniae } \\
\text { Escherichia coli } \\
\text { Klebsiella pneumoniae } \\
\text { Morganella morganii } \\
\text { Escherichia coli } \\
\text { Klebsiella pneumoniae } \\
\text { Providencia stuartii } \\
\text { Morganella morganii } \\
\text { Escherichia coli } \\
\text { Escherichia coli } \\
\text { Morganella morganii }\end{array}$ & $\begin{array}{l}\text { A/C FIC } \\
\text { F FIB H12 P Y } \\
\text { não tipável } \\
\text { não tipável } \\
\text { não tipável } \\
\text { A/C FIA FIB } \\
\mathrm{K} \\
\text { não tipável } \\
\text { H11 P } \\
\text { não tipável } \\
\text { A/C W } \\
\text { não tipável } \\
\text { F FIB } \\
\text { F FIB } \\
\text { não tipável }\end{array}$ & $\begin{array}{l}179 \\
48,5 \text { / } 97 \text { / } 291 \\
\text { não possui } \\
>339,5 \\
>339,5 \\
97 \text { / 145,5 / 339,5 / } 388 \\
194 \text { / 436,5 } \\
\text { não possui } \\
97 / 242,5 \\
242,5 \\
160,5 ; 339,5 \\
\text { não possui } \\
145,5 \\
145,5 \\
\text { não possui }\end{array}$ \\
\hline $\begin{array}{l}\text { CTX-M-2 } \\
\text { SHV-5 }\end{array}$ & $\begin{array}{l}\text { Integron de Classe } 1 \text { Complexo (Figura 11A) } \\
\text { IS26 e orf41, orf42 e orf } 43 \text { (Figura 10A) }\end{array}$ & $\begin{array}{l}246 / 05 \\
262 / 05 \\
306 / 05\end{array}$ & $\begin{array}{l}\text { Escherichia coli } \\
\text { Klebsiella pneumoniae } \\
\text { Escherichia coli }\end{array}$ & $\begin{array}{l}\mathrm{A} / \mathrm{C} \\
\mathrm{F} \\
\mathrm{H} 11\end{array}$ & $\begin{array}{l}82 / 145,5 \\
48,5 / 97 / 194 \\
130,5 / 209\end{array}$ \\
\hline $\begin{array}{l}\text { CTX-M-2 } \\
\text { SHV-12 }\end{array}$ & $\begin{array}{l}\text { Integron de Classe } 1 \text { Complexo (Figura 11A) } \\
\text { IS26 inserida no promotor (Figura 10B) }\end{array}$ & $220 / 05$ & Klebsiella pneumoniae & $\mathrm{A} / \mathrm{C}$ & 48,5 / 97 / 145,5 / 209 \\
\hline $\begin{array}{l}\text { CTX-M-2 } \\
\text { SHV-28 }\end{array}$ & $\begin{array}{l}\text { Integron de Classe } 1 \text { Complexo (Figura 11A) } \\
\text { desconhecido }\end{array}$ & $\begin{array}{l}202 / 05 \\
211 / 05 \\
234 / 05 \\
324 / 05 \\
\end{array}$ & $\begin{array}{l}\text { Klebsiella pneumoniae } \\
\text { Klebsiella pneumoniae } \\
\text { Klebsiella pneumoniae } \\
\text { Klebsiella oxytoca }\end{array}$ & $\begin{array}{l}\text { não tipável } \\
\text { A/C } \\
\text { A/C } \\
\text { FIIs H11 } \\
\end{array}$ & $\begin{array}{l}145,5 /<291 \\
112 / 194 \\
48,5 / 82 / 145,5 \\
145,5 / 242,5 / 388 \\
\end{array}$ \\
\hline $\begin{array}{l}\text { CTX-M-2 } \\
\text { SHV-28 SHV-55 }\end{array}$ & $\begin{array}{l}\text { Integron de Classe } 1 \text { Complexo (Figura 11A) } \\
\text { desconhecidos }\end{array}$ & $317 / 05$ & Klebsiella pneumoniae & $\mathrm{A} / \mathrm{C}$ & $63,5 / 112$ / 209 \\
\hline $\begin{array}{l}\text { CTX-M-2 } \\
\text { SHV-27 SHV-45 }\end{array}$ & $\begin{array}{l}\text { Integron de Classe } 1 \text { Complexo (Figura 11A) } \\
\text { desconhecidos }\end{array}$ & $208 / 05$ & Klebsiella pneumoniae & $\mathrm{A} / \mathrm{C}$ & $97 / 145,5$ \\
\hline $\begin{array}{l}\text { CTX-M-2 } \\
\text { SHV-110 } \\
\text { TEM- } 15^{\text {a }} \\
\end{array}$ & $\begin{array}{l}\text { Integron de Classe } 1 \text { Complexo (Figura 11A) } \\
\text { desconhecido } \\
\text { Tn2* (Figura 9A) }\end{array}$ & $264 / 05$ & Klebsiella pneumoniae & não tipável & $130,5 / 291$ \\
\hline $\begin{array}{l}\text { CTX-M-59 } \\
\text { SHV-12 }\end{array}$ & $\begin{array}{l}\text { Integron de Classe } 1 \text { Complexo (Figura 11A) } \\
\text { IS26 inserida no promotor (Figura 10B) }\end{array}$ & $276 / 05$ & Klebsiella pneumoniae & $\mathrm{A} / \mathrm{C}$ & $82 / 145,5 / 160,5$ \\
\hline
\end{tabular}




\begin{tabular}{|c|c|c|c|c|c|}
\hline bla & Ambiente Genético & \multicolumn{2}{|c|}{ Cepas FSP } & \multirow{2}{*}{$\begin{array}{l}\text { Grupos Inc } \\
\mathrm{A} / \mathrm{C}\end{array}$} & \multirow{2}{*}{$\begin{array}{l}\text { Plasmídios de Alto PM (kb) } \\
160,5 / 209\end{array}$} \\
\hline $\begin{array}{l}\text { CTX-M-59 } \\
\text { SHV-27 }\end{array}$ & $\begin{array}{l}\text { Integron de Classe } 1 \text { Complexo (Figura 11A) } \\
\text { desconhecido }\end{array}$ & $248 / 05$ & Klebsiella pneumoniae & & \\
\hline $\begin{array}{l}\text { CTX-M-59 } \\
\text { SHV-110 }\end{array}$ & $\begin{array}{l}\text { Integron de Classe } 1 \text { Complexo (Figura 11A) } \\
\text { desconhecido }\end{array}$ & $237 / 05$ & Klebsiella pneumoniae & não tipável & não possui \\
\hline CTX-M-131 & Integron de Classe 1 Complexo (Figura 11A) & $309 / 05$ & Providencia rettgeri & não tipável & $112 / 145,5$ \\
\hline SHV-5 & IS 26 e $\operatorname{orf} 41$, orf 42 e orf 43 (Figura 10A) & $\begin{array}{l}224 / 05 \\
225 / 05 \\
226 / 05 \\
243 / 05 \\
274 / 05 \\
275 / 05 \\
295 / 05 \\
305 / 05\end{array}$ & $\begin{array}{l}\text { Klebsiella pneumoniae } \\
\text { Klebsiella pneumoniae } \\
\text { Klebsiella pneumoniae } \\
\text { Klebsiella pneumoniae } \\
\text { Klebsiella pneumoniae } \\
\text { Klebsiella pneumoniae } \\
\text { Klebsiella pneumoniae } \\
\text { Klebsiella pneumoniae }\end{array}$ & $\begin{array}{l}\text { FIIs } \\
\text { não tipável } \\
\text { FIIs } \\
\text { L/M } \\
\text { L/M } \\
\text { A/C } \\
\text { A/C } \\
\text { A/C }\end{array}$ & $\begin{array}{l}48,5 \text { / } 97 \text { / } 194 \text { / } 209 \\
48,5 \text { / } 97 \\
48,5 \text { / } 97 \text { / } 209 \\
48,5 \text { / } 97 \text { / } 291 \\
48,5 \text { / } 97 \text { / } 291 \\
48,5 \text { / } 82 \text { / 145,5 / 160,5 } \\
48,5 \text { / } 82 \text { / 130,5 / 145,5 / } 291 \\
97 \text { / } 194\end{array}$ \\
\hline SHV-12 & IS26 inserida no promotor (Figura 10B) & $\begin{array}{l}214 / 05 \\
227 / 05 \\
263 / 05 \\
267 / 05 \\
315 / 05\end{array}$ & $\begin{array}{l}\text { Klebsiella pneumoniae } \\
\text { Klebsiella pneumoniae } \\
\text { Klebsiella pneumoniae } \\
\text { Escherichia coli } \\
\text { Klebsiella pneumoniae }\end{array}$ & $\begin{array}{l}\mathrm{A} / \mathrm{C} \mathrm{H} 12 \\
\mathrm{~A} / \mathrm{C} \\
\mathrm{A} / \mathrm{C} \mathrm{H} 12 \\
\mathrm{~L} / \mathrm{M} \mathrm{P} \mathrm{Y} \\
\text { FIIs L/M }\end{array}$ & $\begin{array}{l}\text { não possui } \\
194 \text { / } 209 \\
\text { não possui } \\
48,5 \\
48,5 \text { / } 63,5 \text { / } 97 \text { / } 112\end{array}$ \\
\hline $\begin{array}{l}\text { SHV-5 } \\
\text { TEM-197 }\end{array}$ & $\begin{array}{l}\text { IS26 e orf41, orf42 e orf } 43 \text { (Figura 10A) } \\
\text { Tn3 (Figura 9B) }\end{array}$ & $287 / 05$ & Klebsiella pneumoniae & $\mathrm{A} / \mathrm{C}$ & $48,5 / 82$ / $179 />291$ \\
\hline TEM- $197^{\mathrm{b}}$ & Tn3 (Figura 9B) & $286 / 05$ & Klebsiella pneumoniae & $\mathrm{L} / \mathrm{M}$ & $>63,5 / 97 / 112$ \\
\hline \multicolumn{6}{|l|}{ Ambientais } \\
\hline CTX-M-8 & IS26 e IS10 (Figura 11C) & $\begin{array}{l}1312 / 09 \\
1333 / 09 \\
1356 / 09 \\
1373 / 09 \\
1471 / 09\end{array}$ & $\begin{array}{l}\text { Escherichia coli } \\
\text { Escherichia coli } \\
\text { Klebsiella pneumoniae } \\
\text { Escherichia coli } \\
\text { Enterobacter cloacae }\end{array}$ & $\begin{array}{l}\mathrm{I} 1 \\
\mathrm{I} 1 \\
\mathrm{~L} / \mathrm{M} \\
\mathrm{I} 1 \mathrm{~F} \\
\mathrm{~L} / \mathrm{M}\end{array}$ & $\begin{array}{l}48,5 \\
82 \\
63,5 / 160,5 \\
97 / 130,5 \\
63,5 / 145,5\end{array}$ \\
\hline CTX-M-15 & ISEcp1 e IS26 (Figura 11B) & $1314 / 09$ & Escherichia coli & FIA FIB & 112 \\
\hline $\begin{array}{l}\text { CTX-M-15 } \\
\text { SHV-28 } \\
\end{array}$ & $\begin{array}{l}\text { ISEcp1 e IS26 (Figura 11B) } \\
\text { desconhecido }\end{array}$ & $1271 / 09$ & Klebsiella pneumoniae & não tipável & $<130,5 / 209$ \\
\hline
\end{tabular}

${ }^{\text {a }}$ Primeiro relato no Brasil; ${ }^{\mathrm{b}}$ Novos genes ESBL; PM - peso molecular. 


\section{DISCUSSÃO}

A resistência antimicrobiana é classificada pela Organização Mundial da Saúde como uma ameaça à saúde pública, impulsionada tanto pelo uso adequado como inadequado de medicamentos anti-infecciosos utilizados na saúde humana e animal bem como na produção de alimentos e, ainda, com medidas inapropriadas para controlar a disseminação de infecções (OMS 2013). É um problema que aumenta a morbidade, a mortalidade e os custos de tratamento (HAWKEY \& JONES 2009). A resistência em amostras e ambientes diversos além da clínica é o foco principal das pesquisas atualmente, uma vez que a presença de genes de resistência na natureza e nos alimentos pode levar à disseminação dos mesmos para toda a população, tornando o tratamento das infecções ainda mais desafiador do que já se apresenta (GARCIA-ALVAREZ et al. 2012, STALDER et al. 2012).

O índice de $\beta$-lactamases de espectro estendido - uma das formas mais combatidas de resistência em bactérias Gram negativas no mundo - em $K$. pneumoniae e E. coli na América Latina é 50\% e 26\%, respectivamente (GALES et al. 2012), e está abaixo apenas de países superpopulosos como a Índia e a China, com $80 \%$ e $60 \%$ em média para as duas espécies juntas (LIVERMORE 2012). De acordo com os últimos dados referentes à América Latina divulgados pelo programa mundial de vigilância à resistência SENTRY (SENTRY Antimicrobial Surveillance Program), os índices de ESBL em E. coli e K. pneumoniae isoladas no Brasil são de 12,8\% e 49,9\%, respectivamente (GALES et al. 2012).

Os resultados obtidos no presente estudo evidenciam a disseminação de genes codificadores de ESBL em uma instituição pública de saúde e em estações de 
tratamento de esgoto da Grande São Paulo. O foco principal deste estudo foi demonstrar que tanto a identificação de genes codificadores de ESBL como a determinação de seu ambiente genético são ferramentas importantes na análise da disseminação da resistência, uma vez que se o gene está presente em cepas de espécies ou perfis genéticos diferentes, e/ou foi detectado em locais distintos, ou ainda fizer parte de uma estrutura genética mobilizável, sugere-se que possa ter havido algum tipo de evento de transferência horizontal que levou à disseminação do mesmo.

A razão deste estudo ter recuperado apenas sete cepas ambientais produtoras de ESBL, dentre 200 pesquisadas, pode ter sido devido ao fato de que no ambiente estas cepas estejam diluídas, ou seja, em densidades menores, e portanto mais difíceis de serem isoladas. Além da baixa recuperação de cepas resistentes nas amostras ambientais, as plataformas genéticas detectadas em cepas clínicas e naquelas isoladas de amostras de esgoto foram distintas, apesar do fato das ETEs receberem esgotos contendo dejetos oriundos tanto de instituições de saúde como da população em geral. Isto pode ter ocorrido devido à diferença entre as épocas de isolamento das cepas, que tiveram um intervalo de 4 anos. Outro fator responsável por esses resultados pode ter sido o fato de que as amostras provenientes das ETEs foram cultivadas, com posterior isolamento das cepas. $\mathrm{O}$ ambiente contém uma vasta variedade de espécies bacterianas, e os métodos de cultivo só permitem o isolamento de uma pequena fração delas, em torno de $1 \%$. Atualmente, a combinação de métodos de cultivo com técnicas baseadas no estudo do metagenoma do ambiente tem evitado esta limitação e evidenciado a disseminação da resistência de uma forma mais próxima à realidade (STALDER et al. 2012). 


\subsection{Genes bla $\mathrm{TEM}$}

Os genes codificadores das beta-lactamases do grupo TEM identificados neste estudo, na sua grande maioria, não codificam enzimas ESBL (bla $a_{\mathrm{TEM}-1 \mathrm{~A}}$, $\left.b l a_{\mathrm{TEM}-1 \mathrm{~B}}\right)$, exceto por $b l a_{\mathrm{TEM}-15}$ e $b l a_{\mathrm{TEM}-197}$. Os genes $b l a_{\mathrm{TEM}-1 \mathrm{~A}}$ e $b l a_{\mathrm{TEM}-1 \mathrm{~B}}$ codificam penicilinases precursoras das ESBL, e diferem entre si apenas por mutações silenciosas em seus genes (BRADFORD 2001). Uma vez que todas as cepas incluídas no estudo são produtoras de ESBL, a maioria das cepas positivas para os genes $b l a_{\mathrm{TEM}}$ estavam associadas a outros genes $b l a_{\mathrm{ESBL}}$.

A enzima TEM-15 difere de TEM-1 por duas substituições de aminoácidos $\left(\mathrm{Glu}_{104} \rightarrow\right.$ Lys e $\mathrm{Gly}_{238} \rightarrow$ Ser) e de TEM-3 por apenas uma substituição ( $\left.\operatorname{Lys}_{39} \rightarrow \mathrm{Gln}\right)$, fatores que aumentam sua atividade catalítica e a caracterizam como ESBL. A produção de TEM-15 já foi relatada em diversos trabalhos na Europa e Ásia, em espécies da família Enterobacteriaceae (SHANNON et al. 1998; ARPIN et al. 2003; KIM et al. 2004; SEGATORE et al. 2004; ARPIN et al. 2005; ZARNAYOVÁ et al. 2005; CACCAMO et al. 2006; CHOUCHANI et al. 2007; PERILLI et al. 2011) e em Haemophilus influenzae (TRISTRAM et al. 2008), em isolados de ambientes hospitalares e na comunidade. Contudo, de acordo com a literatura consultada, este é o primeiro relato de TEM-15 na América Latina, o que mostra sua disseminação para mais um continente.

Os resultados deste estudo mostram que o gene $b l a_{\mathrm{TEM}-15}$ está associado a um transposon descrito na literatura como $\mathrm{Tn} 2 *$, o qual possui alta similaridade com $\operatorname{Tn} 1$ e Tn3, e cujo gene tnpR é quase idêntico ao do Tn2. O elemento Tn2* é um transposon mosaico que surgiu após eventos de recombinação homóloga seguida de 
recombinação mediada pela resolvase, e foi identificado em um plasmídio de alto peso molecular contendo genes de resistência a antimicrobianos e mercúrio (PARTRIDGE \& HALL 2004). Sendo assim, o gene bla $a_{\mathrm{TEM}-15}$ identificado neste estudo está associado a um elemento mobilizável que poderia estar localizado em um plasmídio de alto peso molecular, uma vez que a cepa de $K$. pneumoniae FSP264/05 possui plasmídios de $130,5 \mathrm{~kb}$ e $291 \mathrm{~kb}$. Outro fato relevante em relação a esta cepa é que também possui os genes $b l a_{\mathrm{SHV}-110}$ e $b l a_{\mathrm{CTX}-\mathrm{M}-2}$, sendo que o último foi detectado em diversas espécies e setores diferentes do hospital em estudo, o que sugere que foi disseminado por meio de transferência horizontal, e portanto poderia carrear os genes bla $_{\mathrm{TEM}-15}$ e bla $a_{\mathrm{SHV}-110}$ no mesmo plasmídio. Sendo assim, mesmo que este estudo não tenha determinado a localização dos genes bla, é possível que possa ocorrer a mobilização dos mesmos para outras bactérias em caso de pressão seletiva de antimicrobianos.

A nova enzima TEM-197, com a substituição de aminoácidos $\mathrm{Ala}_{184} \rightarrow$ Val em relação à TEM-15, foi identificada em dois isolados de $K$. pneumoniae não relacionados geneticamente (FSP286/05 e FSP287/05), de dois pacientes distintos, e de unidades hospitalares diferentes. TEM-197 foi identificada tanto em combinação com SHV-5 (Tabela 6), expressando valores altos de CIM para cefalosporinas de terceira geração e aztreonam $(>256 \mu \mathrm{g} / \mathrm{mL})$, como isoladamente em outra cepa, com valores mais baixos de CIM, mas ainda altos o suficiente para caracterizar esta cepa como resistente a ceftazidima $(\mathrm{CIM}=32 \mu \mathrm{g} / \mathrm{mL})$ e cefotaxima $(\mathrm{CIM}=12 \mu \mathrm{g} / \mathrm{mL})$, e com sensibilidade intermediária ao aztreonam $(\mathrm{CIM}=12 \mu \mathrm{g} / \mathrm{mL})$, e positiva para o teste de produção fenotípica de ESBL (Tabela 1) (CLSI 2012). Contudo, estudos 
adicionais serão necessários para a caracterização bioquímica completa da nova enzima.

O gene bla $a_{\mathrm{TEM}-197}$ esta associado ao elemento Tn3, o qual possui "imunidade de transposição" e faz "transposição de extremidade única", ou seja, possui um mecanismo regulatório para que não haja mais de duas cópias no mesmo plasmídio, ao mesmo tempo que consegue se mobilizar a partir de uma só extremidade (CARATOLLI 2009; TOLEMAN \& WALSH 2011). As duas cepas produtoras de TEM-197 possuíam plasmídios de grupos Inc diferentes (IncA/C e IncL/M), porém ensaios de localização e mobilidade do gene bla $a_{\mathrm{TEM}-197}$ seriam necessários para afirmar se estão contidos nesses plasmídios especificamente. O fato de ambas as cepas possuírem diversos plasmídios de alto peso molecular, porém, reforça a suspeita de que $b l a_{\mathrm{TEM}-197}$ tenha sido mobilizado por transferência horizontal.

\subsection{Genes bla $\mathrm{SHV}$}

A família SHV de enzimas ESBL é predominante em estudos de cepas resistentes na América do Sul e pode estar presente em nosso continente desde antes da primeira descrição de uma ESBL (KLIEBE et al. 1985, VILLEGAS et al. 2008). Em relação à sua distribuição mundial, muitas variantes foram descritas apenas uma ou duas vezes, porém SHV-2, -5, -11 e -12 estão disseminadas em muitos países (PATERSON \& BONOMO 2005; LIVERMORE 2012). Há um consenso de que a espécie $K$. pneumoniae possui naturalmente genes $b l a_{\mathrm{SHV}-1}$ ou variantes do mesmo (BABINI \& LIVERMORE 2000; CHAVES et al. 2001; HOWARD et al. 2002; HAMMOND et al. 2008), e no presente estudo apenas uma de 31 cepas não continha genes do grupo bla ${ }_{\mathrm{SHV}}$. Apenas duas destas cepas possuíam bla $a_{\mathrm{SHV}-1}$, enquanto que as 
outras 29 possuíam variantes deste gene, como $b l a_{\mathrm{SHV}-5}, b l a_{\mathrm{SHV}-11}, b l a_{\mathrm{SHV}-12}, b l a_{\mathrm{SHV}-}$ ${ }_{27}, b l a_{\mathrm{SHV}-28}, b l a_{\mathrm{SHV}-45}, b l a_{\mathrm{SHV}-55}$ e $b l a_{\mathrm{SHV}-110}$, todos com exceção de $b l a_{\mathrm{SHV}-11}$ codificando enzimas de espectro estendido.

O fato do gene $b l a_{\mathrm{SHV}-1}$ não ter sido detectado em todas as cepas de $K$. pneumoniae corrobora com os estudos realizados por CHAVES et al. (2001) e HOWARD et al. (2002), os quais utilizam hibridização/PCR-RFLP e análise de sequenciamento, respectivamente, para a identificação dos genes $b l a_{\mathrm{SHV}-1}$ de coleções de K. pneumoniae, e de forma semelhante a este estudo detectaram apenas variantes de $b l a_{\mathrm{SHV}-1}$ em algumas cepas. Em relação à única cepa de $K$. pneumoniae (FSP286/05) da qual não foi possível amplificar genes do grupo bla $a_{\mathrm{SHV}}$ com a metodologia aplicada neste trabalho, estudos futuros com novos iniciadores e/ou diferentes reações de PCR poderiam elucidar esta questão.

De todas as enzimas SHV identificadas, SHV-5 foi predominante e é de fato relatada na literatura como a mais disseminada na América Latina, e seu espectro estendido se deve às substituições de aminoácidos $\mathrm{Leu}_{205} \rightarrow \mathrm{Arg}$ e $\mathrm{Glu}_{240} \rightarrow \mathrm{Lys}$ em relação à SHV-3 (BILLOT-KLEIN et al. 1990; VILLEGAS et al. 2008). O gene $b l a_{\text {SHV-5 }}$ foi identificado isoladamente em 8 cepas de $K$. pneumoniae, provenientes de três unidades hospitalares pediátricas (UTI Neonatal, Berçário e Clínica Pediátrica). Além disso, foi identificado também em associação com outros genes bla $a_{\mathrm{ESBL}}$, tanto em K. pneumoniae como em E. coli, o que mostra seu potencial de mobilidade entre as cepas (Tabelas 1 e 6$)$.

A enzima SHV-12 difere da SHV-5 apenas pela substituição Leu $_{35} \rightarrow \mathrm{Gln}$ (NÜESCH-INDERBINEM et al. 1997), e foi descrita pela primeira vez no Brasil por 
TOLLENTINO et al. (2011), em cepas clínicas de K. pneumoniae. Em nosso estudo, foi identificada em $K$. pneumoniae e E. coli, em cinco setores hospitalares (Ambulatório, Pronto Socorro, Clínica Médica, Clínica Cirúrgica e UTI Pediátrica), e portanto também demonstrou seu potencial de disseminação nas cepas isoladas na instituição (Tabelas 1 e 6).

Os ambientes genéticos onde estavam contidos os genes $b_{\mathrm{SHV}-5}$ (Figura 13A) e bla $a_{\mathrm{SHV}-12}$ (Figura 13B) são conhecidos como "grande transposon" e "pequeno transposon", respectivamente, como já descrito anteriormente. Portanto, possuem promotores fortes frequentemente identificados em plasmídios, tanto de $K$. pneumoniae como outras Enterobacteriaceae, o que sugere que sua localização seja plasmidial, uma vez que a expressão do gene no cromossomo não seria suficiente para resultar no fenótipo ESBL (HAMMOND et al. 2008; TURNER et al. 2009). Sendo assim, apesar da localização dos genes não estar definida neste estudo, é provável que $b l a_{\mathrm{SHV}-5}$ e $b l a_{\mathrm{SHV}-12}$, especialmente nas cepas que não possuem outros genes ESBL, estejam localizados em plasmídios.

Plasmídios do grupo IncA/C, bem como plasmídios de 48,5kb e $97 \mathrm{~kb}$, foram detectados com frequência nas cepas produtoras de SHV-5 e SHV-12, porém não é possível afirmar que estejam associados e esses genes. Para isso, seriam necessários ensaios de mobilização e/ou localização genética.

A ESBL SHV-27 foi descrita no Brasil em 2001, em uma cepa clínica de $K$. pneumoniae, e possui uma substituição de aminoácido Gly $\mathrm{y}_{160} \rightarrow$ Asp, além de algumas mutações genéticas silenciosas, em relação à SHV-1 (CORKILL et al. 2001). A enzima tem sido relatada em alguns países africanos e asiáticos, inclusive 
em amostras isoladas de animais (LIN et al. 2006; KIRATISIN et al. 2008; HAMMAD \& SHIMAMOTO 2011; ZOU et al. 2011; JIANG et al. 2012), porém não teve mais relatos na América Latina. Neste estudo, foi identificada em 2 cepas de K. pneumoniae de setores hospitalares distintos, associada a CTX-M-59 ou CTX-M$2+$ SHV-45. O gene bla $a_{\mathrm{SHV}-45}$ foi descrito em 2002 também no Brasil (AF547625) e codifica uma ESBL com a substituição Gly $_{160} \rightarrow$ Asp (como a SHV-27), Gly S238 $_{2} \rightarrow$ Ser e $\mathrm{Glu}_{239} \rightarrow$ Lys (como a SHV-5). Aparentemente, com exceção de bla ${ }_{\mathrm{CTX}-\mathrm{M}-2}$, apenas genes descritos no Brasil estavam presentes nestas cepas, e curiosamente ambas possuíam plasmídios do grupo $\mathrm{Inc} A / \mathrm{C}$, o qual foi o mais frequente entre as cepas clínicas do estudo (37\%) e recentemente foi relatado como possível agente

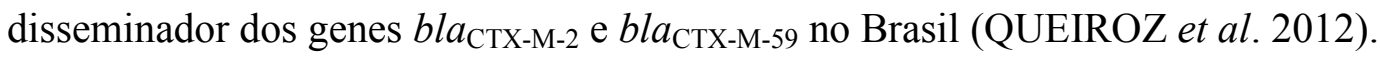

A ESBL SHV-28 possui as substituições $\operatorname{Tyr}_{7} \rightarrow$ Phe e Asp ${ }_{156} \rightarrow$ Gly em relação à SHV-27, com preferência para os substratos cefotaxima e ceftazidima (JEMIMA \& VERGHESE 2009). No Brasil, foi relatada pela primeira vez em 2011, em uma cepa clínica de $K$. pneumoniae que não expressava o fenótipo ESBL (VERAS et al. 2011). No presente estudo, $b l a_{\mathrm{SHV}-28}$ foi detectado em cepas clínicas de K. pneumoniae e K. oxytoca, associado aos genes $b_{l} a_{\mathrm{CTX}-\mathrm{M}-2}$ e $b l a_{\mathrm{SHV}-55}$. A enzima SHV-28 também foi detectada em associação com CTX-M-15 em uma cepa de $K$. pneumoniae isolada do esgoto tratado da ETE 1 (FSP1271/09), sendo este o primeiro relato desta enzima em amostras ambientais. Ao contrário da cepa descrita por VERAS et al. (2011), as cepas deste estudo possuíam o fenótipo ESBL e CIM maiores para ceftazidima (de $1 \mu \mathrm{g} / \mathrm{mL}$ para 3 a $>256 \mu \mathrm{g} / \mathrm{mL}$ ) e cefotaxima (de $0,5 \mu \mathrm{g} / \mathrm{mL}$ para 32 a $>256 \mu \mathrm{g} / \mathrm{mL}$ ), uma vez que estavam todas associadas a genes bla $a_{\text {СТХ-м. }}$ 
Apesar de não ter sido possível determinar o ambiente genético dos genes $b l a_{\mathrm{SHV}-28}$, é possível que tenha havido a disseminação dos mesmos da clínica para o ambiente, por meio do descarte de esgoto hospitalar. Não se pode descartar, entretanto, a hipótese do gene ter sido levado da natureza ou da comunidade para o ambiente hospitalar, ou ainda de ter surgido em eventos independentes, como mutações de outros genes $b a_{\mathrm{SHV}}$ em cepas presentes nos dois locais (hospital e ETE 1). Uma vez que a cepa ambiental FSP1271/09, que também continha o gene bla $a_{\mathrm{CTX}}$ M-15, não é clone de nenhuma das cepas clínicas produtoras de SHV-28, os plasmídios de alto peso molecular detectados em todas essas cepas podem ter sido os responsáveis pela disseminação, caso essa tenha realmente ocorrido. $\mathrm{O}$ fato deste gene ter sido encontrado em uma amostra de esgoto tratado demonstra que o reuso dos produtos oriundos das ETEs necessita de protocolos que incluam a pesquisa de genes de resistência, para que seja possível evitar a disseminação para outras fontes.

O presente estudo identificou também o gene $b l a_{\text {SHV-55, o qual codifica a }}$ enzima SHV-55 que possui três substituições de aminoácidos em relação à SHV-1, $\mathrm{Tyr}_{7} \rightarrow$ Phe, Gly $238 \rightarrow$ Ser e Glu $_{239} \rightarrow$ Lys, sendo que Gly Ge $_{238} \rightarrow$ Ser é a mesma substituição que ocorre na SHV-5, e provavelmente é a responsável pelos altos valores de CIM para cefalosporinas de terceira e quarta geração e aztreonam. A cepa clínica de K. pneumoniae FSP317/05, que carreava os genes codificadores de SHV28, SHV-55 e CTX-M-2, possuía valores de CIM maiores que $256 \mu \mathrm{g} / \mathrm{mL}$ para ceftazidima, cefotaxima, cefepime, aztreonam e piperacilina-tazobactam (Tabela 1). Além disso, a cepa possuía três plasmídios de alto peso molecular, os quais poderiam mobilizar todos estes genes em caso de pressão seletiva de antimicrobianos. Este é o 
primeiro relato de SHV-55 fora de Portugal, mostrando a disseminação de mais um gene bla $a_{\mathrm{ESBL}}$ no Brasil (MENDONÇA et al. 2008; MENDONÇA et al. 2009).

A ESBL SHV-110 possui a substituição $\mathrm{Gly}_{156} \rightarrow$ Asp e foi identificada em uma cepa de $K$. pneumoniae isolada de queijo egípcio no Japão (HAMMAD et al. 2009). Recentemente, foi detectada pela primeira vez em uma cepa clínica, um isolado de K. pneumoniae no Marrocos (BARGUIGUA et al. 2012). Portanto este é o terceiro relato de SHV-110 no mundo. No presente estudo, a enzima foi identificada em duas situações distintas, em cepas de K. pneumoniae: a primeira associada a CTX-M-59, em uma cepa isolada na UTI Semi-Intensiva, em outubro de 2004 (FSP237/05); no segundo caso, SHV-110 estava associada a TEM-15 e CTXM-2, em uma cepa isolada na UTI Adulta, dois meses depois (FSP264/05), com valores de CIM mais altos que no primeiro caso para ceftazidima (de 8 para $64 \mu \mathrm{g} / \mathrm{mL}$ ) e cefepime (de 64 para $256 \mu \mathrm{g} / \mathrm{mL}$ ). A primeira cepa não possuía plasmídios de alto peso molecular (possuía apenas um plasmídio de aproximadamente $9 \mathrm{~kb}$ detectado pela extração por kit comercial - dados não apresentados) e teve resultado negativo para os grupos Inc detectáveis pela técnica de PBRT, enquanto que a segunda, também negativa para PBRT, possuía plasmídios de $130,5 \mathrm{~kb}$ e $291 \mathrm{~kb}$. Não é possível saber, com estes resultados, se ocorreram dois casos isolados de detecção do gene bla $a_{\mathrm{SHV}-110}$, o que seria raro, ou se a primeira cepa recebeu plasmídios por transferência horizontal e passou por algum evento de mobilização, por meio dos elementos móveis associados aos demais genes detectados nestas cepas, e transferiu o plasmídio contendo $b l_{\mathrm{SHV}-110}$ para a segunda cepa onde foi detectado. 
Uma vez que não foi possível determinar o ambiente genético dos genes bla $_{\mathrm{SHV}-27}, b l a_{\mathrm{SHV}-28}, b l a_{\mathrm{SHV}-45}$, bla $_{\mathrm{SHV}-55}$ e $b l a_{\mathrm{SHV}-110}$, seriam necessários ensaios de mobilização genética para determinar se estão localizados em plasmídios ou no cromossomo dos isolados de Klebsiella spp. Contudo, todas essas cepas exceto FSP237/05 possuíam plasmídios de alto peso molecular (48,5kb a $388 \mathrm{~kb})$, os quais podem ser conjugativos, haja visto que as cepas em questão estavam distribuídas em diversos setores da instituição estudada (Figura 11). Além disso, a maioria destas cepas (exceto as produtoras de SHV-110) possuía plasmídios do grupo IncA/C, o qual foi o mais frequente entre as cepas clínicas neste estudo (Tabela 6).

\subsection{Genes bla ${ }_{\mathrm{CTX}-\mathrm{M}}$}

O presente estudo detectou genes do grupo $b l a_{\mathrm{CTX-M-2}}\left(b l a_{\mathrm{CTX}-\mathrm{M}-2}, b l a_{\mathrm{CTX}-\mathrm{M}-59}\right.$ e $\left.b l a_{\mathrm{CTX}-\mathrm{M}-131}\right)$ em cepas de diversas espécies isoladas de pacientes em diversas alas de um hospital, entre julho de 2004 e julho de 2005 (Tabela 1, Figura 14).

A família de $\beta$-lactamases CTX-M é composta por 5 grupos, CTX-M-1, CTX-M-2, CTX-M-8, CTX-M-9 e CTX-M-25, além de algumas enzimas isoladas. Apesar de terem sido descritas primeiramente na Europa, foi na América do Sul que se tornaram prevalentes, onde genes do grupo $b l a_{\mathrm{CTX}-\mathrm{M}-2}$ são os mais frequentes (ROSSOLINI et al. 2008; VILLEGAS et al. 2008; LIVERMORE 2012). Foram detectados na Argentina, em 1989 (BAUERNFEIND et al. 1992), e posteriormente disseminados para diversos países latinos, incluindo o Brasil, onde são considerados endêmicos. Este estudo é mais um relato do gene $b l a_{\mathrm{CTX}-\mathrm{M}-2}$ em cepas clínicas no Brasil, entre diversos publicados recentemente, mostrando que sua disseminação permanece ocorrendo em nossas instituições (VILLEGAS et al. 2008; FERNANDES 
et al. 2009; PEIRANO et al. 2009; PICÃO et al. 2009; CLÍMACO et al. 2010; LOPES et al. 2010; CHAGAS et al. 2011; TOLLENTINO et al. 2011; QUEIROZ et al. 2012; ZAVASCKI et al. 2012).

Além de bla $a_{\mathrm{CTX}-\mathrm{M}-2}$, o gene $b l a_{\mathrm{CTX}-\mathrm{M}-59}$ também foi detectado nas cepas clínicas deste trabalho, associado a $b l a_{\mathrm{SHV}-12}, b l a_{\mathrm{SHV}-27}$ e $b l a_{\mathrm{SHV}-110}$. CTX-M-59 possui a substituição $\mathrm{His}_{89} \rightarrow$ Leu em relação a CTX-M-2, e foi caracterizada em um estudo brasileiro, em meio a um surto de cepas de $K$. pneumoniae produtoras de CTX-M-2 (DE OLIVEIRA GARCIA et al. 2009). Sua disseminação no Brasil foi recentemente associada a plasmídios do grupo $\mathrm{IncA} / \mathrm{C}$, os quais foram detectados em

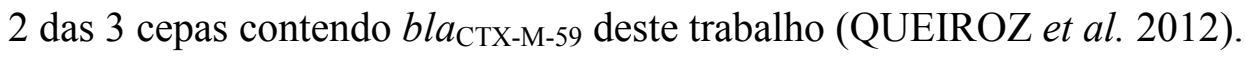

Este estudo também identificou o novo gene $b l a_{\text {CTX-M-131, que codifica uma }}$ ESBL com a substituição $\mathrm{Asp}_{239} \rightarrow$ Gly em relação à CTX-M-2, em um isolado de Providencia rettgeri (FSP309/05). Esta substituição é encontrada também na enzima CTX-M-43, porém na última há também a substituição $\operatorname{Ser}_{272} \rightarrow$ Arg, a qual não está presente na nova sequência de aminoácidos. A cepa possui altos valores de CIM para cefotaxima $(256 \mu \mathrm{g} / \mathrm{mL})$, cefepime $(64 \mu \mathrm{g} / \mathrm{mL})$ e amoxicilina/clavulanato $(128 \mu \mathrm{g} / \mathrm{mL})$, a última provavelmente devido à produção concomitante de AmpC $\beta$ lactamase cromossômica. A alta taxa de mobilidade dos genes bla CTX-M-2 $_{\text {entre os }}$ isolados de diversas espécies, bem como a pressão seletiva de antimicrobianos, são as causas mais prováveis do surgimento de um novo gene, devido a eventos de mutação. Apesar de não ter sido detectado nenhum grupo Inc por PBRT nesta cepa, a mesma possui plasmídios de $112 \mathrm{~kb}$ e $145,5 \mathrm{~kb}$. Se o gene $b l a_{\mathrm{CTX}-\mathrm{M}-131}$ estiver 
localizado em algum destes plasmídios, pode ter sido disseminado por transferência horizontal.

Os genes do grupo $b l a_{\text {CTX-M-2 }}$ deste estudo faziam parte de uma estrutura denominada integron de classe 1 complexo, um elemento que além de adquirir cassetes genéticos de resistência integrando os mesmos em sua região variável por meio de recombinação sítio-específica, se tornou móvel devido à presença da ISCR1, a qual pode mover grandes porções de DNA (TOLEMAN \& WALSH 2011; CANTÓN et al. 2012; STALDER et al. 2012).

A presença de genes do grupo bla $a_{\mathrm{CTX}-\mathrm{M}-2}$ em integrons de classe 1 complexos já foi relatada algumas vezes na América Latina, porém este é o primeiro relato no Brasil, mostrando a disseminação de uma estrutura de resistência altamente mobilizável em nosso país (POWER et al. 2005; VIGNOLI et al. 2006; QUIROGA et al. 2007).

$\mathrm{Na}$ época do isolamento das cepas produtoras de enzimas do grupo CTX-M-2 deste estudo, já havia sido observado que eram mais comuns em cepas de espécies variadas ou geneticamente distintas, sugerindo-se que poderia ter ocorrido um surto de genes $b l a_{\mathrm{CTX}-\mathrm{M}}$ na instituição (DROPA et al. 2009). Ainda que não se tenha determinado que os integrons de classe 1 complexos contendo bla $_{\mathrm{CTX}-\mathrm{M}-2}$, bla $_{\mathrm{CTX}-\mathrm{M}-59}$ ou $b l a_{\text {CTX-M-131 }}$ estivessem localizados em plasmídios, é possível que estes elementos tenham se mobilizado para os plasmídios de alto peso molecular presentes nessas cepas e que tenham sido transferidos por conjugação. As cepas de M. morganii e uma cepa de K. pneumoniae (FSP237/05) contendo essa estrutura não possuíam plasmídios de alto peso molecular e/ou tiveram resultados negativos para a técnica de 
PBRT, e como não eram clones podem ter recebido o elemento por conjugação por meio de um plasmídio mobilizável (baixo peso molecular) e grupo Inc não detectável por PBRT, ou ainda o elemento pode ter se integrado em seu DNA cromossômico.

Como se pode observar nas Figuras 11 e 14, genes do grupo CTX-M-2 foram menos frequentes em setores pediátricos do hospital, nos quais foram detectados mais genes do grupo SHV. Pode ter ocorrido, em alguns casos, que cepas contendo plasmídios do mesmo grupo de incompatibilidade (grupo IncA/C, por exemplo), localizadas em setores distintos, não tenham tido êxito na conjugação de seus plasmídios, por serem do mesmo grupo Inc.

A epidemiologia das enzimas CTX-M envolve tanto disseminação plasmidial como sucesso clonal. Um exemplo disso é a disseminação de CTX-M-15 de formas diferentes em K. pneumoniae e E. coli: em $K$. pneumoniae, o gene bla $a_{\mathrm{CTX}-\mathrm{M}-15}$ é geralmente transferido por plasmídios do grupo IncF para cepas geneticamente distintas, sem grande sucesso na disseminação clonal, enquanto que cepas da linhagem $\mathrm{ST}_{131}$ de $E$. coli contendo plasmídios IncF carreadores de bla $a_{\mathrm{CTX}-\mathrm{M}-15}$ estão distribuídas mundialmente. Não se sabe ao certo se uma $\mathrm{ST}_{131}$ progenitora adquiriu o plasmídio e se disseminou, ou se esta linhagem de células adquiriu repetidamente plasmídios IncF-CTX-M-15 (LIVERMORE 2012). Plasmídios IncF não são exclusivos do clone $\mathrm{ST}_{131}$, podendo estar presentes em outras linhagens de E. coli (CARATTOLI 2009).

Neste estudo, foram identificadas duas cepas produtoras de CTX-M-15, uma E. coli e uma K. pneumoniae, ambas isoladas da ETE 1. A cepa de K. pneumoniae FSP1271/09 era proveniente de uma amostra de esgoto tratado e possuía também 
SHV-28, identificada em 5 cepas clínicas deste estudo, e foi negativa para a técnica de PBRT. A cepa de E. coli FSP1314/09 foi isolada do esgoto bruto da mesma ETE, em coleta realizada dois meses depois, e possuía plasmídios IncFIA e IncFIB, variantes de IncF. Seriam necessários estudos adicionais para investigar a linhagem celular da cepa FSP1314/09.

Apesar de não ter sido detectada nas cepas clínicas deste estudo em particular, a enzima CTX-M-15 já foi relatada diversas vezes em amostras clínicas no Brasil (CERGOLE-NOVELLA et al. 2010; CHAGAS et al. 2011; PEIRANO et al. 2011; TOLLENTINO et al. 2011), porém não em cepas de amostras ambientais, apesar de estar disseminada mundialmente, em amostras clínicas humanas e animais, bem como no ambiente (CANTÓN et al. 2012; LIVERMORE 2012). Portanto, este é o primeiro relato da enzima CTX-M-15 em uma amostra ambiental no Brasil.

Em ambas as cepas, o ambiente genético de $b l_{\mathrm{CTX}-\mathrm{M}-15}$ envolvia o elemento ISEcp1, cuja sequência encontrava-se interrompida pela IS26. Assim como Tn3 e ISCR1, a ISEcp 1 se mobiliza por meio da transposição de extremidade única, e por estar frequentemente ligada ao gene $b l a_{\mathrm{CTX}-\mathrm{M}-15}$, já está disseminada mundialmente apesar de ter sido descrita há pouco mais de 10 anos (TOLEMAN \& WALSH 2011; CANTÓN et al. 2012). Apesar disso, nas cepas deste estudo o fato de estar truncada pela IS26 provavelmente impede a transposição da ISEcp1 e confina sua localização para genótipos específicos, e a mobilização do gene $b l_{\mathrm{CTX}-\mathrm{M}-15}$ fica a cargo da IS26, a qual apesar de não realizar transposição de extremidade única possui normalmente muitas cópias ao longo do DNA e por isso se transpõe com facilidade (TOLEMAN \& WALSH 2011; SHAHID et al. 2012). O recente estudo de DIMUDE \& AMYES 
(2012) também descreve esta estrutura (ISEcp1-IS26-ISEcp1) em algumas cepas produtoras de CTX-M-15, entre outras onde a ISEcp1 não estava interrompida.

Este estudo relata, portanto, a detecção do gene $b l a_{\mathrm{CTX}-\mathrm{M}-15}$ associado a um elemento genético que possui facilidade de mobilização. Este é um achado importante e preocupante em termos de disseminação da resistência, uma vez que independente de como esse gene tenha chegado ou surgido nas amostras de esgoto (inclusive tratado) da ETE 1, o mesmo pode a partir deste local ser disseminado para outras matrizes ambientais, como água e solo, podendo então atingir os alimentos, os animais ou o homem (Figura 1), representando portanto um risco à saúde da população.

O gene $b l a_{\mathrm{CTX}-\mathrm{M}-8}$ foi detectado em 5 cepas provenientes de ETEs diferentes da Grande São Paulo, em amostras de esgoto bruto, esgoto tratado e lodo de esgoto. Este gene foi descrito no Brasil em 2000, e deu origem a um novo cluster de genes bla $a_{\mathrm{CTX}-\mathrm{M}}(\mathrm{BONNET}$ et al. 2000). Após sua caracterização, novos relatos de CTX-M8 só foram publicados a partir de 2007, tanto na América Latina como nos Estados Unidos, Europa e África, em amostras clínicas e de alimentos (LEWIS et al. 2007; JOUINI et al. 2007; MINARINI et al. 2009; PEIRANO et al. 2009; VINUÉ et al. 2009; GARCÍA-FULGUEIRAS et al. 2011; KIIRU et al. 2012; MAHROUKI et al. 2012; SENNATI et al. 2012). Portanto, este é o primeiro relato da enzima CTX-M-8 em amostras de esgoto e/ou derivados, sugerindo que cepas de origem clínica e seus genes de resistência estão atingindo as estações de tratamento de esgoto, podendo então se disseminar na natureza após o lançamento do esgoto tratado no ambiente. $\mathrm{O}$ fato de genes do grupo bla $_{\mathrm{CTX}-\mathrm{M}-2}$ não terem sido identificados nessas amostras de 
esgoto pode ter ocorrido devido a alguma mudança na epidemiologia das enzimas CTX-M em nossa região, como está ocorrendo na Argentina, onde a ESBL CTX-M2 permanece endêmica e as enzimas CTX-M-15 e CTX-M-8 estão emergindo (SENNATI et al. 2012). Outro motivo pode ter sido o fato dos genes terem sido pesquisados em cepas cultivadas, o que limita muito a detecção dos genes de resistência (STALDER et al. 2012).

O gene $b l a_{\text {CTX-M-8 }}$ das cepas deste estudo está associado à IS26, que como já foi mencionado, possui muitas cópias no genoma e por isso encontra com facilidade outra IS26 para realizar a mobilização de toda a estrutura que estiver entre elas. Por outro lado, o gene $b l a_{\text {CTX-M-8 }}$ estava diretamente ligado a outra sequência de inserção, IS 10, que ao contrário da IS26 é estritamente regulada e possui baixa frequência de transposição (EICHENBAUM \& LIVNEH 1998; HARADA et al. 2010; STOEBEL \& DORMAN 2010; TOLEMAN \& WALSH 2011). No caso das cepas deste estudo, a IS10 encontrava-se interrompida pela IS26, o que provavelmente impede a transcrição da sua transposase. Seria necessário mapear regiões maiores das duas extremidades que compõem o ambiente genético de bla $a_{\mathrm{CTX}-\mathrm{M}-8}$ para afirmar a provável forma de mobilização do mesmo. Apesar disso, o fato de estar associado à IS26, cuja frequência de transposição é naturalmente alta, pode sugerir que em algum momento possa ter havido a mobilização do gene $b l_{\mathrm{CTX}-\mathrm{M}-8}$ por meio da IS26 ou de uma estrutura maior para um plasmídio, o qual iniciou sua disseminação.

As três cepas de $E$. coli que continham bla $a_{\mathrm{CTX}-\mathrm{M}-8}$ possuíam também plasmídios do grupo IncI1, enquanto as cepas de $K$. pneumoniae e E. cloacae possuíam plasmídios IncL/M. Ambos os grupos Inc estão entre os principais 
disseminadores de resistência entre enterobactérias no mundo (CARATTOLI 2009). As cinco cepas continham plasmídios de alto peso molecular de tamanhos diferentes, e não foi possível associá-los a um grupo Inc específico, ou à disseminação do gene

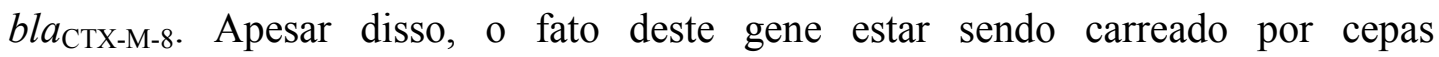
geneticamente distintas, isoladas de amostras diferentes de estações de tratamento de esgoto diferentes, sugere que a disseminação de CTX-M-8 esteja ocorrendo por meio de transferência genética horizontal.

A dispersão da família CTX-M de $\beta$-lactamases no mundo todo é considerada uma pandemia, devido ao crescente número de relatos e à disseminação de seus genes em estruturas genéticas altamente mobilizáveis, bem como a presença dessas estruturas em clones bem sucedidos (CANTÓN et al. 2012). Este estudo destaca a permanência e disseminação dos genes do grupo $b l a_{\text {CTX-M-2 }}$ em uma instituição hospitalar durante 1 ano entre 2004 e 2005, devido provavelmente à sua presença em integrons de classe 1 complexos, além de relatar pela primeira vez no Brasil a presença dos genes $b l a_{\mathrm{CTX}-\mathrm{M}-15}$ e $b l a_{\mathrm{CTX}-\mathrm{M}-8}$ em amostras ambientais, coletadas de estações de tratamento de esgoto da Grande São Paulo em 2009.

Não foi possível detectar os grupos Inc de 12 cepas clínicas e uma cepa ambiental. Isto pode ter ocorrido devido às limitações da técnica de PBRT, a qual foi padronizada para os 18 replicons que representam os grupos de incompatibilidade principais das espécies de Enterobacteriaceae, deixando portanto de detectar grupos mais raros ou ainda não caracterizados (CARATTOLI et al. 2005). 


\subsection{Considerações Finais}

Os resultados deste estudo trazem a identificação de genes codificadores de ESBL presentes tanto em cepas clínicas isoladas em um hospital público em 2004/2005, como em cepas isoladas do esgoto de cinco ETEs da Grande São Paulo em 2009. Além disso, os resultados aqui apresentados mostram a variedade de elementos genéticos mobilizáveis relacionados aos genes $b l a_{\mathrm{ESBL}}$ identificados em ambas as fontes.

Em relação às cepas clínicas, o estudo mostra a importância da consciência de que a disseminação da resistência antimicrobiana no ambiente de uma instituição independe muitas vezes de uma disseminação clonal. Além disso, os genes de resistência podem se disseminar da instituição para a comunidade em geral e para a natureza por diversos veículos - profissionais de saúde, visitantes da instituição, esgoto hospitalar, ou do próprio paciente após a alta hospitalar - representando portanto um importante risco à saúde humana.

Os elementos de mobilização genética associados aos genes bla $a_{\mathrm{ESBL}}$ identificados nas cepas deste estudo sugerem que possa haver a disseminação dessas estruturas da clínica para o ambiente e vice-versa. A presença de uma maioria de cepas contendo plasmídios de alto peso molecular e grupos Inc associados, segundo a literatura, à disseminação da resistência a antimicrobianos, também aponta para a alta capacidade de mobilização de genes $b l a_{\mathrm{ESBL}}$ por transferência horizontal entre enterobactérias. 
Este estudo relata também a presença de três genes de resistência pela primeira vez no Brasil, além da descrição de dois genes bla $a_{\mathrm{ESBL}}$ novos, em cepas isoladas no ambiente hospitalar. Estes resultados podem demonstrar tanto a possibilidade de disseminação dos genes devido à globalização e portanto ao trânsito de pessoas entre os países, como a possibilidade do surgimento de novos genes devido a mutações favorecidas provavelmente pela pressão seletiva do uso de antimicrobianos nos serviços de assistência à saúde.

Os resultados deste estudo alertam para a disseminação da resistência a $\beta$ lactâmicos, além do ambiente hospitalar, nas ETEs da Grande São Paulo por genes codificadores de ESBL em bactérias da família Enterobacteriaceae. As amostras ambientais deste estudo representam apenas uma pequena parte dos produtos (esgoto tratado, lodo de esgoto) provenientes das estações de tratamento de esgoto da Grande São Paulo, porém os resultados podem servir de alerta para o lançamento e aplicação adequados e conscientes destes produtos, além de sinalizar para a necessidade da investigação da presença de bactérias resistentes no esgoto que será lançado no ambiente.

A resistência a antimicrobianos é um grave problema de Saúde Pública que atualmente envolve diversas áreas do conhecimento, uma vez que há disseminação de genes codificadores de resistência em amostras clínicas, ambientais e de alimentos. Essa preocupação vai além da presença de cepas resistentes no ambiente clínico ou na natureza, e depende de profissionais de diversos setores a proposta de soluções para a prevenção e o controle do problema. 
A dispersão de bactérias resistentes no ambiente favorece a interação das mesmas com a microbiota local, criando novas possibilidades de evolução da resistência a antimicrobianos. Além disso, o contato de bactérias com resíduos químicos (metais pesados, antimicrobianos) lançados na natureza pelas indústrias também pode favorecer o surgimento de células resistentes. O uso da profilaxia com antimicrobianos, de adubação orgânica ou de lodo de esgoto na agricultura podem levar à contaminação dos alimentos tanto por antimicrobianos como bactérias resistentes. E finalmente, o uso profilático ou como estimuladores de crescimento dos antimicrobianos nas criações de animais leva à colonização do trato gastrintestinal dos mesmos por bactérias resistentes, ou ainda à contaminação da carne com antimicrobianos, podendo em ambos casos oferecer risco à saúde humana. Todos os fatores acima podem favorecer tanto o surgimento de novos genes de resistência como a disseminação dos mesmos para diversos ambientes, como ilustrado na Figura 1.

O desenvolvimento de novas drogas e propostas de eliminação de plasmídios do ambiente têm sido avaliados (CARATTOLI 2009; LIVERMORE 2012), mas há ainda uma longa distância até o controle da disseminação da resistência. O controle da venda de antimicrobianos no Brasil, bem como o estabelecimento de limites para o uso dos mesmos na agricultura e criações de animais, mostram que existe a preocupação das autoridades com a questão da resistência, porém outras medidas e planos de controle do uso dessas drogas ainda necessitam ser elaborados, como protocolos que visem a investigação da resistência e da presença de antimicrobianos nos alimentos e no esgoto lançado na natureza. 
Sendo assim, a conscientização do uso racional de antimicrobianos na clínica, agricultura e pecuária, e o lançamento adequado do esgoto hospitalar, industrial e doméstico, ainda parecem ser o caminho mais razoável a ser seguido para prevenir a disseminação da resistência bacteriana. 


\section{CONCLUSÕES}

- Foram detectados 13 genes bla $a_{\mathrm{ESBL}}$ diferentes nas amostras clínicas e 3 nas ambientais, sendo um deles comum aos dois tipos de amostra;

- Três genes ainda não haviam sido relatados no Brasil, e dois genes codificavam novas enzimas $\beta$-lactamases;

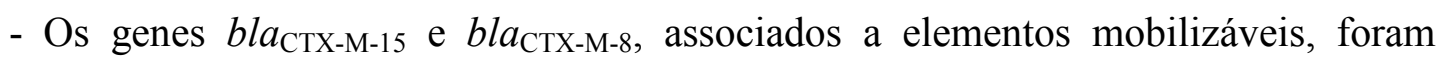
detectados pela primeira vez em amostras ambientais no Brasil;

- Integrons de classe 1 complexos associados a genes do grupo bla $a_{\mathrm{CTX}-\mathrm{M}-2}$ foram identificados pela primeira vez no Brasil;

- Plasmídios pertencentes a grupos de incompatibilidade envolvidos na disseminação de genes de resistência no mundo todo foram os mais frequentes neste estudo;

- A maioria das cepas deste estudo abrigavam plasmídios de alto peso molecular, possivelmente conjugativos;

- Genes bla $a_{\mathrm{ESBL}}$ comumente encontrados em amostras clínicas foram detectados no esgoto, alertando para a possibilidade de atingirem outros corpos d'água ou o solo após seu lançamento e/ou reúso. 


\section{REFERÊNCIAS BIBLIOGRÁFICAS}

1. Agência Nacional de Vigilância Sanitária (ANVISA). Portaria $N^{0} 2.616$, de 12 de maio de 1998. Define as Diretrizes e Normas para a Prevenção e o Controle das Infecções Hospitalares [lei na Internet]. [acesso em 28 Jan 2012]. Disponível em: http://www.anvisa.gov.br/.

2. Agência Nacional de Vigilância Sanitária (ANVISA). Resolução RDC No 44, de 28 de outubro de 2010. Dispõe sobre o controle de medicamentos à base de substâncias classificadas como antimicrobianos, de uso sob prescrição médica, isoladas ou em associação e dá outras providências [lei na Internet]. [acesso em 29 Jan 2013]. Disponível em http://www.anvisa.gov.br.

3. American Society for Microbiology (ASM). Antibiotic Resistance: an ecological perspective on an old problem. Washington (DC): American Academy of Microbiology (US); 2009 Sep. 32p.

4. Ansari MI, Malik A. Genotoxicity of agricultural soils in the vicinity of industrial area. Mutat Res. 2009; 673:124-132.

5. Arpin C, Dubois V, Coulange L, André C, Fischer I, Noury P, Grobost F, Brochet JP, Jullin J, Dutilh B, Larribet G, Lagrange I, Quentin C. Extendedspectrum beta-lactamase-producing Enterobacteriaceae in community and private health care centers. Antimicrob Agents Chemother. 2003;47(11):3506-3514.

6. Arpin C, Dubois V, Maugein J, Jullin J, Dutilh B, Brochet JP, Larribet G, Fischer I, Quentin C. Clinical and molecular analysis of extended-spectrum $\beta$-lactamaseproducing Enterobacteria in the community setting. J Clin Microbiol. 2005;43(10):5048-5054.

7. Arthur A, Nimmo E, Hettle S, Sherratt D. Transposition and transposition immunity of transposon Tn3 derivatives having different ends. EMBO J. 1984;3(8):1723-1729.

8. Babini GS, Livermore DM. Are SHV $\beta$-lactamases Universal in Klebsiella pneumoniae?. Antimicrob Agents Chemother. 2000; 44: 2230.

9. Bae IK, Lee YH, Jeong HJ, Hong SG, Lee SH, Jeong SH. A novel bla $a_{\mathrm{CTX}-\mathrm{M}-14}$ gene-harboring complex class 1 integron with an In4-like backbone structure from a clinical isolate of Escherichia coli. Diagn Microbiol Infect Dis. 2008;62(3):340-342.

10. Baquero F, Martínez JL, Cantón R. Antibiotics and antibiotic resistance in water environments. Curr Opin Biotechnol. 2008; 19:260-265.

11. Barguigua A, El Otmani F, Talmi M, Reguig A, Jamali L, Zerouali K, Timinouni M. Prevalence and genotypic analysis of plasmid-mediated $\beta$-lactamases among 
urinary Klebsiella pneumoniae isolates in Moroccan community. The Journal of Antibiotics. 2012; Epub ahead of print.

12. Barlow M, Reik RA, Jacobs SD, Medina M, Meyer MP, McGowan JE, Tenover

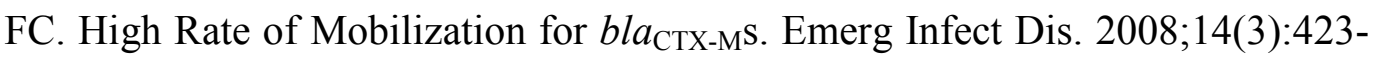
428.

13. Bartón BM, Harding GP, Zuccarelli AJ. A general method for detecting and sizing large plasmids. Genimics 1995; 29(3):690-697.

14. Bauernfeind A, Casellas JM, Goldberg M, Holley M, Jungwirth R, Mangold P, Röhnisch T, Schweighart S, Wilhelm R. A new plasmidic cefotaximase from patients infected with Salmonella typhimurium. Infection. 1992;20(3):158-163.

15. Billot-Klein D, Gutmann L, Collatz E. Nucleotide sequence of the SHV-5 betalactamase gene of a Klebsiella pneumoniae plasmid. Antimicrob Agents Chemother. 1990;34(12):2439-2441.

16. Bonnet R, Sampaio JL, Labia R, De Champs C, Sirot D, Chanal C, Sirot J. A novel CTX-M beta-lactamase (CTX-M-8) in cefotaxime-resistant Enterobacteriaceae isolated in Brazil. Antimicrob Agents Chemother. 2000;44(7):1936-1942.

17. Bonnet R, Dutour C, Sampaio JL, Chanal C, Sirot D, Labia R, De Champs C, Sirot J. Novel cefotaximase (CTX-M-16) with increased catalytic efficiency due to substitution Asp-240-->Gly. Antimicrob Agents Chemother. 2001;45(8):22692275 .

18. Bradford PA. Extended-spectrum $\beta$-lactamases in the $21^{\text {st }}$ century: characterization, epidemiology, and detection of this important resistance threat. Clin Microbiol Rev. 2001; 14:933-951.

19. Brown KD, Kulis J, Thomson B, Chapman TH, Mawhinney DB. Occurrence of antibiotics in hospital, residential, and dairy effluent, municipal wastewater, and the Rio Grande in New Mexico. Sci Total Environ. 2006; 366:772-783.

20. Bush K, Jacoby GA. Amino Acid Sequences for TEM, SHV and OXA Extendedspectrum and Inhibitor Resistant $\beta$-lactamases. Lahey Clinic [homepage na internet] c2003. [acesso em 28 Jan 2013]. Disponível em: http://www.lahey.org/studies.

21. Bush K, Jacoby GA. An updated functional classification of $\beta$-lactamases. Antimicrob Agents Chemother. 2010 Mar;54(3):969-976.

22. Caccamo M, Perilli M, Celenza G, Bonfiglio G, Tempera G, Amicosante G. Occurrence of extended spectrum beta-lactamases among isolates of Enterobacteriaceae from urinary tract infections in southern Italy. Microb Drug Resist. 2006;12(4):257-264. 
23. Cantón R, Coque TM. The CTX-M $\beta$-lactamase pandemic. Curr Opin Microbiol. 2006; 9:466-475.

24. Cantón R, González-Alba JM, Galán JC. CTX-M enzymes: origin and diffusion. Front Microbiol. 2012;3:110.

25. Carattoli A. Animal reservoirs for extended-spectrum $\beta$-lactamase producers. Clin Microbiol Infect. 2008; 14(s1):117-123.

26. Carattoli A. Resistance Plasmid Families in Enterobacteriaceae. Antimicrob Agents Chemother. 2009; 53(6):2227-2238.

27. Carattoli A, Bertini A, Villa L, Falbo V, Hopkins KL, Threlfall EJ. Identification of plasmids by PCR-based replicon typing. JM icrobiol Methods. 2005; 63: 219228.

28. Casellas JM, Goldberg M. Incidence of strains producing extended spectrum beta-lactamases in Argentina. Infection. 1989; 17:434-436.

29. Cergole-Novella MC, Guth BE, Castanheira M, Carmo MS, Pignatari AC. First description of bla $a_{\mathrm{CTX}-\mathrm{M}-14^{-}}$and bla $a_{\mathrm{CTX}-\mathrm{M}-15-p r o d u c i n g}$ Escherichia coli isolates in Brazil. Microb Drug Resist. 2010;16(3):177-184.

30. Chagas TP, Alves RM, Vallim DC, Seki LM, Campos LC, Asensi MD. Diversity of genotypes in CTX-M-producing Klebsiella pneumoniae isolated in different hospitals in Brazil. Braz J Infect Dis. 2011; 15(5):420-425.

31. Chapman PA, Ellin M, Ashton R, Shafique W. Comparison of culture, PCR and immunoassays for detecting Escherichia coli O157 following enrichment culture and immunomagnetic separation performed on naturally contaminated raw meat products. Int J Food Microbiol. 2001;68:11-20.

32. Chaves J, Ladona MG, Segura C, Coira A, Reig R, Ampurdanés C. SHV-1 betalactamase is mainly a chromosomally encoded species-specific enzyme in Klebsiella pneumoniae. Antimicrob Agents Chemoter. 2001;45(10):2856-2861.

33. Chouchani C, Ben-Achour N, M'Charek A, Belhadj O. Cloning and sequencing of the class A beta-lactamase gene (bla ${ }_{\text {TEM-15 }}$ ) located on a chromosomal Tn 801 transposon. Diagn Microbiol Infect Dis. 2007;58(4):459-463.

34. Clímaco EC, Minarini LA, da Costa Darini AL. CTX-M-producing Klebsiella spp. in a Brazilian hospital: what has changed in 6 years? Diagn Microbiol Infect Dis. 2010;68(2):186-189.

35. Clinical and Laboratory Standards Institute (CLSI). Performance Standards for Antimicrobial Susceptibility Testing; Twenty-Second Informational Supplement. CLSI Publication M100-S22, Vol. 32, No. 3. Wayne, PA: CLSI; 2012. 
36. Corkill JE, Cuevas LE, Gurgel RQ Greensill J, Hart CA. SHV-27, a novel cefotaxime hydrolyzing $\beta$-lactamase, identified in Klebsiella pneumoniae isolates from a Brazilian hospital. J Antimicrob Chemother. 2001;47:463-465.

37. De Boeck H, Lunguya O, Muyembe JJ, Glupczynski Y, Jacobs J. Presence of extended-spectrum beta-lactamase-producing Enterobacteriaceae in waste waters, Kinshasa, the Democratic Republic of the Congo. Eur J Clin Microbiol Infect Dis. 2012;31(11):3085-3088.

38. De Oliveira Garcia D, Doi Y, Szabo D, Adams-Haduch JM, Vaz TM, Leite D, Padoveze MC, Freire MP, Silveira FP, Paterson DL. Multiclonal outbreak of Klebsiella pneumoniae producing extended-spectrum beta-lactamase CTX-M-2 and novel variant CTX-M-59 in a neonatal intensive care unit in Brazil. Antimicrob Agents Chemother. 2008;52(5):1790-1793.

39. Dimude JU, Amyes SG. Molecular diversity associated with the dissemination of CTX-M-15 beta-lactamase gene in blood culture isolates of Escherichia coli from Edinburgh. Scand J Infect Dis. 2012; Epub ahead of print.

40. Diwan V, Chandran SP, Tamhankar AJ, Lundborg CS, Macaden R. Identification of extended-spectrum $\beta$-lactamase and quinolone resistance genes in Escherichia coli isolated from hospital wastewater from central India. J Antimicrob Chemother. 2012;67:857-859.

41. Dropa M. Caracterização genotípica de cepas da família Enterobacteriaceae produtoras de $\beta$-lactamases de espectro estendido, isoladas de pacientes de um hospital da rede pública da cidade de São Paulo [dissertação de mestrado]. São Paulo: Faculdade de Saúde Pública da USP; 2006.

42. Dropa M, Balsalobre LC, Lincopan N Mamizuka EM, Murakami T, Cassettari VC, Franco F, Guida SM, Balabakis AJ, Passadore LF, Santos SR, Matté GR, Matté MH. Extended-spectrum beta-lactamases among Enterobacteriaceae isolated in a public hospital in Brazil. Rev Inst Med Trop São Paulo. 2009;51(4):203-209.

43. Eichenbaum Z, Livneh Z. UV light induces IS10 transposition in Escherichia coli. Genetics. 1998;149(3):1173-1181.

44. El Far F, Marino CGJ, Medeiros EAS. The organization of hospital infection control committees and their importance in Brazil. Braz J Infect Dis. 2001; 5(6):290-293.

45. Fernandes SA, Paterson DL, Ghilardi-Rodrigues AC, Adams-Haduch JM, Tavechio AT, Doi Y. CTX-M-2-producing Salmonella Typhimurium isolated from pediatric patients and poultry in Brazil. Microb Drug Resist. 2009;15(4):317-321. 
46. Fevre C, Passet V, Weill FX, Grimont PA, Brisse S. Variants of the Klebsiella pneumoniae chromosomal OKP beta-lactamase are divided into two main groups, OKP-A and OLP-B. Antimicrob Agents Chemother. 2005;49(12):51495152.

47. Fluit AC, Schmitz FJ. Resistance integrons and super-integrons. Clin Microb Infect. 2004;10(4):272-288.

48. Francia MV, Varsaki A, Garcillán-Barcia MP, Latorre A, Drainas C, De la Cruz F. A classification scheme for mobilization regions of bacterial plasmids. FEMS Microb Rev. 2004;28:79-100.

49. Frost L, Ippen-Ihler K, Skurray RA. Analysis of the sequence and gene products of the transfer region of the F sex factor. Microbiol Rev. 1994;58(2):162-210.

50. Garcillán-Barcia MP, Francia MV, De la Cruz F. The diversity of conjugative relaxases and its application in plasmid classification. FEMS Microb Rev. 2009;33:657-687.

51. Gales AC, Castanheira M, Jones RN, Sader HS. Antimicrobial resistance among Gram-negative bacilli isolated from Latin America: results from SENTRY Antimicrobial Surveillance Program (Latin America, 2008-2010). Diagn Microbiol Infect Dis. 2012;73(4):354-360.

52. Garcia-Alvarez L, Dawson S, Cookson B, Hawkey P. Working across the veterinary and human health sectors. J Antimicrob Chemother. 2012; 67(1):i37i49.

53. García-Fulgueiras V, Bado I, Mota MI, Robino L, Cordeiro NF, Varela A, Algorta G, Gutkind G, Ayala JA, Vignoli R. Extended-spectrum $\beta$-lactamases and plasmid-mediated quinolone resistance in enterobacterial clinical isolates in the paediatric hospital of Uruguay. J Antimicrob Chemother. 2011;66(8):17251729.

54. Gniadkowski M. Evolution of extended-spectrum $\beta$-lactamases by mutation. Clin Microbiol Infect. 2008; 14(s1):11-32.

55. Gutmann L, Ferré B, Goldstein FW, Rizk N, Pinto-Schuster E, Acar JF, Collatz E. SHV-5, a novel SHV-type beta-lactamase that hydrolyzes broad-spectrum cephalosporins and monobactams. Antimicrob Agents Chemother. 1989; 33:951-956.

56. Hammad AM, Ishida Y, Shimamoto T. Prevalence and molecular characterization of ampicillin-resistant Enterobacteriaceae isolated from traditional Egyptian Domiati cheese. J Food Prot. 2009;72(3):624-630. 
57. Hammad AM, Shimamoto T. Asymptomatic intramammary infection with multidrug-resistant gram-negative bacteria in a research dairy farm: incidence and genetic basis of resistance. J Vet Med Sci. 2011;73(8):1089-1092.

58. Hammond DS, Harris T, Bell J, Turnidge J, Giffard PM. Selection of SHV extended-spectrum-beta-lactamase-dependent cefotaxime and ceftazidime resistance in Klebsiella pneumoniae requires a plasmid-borne bla $a_{\mathrm{SHV}}$ gene. Antimicrob Agents Chemother. 2008;52(2):441-445.

59. Harada S, Ishii Y, Saga T, Tateda K, Yamaguchi K. Chromosomally Encoded bla $a_{\mathrm{CMY}-2}$ Located on a Novel SXT/R391-Related Integrating Conjugative Element in a Proteus mirabilis Clinical Isolate. Antimicrob Agents Chemother. 2010;54(9):3545-3550.

60. Hartmann A, Locatelli A, Amoureux L, Depret G, Jolivet C, Gueneau E, Neuwirth C. Occurrence of CTX-M Producing Escherichia coli in Soils, Cattle, and Farm Environment in France (Burgundy Region). Front Microbiol. 2012;3:83.

61. Hawkey PM, Jones AM. The changing epidemiology of resistance. J Antimicrob Therapy. 2009; 64(S1):i3-i10.

62. Howard C, van Daal A, Kelly G, Schooneveldt J, Nimmo G, Giffard PM. Identification and minisequencing-based discrimination of SHV beta-lactamases in nosocomial infection-associated Klebsiella pneumoniae in Brisbane, Australia. Antimicrob Agents Chemother. 2002;46(3):659-664.

63. Jemima SA, Verghese S. SHV-28, an extended-spectrum beta-lactamase produced by a clinical isolate of Klebsiella pneumoniae in south India. Indian J Med Microbiol. 2009;27(1):51-54.

64. Jiang HX, Tang D, Liu YH, Zhang XH, Zeng ZL, Xu L, Hawkey PM. Prevalence and characteristics of $\beta$-lactamase and plasmid-mediated quinolone resistance genes in Escherichia coli isolated from farmed fish in China. J Antimicrob Chemother. 2012;67(10):2350-2353.

65. Jouini A, Vinué L, Slama KB, Sáenz Y, Klibi N, Hammami S, Boudabous A, Torres C. Characterization of CTX-M and SHV extended-spectrum betalactamases and associated resistance genes in Escherichia coli strains of food samples in Tunisia. J Antimicrob Chemother. 2007;60(5):1137-1141.

66. Kim S, Kim J, Kang Y, Park Y, Lee B. Occurrence of extended-spectrum betalactamases in members of the genus Shigella in the Republic of Korea. J Clin Microbiol. 2004 Nov;42(11):5264-5269.

67. Kiratisin P, Apisarnthanarak A, Laesripa C, Saifon P. Molecular characterization and epidemiology of extended-spectrum-beta-lactamase-producing Escherichia coli and Klebsiella pneumoniae isolates causing health care-associated infection 
in Thailand, where the CTX-M family is endemic. Antimicrob Agents Chemother. 2008;52(8):2818-2824.

68. Kiiru J, Kariuki S, Goddeeris BM, Butaye P. Analysis of $\beta$-lactamase phenotypes and carriage of selected $\beta$-lactamase genes among Escherichia coli strains obtained from Kenyan patients during an 18-year period. BMC Microbiol. 2012;12:155.

69. Kliebe C, Nies BA, Meyer JF, Tolxdorff-Neutzling RM, Wiedemann B. Evolution of plasmid-coded resistance to broad-spectrum cephalosporins. Antimicrob Agents Chemother. 1985;28:302-307.

70. Knothe H; Shah P, Krcmery V, Antal M, Mitsuhashi S. Transferable resistance to cefotaxime, cefoxitin, cefamandole and cefuroxime in clinical isolates of Klebsiella pneumoniae and Serratia marcescens. 1983;11(6):315-317.

71. Lachmayr KL, Kerkhof LJ, DiRienzo G, Cavanaugh CM, Ford TE. Quantifying nonspecific TEM $\beta$-lactamase (bla TEM $_{\text {}}$ ) genes in a wastewater stream. Appl Environ Microbiol. 2009;75(1):203-211.

72. Lee $\mathrm{CH}$, Bhagwat $\mathrm{A}$, Heffron $\mathrm{F}$. Identification of a transposon Tn 3 sequence required for transposition immunity. Proc Natl Acad Sci USA. 1983;80(22):6765-6769.

73. Lewis JS 2nd, Herrera M, Wickes B, Patterson JE, Jorgensen JH. First report of the emergence of CTX-M-type extended-spectrum beta-lactamases (ESBLs) as the predominant ESBL isolated in a U.S. health care system. Antimicrob Agents Chemother. 2007;51(11):4015-4021.

74. Lin TL, Tang SI, Fang CT, Hsueh PR, Chang SC, Wang JT. Extended-spectrum beta-lactamase genes of Klebsiella pneumoniae strains in Taiwan: recharacterization of $s h v-27, s h v-41$, and tem-116. Microb Drug Resist. 2006;12(1):12-15.

75. Livermore D. Defining an extended-spectrum $\beta$-lactamase. Clin Microbiol Infect. 2008;14(s1):3-10.

76. Livermore DM. Current Epidemiology and Growing Resistance of GramNegative Pathogens. Korean J Intern Med. 2012;27:128-142.

77. Lopes AC, Veras DL, Lima AM, Melo Rde C, Ayala J. bla $a_{\mathrm{CTX}-\mathrm{M}-2}$ and bla ${ }_{\mathrm{CTX}-\mathrm{M}-}$ 28 extended-spectrum beta-lactamase genes and class 1 integrons in clinical isolates of Klebsiella pneumoniae from Brazil. Mem Inst Oswaldo Cruz. 2010;105(2):163-167.

78. Lord Soulsby of Swaffham Prior. The 2008 Garrod Lecture: Antimicrobial resistance - animals and the environment. J Antimicrob Chemother. 2008;62(2):229-233. 
79. Mahrouki S, Belhadj O, Chihi H, Mohamed BM, Celenza G, Amicosante G,

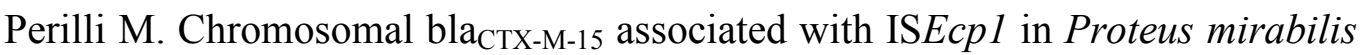
and Morganella morganii isolated at the Military Hospital of Tunis, Tunisia. J Med Microbiol. 2012;61(Pt9):1286-1289.

80. Mazel D. Integrons: agents of bacterial evolution. Nat Rev Microbiol. 2006;4(8):608-620.

81. Mendes C, Kiffer C, Segura A, Ribeiro J, Turner P. Klebsiella pneumoniae with multiple antimicrobial resistance. Braz J Infect Dis. 2004; 8(1):109-111.

82. Mendonça N, Ferreira E, Louro D; ARSIP Participants, Caniça M. Molecular epidemiology and antimicrobial susceptibility of extended- and broad-spectrum beta-lactamase-producing Klebsiella pneumoniae isolated in Portugal. Int J Antimicrob Agents. 2009;34(1):29-37.

83. Mendonça N, Manageiro V, Bonnet R, Caniça M. Biochemical characterization of SHV-55, an extended-spectrum class A beta-lactamase from Klebsiella pneumoniae. Antimicrob Agents Chemother. 2008;52(5):1897-1898.

84. Minarini LAR, Camargo ILBC, Pitondo-Silva A, Darini ALC. Multilocus sequence typing of uropathogenic ESBL-producing Escherichia coli isolated in a Brazilian community. Curr Microbiol. 2007;55(6):524-529.

85. Minarini LAR, Poirel L, Trevisani NAC, Darini ALC, Nordmann P. Predominance of CTX-M-type extended-spectrum $\beta$-lactamase genes among enterobacterial isolates from outpatients in Brazil. Diagn Microbiol Infect Dis. 2009;65:202-206.

86. Ministério da Agricultura, Pecuária e Abastecimento (MAPA). Instrução Normativa $\mathrm{N}^{\mathrm{o}}$ 11, de 22 de maio de 2012. Publica o Subprograma de Monitoramento em Carnes (Bovina, Aves, Suína e Equina), Leite, Pescado, Mel, Ovos e Avestruz para o exercício de 2012, referente ao Plano Nacional de Controle de Resíduos Biológicos em Produtos de Origem Animal [lei na Internet]. [acesso em 30 Jan 2013]. Disponível em: http://www.agricultura.gov.br.

87. Moura A, Henriques I, Smalla K, Correia A. Wastewater bacterial communities bring together broad-host range plasmids, integrons and a wide diversity of uncharacterized gene cassettes. Res Microbiol. 2010;161(1):58-66.

88. Mshana SE, Imirzalioglu C, Hossain H, Hain T, Domann E, Chakraborty T. Conjugative IncF1 plasmids carrying CTX-M-15 among Escherichia coli ESBL producing isolates at a University hospital in Germany. BMC Infect Dis. 2009; 9:97. 
89. Mullany P. Introduction to the multi-author review on conjugative transposons. Cell Mol Life Sci. 2002; 59(12):2017-2022.

90. Mulvey MR, Boyd DA, Baker L, Mykytczuk O, Reis EM, Asensi MD, Rodrigues DP, Ng LK. Characterization of a Salmonella enterica serovar Agona strain harbouring a class 1 integron containing novel OXA-type beta-lactamase (OXA-53) and 6'-N-aminoglycoside acetyltransferase genes [aac(6')-I30]. J Antimicrob Chemother. 2004;54(2):354-359.

91. Novais A, Baquero F, Machado E, Cantón R, Peixe L, Coque TM. International spread and persistence of TEM-24 is caused by the confluence of highly penetrating Enterobacteriaceae clones and an $\mathrm{IncA} / \mathrm{C} 2$ plasmid containing Tn1696::Tn1 and IS5075-Tn21. Antimicrob Agents Chemother. 2010;54(2):825-834.

92. Nüesch-Inderbinen MT, Kayser FH, Hächler H. Survey and molecular genetics of SHV beta-lactamases in Enterobacteriaceae in Switzerland: two novel enzymes, SHV-11 and SHV-12. Antimicrob Agents Chemother. 1997;41(5):943-949.

93. Organização Mundial da Saúde (OMS). A Crescente Ameaça da Resistência Antimicrobiana - Opções de Ação. [homepage na internet] c2013. [acesso em 29 Jan 2013]. Disponível em: http://www.who.int.

94. Pan JC, Ye R, Meng DM, Zhang W, Wang HQ, Liu KZ. Molecular characteristicis of class 1 and class 2 integrons and their relationships to antibiotic resistance in clinical isolates of Shigella sonnei and Shigella flexneri. J Antimicrob Chemother. 2006;58:288-296.

95. Park YJ, Kim SY, Yu JK, Kim SI, Uh Y, Hong SG, Jongwook L, Kwak HS. Spread of Serratia marcescens coharboring aac(6')-Ib-cr, bla $a_{\mathrm{CTX- \textrm {M }}}$, armA, and $b l a_{\text {OXA-1 }}$ carried by conjugative IncL/M type plasmid in Korean hospitals. Microb Drug Resist. 2009;15(2):97-102.

96. Partridge SR, Hall RM. Complex Multiple Antibiotic and Mercury Resistance Region Derived from the r-det of NRI (R100). Antimicrob Agents Chemother. 2004;48:4250-4255.

97. Partridge SR, Hall RM. Evolution of transposons containing bla $\mathrm{TEM}_{\mathrm{TEM}}$ genes. Antimicrob Agents Chemother. 2005;49(3):1267-1268.

98. Partridge SR, Tsafnat G, Coiera E, Iredell R. Gene cassettes and cassette arrays in mobile resistance integrons. FEMS Microb Rev. 2009;33:757-784.

99. Paterson DL, Bonomo RA. Extended-spectrum beta-lactamases: a clinical update. Clin Microbiol Rev. 2005;18:657-686. 
100. Paterson DL, Hujer KM, Hujer AM, Yeiser B, Bonomo MD, Rice LB, Bonomo RA et al. Extended-spectrum $\beta$-lactamases in Klebsiella pneumoniae bloodstream isolates from seven countries: Dominance and widespread prevalence of SHV- and CTX-M-type $\beta$-lactamases. Antimicrob Agents Chemother. 2003;47:3554-3560.

101. Peirano G, Seki LM, Val Passos VL, Pinto MC, Guerra LR, Asensi MD. Carbapenem-hydrolysing beta-lactamase KPC-2 in Klebsiella pneumoniae isolated in Rio de Janeiro, Brazil. J Antimicrob Chemother. 2009;63(2):265-268.

102. Peirano G, Asensi MD, Pitondo-Silva A, Pitout JD. Molecular characteristics of extended-spectrum $\beta$-lactamase-producing Escherichia coli from Rio de Janeiro, Brazil. Clin Microbiol Infect. 2011 Jul;17(7):1039-1043.

103. Perilli M, Segatore B, Mugnaioli C, Celenza G, Rossolini GM, Stefani S, Luzzaro F, Pini B, Amicosante G. Persistence of TEM-52/TEM-92 and SHV-12 extended-spectrum $\beta$-lactamases in clinical isolates of Enterobacteriaceae in Italy. Microb Drug Resist. 2011;17(4):521-524.

104. Picão RC, Poirel L, Gales AC, Nordmann P. Diversity of beta-lactamases produced by ceftazidime-resistant Pseudomonas aeruginosa isolates causing bloodstream infections in Brazil. Antimicrob Agents Chemother. 2009;53(9):3908-3913.

105. Poirel L, Naas T, Nordmann P. Genetic support of extended-spectrum $\beta$ lactamases. Clin Microbiol Infect. 2008;14(s1):75-81.

106. Power P, Galleni M, Di Conza J, Ayala JA, Gutkind G. Description of In116, the

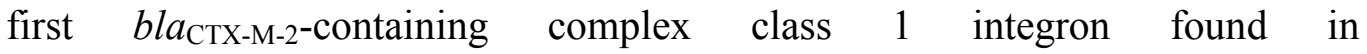
Morganella morganii isolates from Buenos Aires, Argentina. J Antimicrob Chemother. 2005;55(4):461-465.

107. Prado T, Pereira WC, Silva DM, Seki LM, Carvalho APDA, Asensi MD. Detection of extended-spectrum $\beta$-lactamase-producing Klebsiella pneumoniae in effluents and sludge of a hospital sewage treatment plant. Lett Appl Microbiol. 2008;46:136-141.

108. Queiroz ML, Antunes P, Mourão J, Merquior VL, Machado E, Peixe LV. Characterization of extended-spectrum beta-lactamases, antimicrobial resistance genes, and plasmid content in Escherichia coli isolates from different sources in Rio de Janeiro, Brazil. Diagn Microbiol Infect Dis. 2012;74(1):91-94.

109. Quiroga MP, Andres P, Petroni A, Soler Bistué AJ, Guerriero L, Vargas LJ, Zorreguieta A, Tokumoto M, Quiroga C, Tolmasky ME, Galas M, Centrón D. Complex class 1 integrons with diverse variable regions, including aac $\left(6^{\prime}\right)$ $I b-c r$, and a novel allele, qnrB10, associated with ISCRI in clinical enterobacterial isolates from Argentina. Antimicrob Agents Chemother. 2007 Dec;51(12):4466-4470. 
110. Radice M, Power P, Di Conza J, Gutkind G. Early dissemination of CTX-Mderived enzymes in South America. Antimicrob Agents Chemother. 2002;46:602-604.

111. Reinthaler FF, Feierl G, Galler $\quad$ H, Haas $\quad$ D, Leitner $\quad$ E, Mascher F, Melkes A, Posch J, Winter I, Zarfel G, Marth E. ESBL-producing E. coli in Austrian sewage sludge. Water Res. 2010;44(6):1981-1985.

112. Rodríguez-Baño J, Navarro MD. Extended-spectrum $\beta$-lactamases in ambulatory care: a clinical perspective. Clin Microbiol Infect. 2008;14(s1):104-110.

113. Rossolini GM, D'Andrea MM, Mugnaioli C. The spread of CTX-M-type extended-spectrum $\beta$-lactamases. Clin Microbiol Infect. 2008;14 (S1): 33-41.

114. Schlüter A, Szczepanowski R, Pühler A, Top EM. Genomics of IncP-1 antibiotic resistance plasmids isolated from wastewater treatment plants provides evidence for a widely accessible drug resistance gene pool. FEMS Microbiol Rev. 2007;31:449-477.

115. Segatore B, Setacci D, Perilli M, Franchino L, Franceschini N, Agnifili A, Rossolini GM, Amicosante G. Antimicrobial susceptibility of clinical isolates of Enterobacteriaceae producing complex beta-lactamase patterns including extended-spectrum enzymes. Int J Antimicrob Agents. 2004;23(5):480-486.

116. Sennati S, Santella G, Di Conza J, Pallecchi L, Pino M, Ghiglione B, Rossolini GM, Radice M, Gutkind G. Changing Epidemiology of Extended-Spectrum $\beta$ Lactamases in Argentina: Emergence of CTX-M-15. Antimicrob Agents Chemother. 2012;56(11):6003-6005.

117. Shahid M, Sobia F, Singh A, Khan HM. Concurrent occurrence of bla $a_{\mathrm{ampC}}$

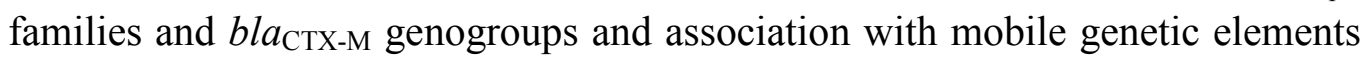
ISEcp 1, IS26, ISCR1, and sull-type class 1 integrons in Escherichia coli and Klebsiella pneumoniae isolates originating from India. $\mathrm{J}$ Clin Microbiol. 2012;50(5):1779-1782.

118. Shannon K, Stapleton P, Xiang X, Johnson A, Beattie H, El Bakri F, Cookson B, French G. Extended-spectrum beta-lactamase-producing Klebsiella pneumoniae strains causing nosocomial outbreaks of infection in the United Kingdom. J Clin Microbiol. 1998;36(10):3105-3110.

119. Snyder L, Champness W. Molecular Genetics of Bacteria. $2^{\text {nd }}$ ed. ASM Press; 1997. Genes and Genetic Elements; p.73-213.

120. Stalder T, Barraud O, Casellas M, Dagot C, Ploy MC. Integron involvement in environmental spread of antibiotic resistance. Front Microbiol. 2012;3:119.

121. Stoebel DM, Dorman CJ. The effect of mobile element IS10 on experimental regulatory evolution in Escherichia coli. Mol Biol Evol. 2010;27(9):2105-2112. 
122. Timmery S, Modrie P, Minet O, Mahillon J. Plasmid capture by the Bacillus thuringiensis conjugative plasmid pXO16. J Bacteriol. 2009;191(7):2197-2205.

123. Toleman MA, Bennett PM, Walsh TR. ISCR Elements: Novel Gene-Capturing Systems of the 21st Century? Microbiol Mol Biol Rev. 2006;70(2):296-316.

124. Toleman MA, Walsh TR. Combinatorial events of insertion sequences and ICE in Gram-negative bacteria. FEMS Microbiol Rev. 2011;35:912-935.

125. Tollentino FM, Polotto M, Nogueira ML, Lincopan N, Neves P, Mamizuka EM, Remeli GA, De Almeida MT, Rúbio FG, Nogueira MC. High prevalence of bla(CTX-M) extended spectrum beta-lactamase genes in Klebsiella pneumoniae isolates from a tertiary care hospital: first report of $b l a_{\mathrm{SHV}-12}, b l a_{\mathrm{SHV}-31}, b l a_{\mathrm{SHV}-38}$, and $b l a_{\mathrm{CTX}-\mathrm{M}-15}$ in Brazil. Microb Drug Resist. 2011;17(1):7-16.

126. Tristram SG, Pitout MJ, Forward K, Campbell S, Nichols S, Davidson RJ. Characterization of extended-spectrum beta-lactamase-producing isolates of Haemophilus parainfluenzae. J Antimicrob Chemother. 2008;61(3):509-514.

127. Turner MS, Andersson P, Bell JM, Turnidge JD, Harris T, Giffard PM. Plasmid-

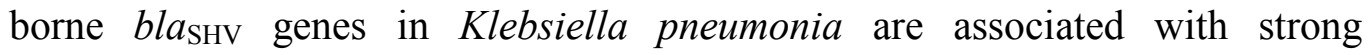
promoters. J Antimicrob Chemother. 2009;64:960-964.

128. Veras DL, Alves LC, Brayner FA, Guedes DR, Maciel MA, Rocha CR, de Souza Lopes AC. Prevalence of the bla $a_{\mathrm{SHV}}$ gene in Klebsiella pneumoniae isolates obtained from hospital and community infections and from the microbiota of healthy individuals in Recife, Brazil. Curr Microbiol. 2011;62(5):1610-1616.

129. Vignoli R, Varela G, Mota MI, Cordeiro M, Power P, Ingold E, Gadea P, Sirok A, Schelotto F, Ayala JA, Gutkind G. Enteropathogenic Escherichia coli strains carrying genes encoding the PER-2 and TEM-116 extended-spectrum $\beta$ lactamases isolated from children with diarrhea in Uruguay. J Clin Microbiol. 2005;43:2940-2943.

130. Vignoli R, Cordeiro N, Seija V, Schelotto F, Radice M, Ayala J, Power P, Gutkind G. Genetic environment of CTX-M-2 in Klebsiella pneumoniae isolates from hospitalized patients in Uruguay. Rev Argent Microbiol. 2006;38(2):84-88.

131. Villegas MV, Kattan JN, Quinteros MG, Casellas JM. Prevalence of extendedspectrum $\beta$-lactamases in South America. Clin Microbiol Infect. 2008;14:154158.

132. Vinué L, Sáenz Y, Martínez S, Somalo S, Moreno MA, Torres C, Zarazaga M. Prevalence and diversity of extended-spectrum beta-lactamases in faecal Escherichia coli isolates from healthy humans in Spain. Clin Microbiol Infect. 2009;15(10):954-957. 
133. Warren RE, Ensor VM, O’Neill P, Butler V, Taylor J, Nye K, Harvey M, Livermore DM, Woodford N, Hawkey PM. Imported chicken meat as a potencial source of quinolone-resistant Escherichia coli producing extendedspectrum $\beta$-lactamases in the UK. J Antimicrob Chemother. 2008;61:504-508.

134. Xu H, Su Z, Wang S, Dai X, Chen J, Kong F, Li Y, Peng S, Shao Q, Lu L, Ezaki T. Four novel resistance integron gene-cassette occurrences in bacterial isolates from Zhenjiang, China. Curr Microbiol. 2009;59(2):113-117.

135. Yokoe DS, Classen D. Improving patient safety through infection control: a new healthcare imperative. Infect Control Hosp Epidemiol. 2008;29(s1):s3-s11.

136. Zahrl D, Wagner A, Tscherner M, Koraimann G. GroEL plays a central role in stress-induced negative regulation of bacterial conjugation by promoting proteolytic degradation of the activator protein TraJ. J Bacteriol. 2007;189(16):5885-5894.

137. Zarnayová M, Siebor E, Péchinot A, Duez JM, Bujdáková H, Labia R, Neuwirth C. Survey of Enterobacteriaceae producing extended-spectrum beta-lactamases in a Slovak hospital: dominance of SHV-2a and characterization of TEM-132. Antimicrob Agents Chemother. 2005;49(7):3066-3069.

138. Zavascki AP, Carvalhaes CG, da Silva GL, Tavares Soares SP, de Alcântara LR, Elias LS, Sandri AM, Gales AC. Outbreak of carbapenem-resistant Providencia stuartii in an intensive care unit. Infect Control Hosp Epidemiol. 2012;33(6):627-630.

139. Zou LK, Wang HN, Zeng B, Zhang AY, Li JN, Li XT, Tian GB, Wei K, Zhou YS, Xu CW, Yang ZR. Phenotypic and genotypic characterization of $\beta$-lactam resistance in Klebsiella pneumoniae isolated from swine. Vet Microbiol. 2011;149(1-2):139-46 


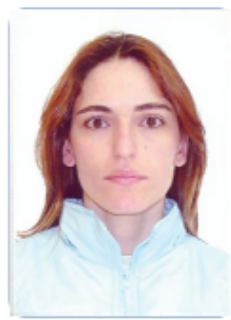

\section{Milena Dropa}

Endereço para acessar este CV: http://lattes.cnpq.br/8217707344487224

Última atualização do currículo em 26/01/2013

Possui graduação em Farmacia e Bioquimica pela Universidade Estadual de Ponta Grossa (2000) e Mestrado Em Saúde Pública pela Faculdade de Saude Publica (2006). Atualmente é Técnica de Nível Superior Nível III e aluna de Doutorado da Universidade de São Paulo. Tem experiência nas áreas de Análises Clínicas e Pesquisa, com ênfase em Microbiologia e Biologia Molecular, atuando principalmente nos seguintes temas: saúde pública, microbiologia, vigilância sanitária, infecção hospitalar e resistência bacteriana. (Texto informado pelo autor)

\section{Identificação}

\begin{tabular}{ll}
\hline Nome & Milena Dropa \\
Nome em citações bibliográficas & DROPA, M.;Dropa, M.;Dropa, Milena \\
Sexo & Feminino
\end{tabular}

\section{Endereço}

Endereço Profissional

Universidade de São Paulo, Faculdade de Saúde Pública.

Avenida Dr. Arnaldo, 715 Laboratorio de Pratica de Saude Publica

Cerqueira Cesar

01246-904 - Sao Paulo, SP - Brasil

Telefone: (11) 30617753

Ramal: 7753

Fax: (11) 30833501

URL da Homepage: http://www.fsp.usp.br

\section{Formação acadêmica/titulação}

2009

Doutorado em andamento em Doutorado em Saúde Pública.

Faculdade de Saúde Pública.

Tîtulo: Identificação e localização de genes de resistência a beta-lactâmicos,

detectados em cepas clínicas e ambientais de Enterobacteriaceae.,

Orientador: (9) Maria Helena Matté.

Palavras-chave: saúde pública; Resistência bacteriana; beta-lactamases de espectro estendido.

Grande área: Ciências da Saúde / Área: Saúde Coletiva / Subárea: Saúde Pública. Grande Área: Ciências da Saúde / Área: Saúde Coletiva / Subárea: Saúde Pública

/ Especialidade: Biologia Molecular.

Grande Área: Ciências da Saúde / Área: Saúde Coletiva / Subárea: Resistência Bacteriana.

$2004-2006$

Mestrado em Mestrado Em Saúde Pública.

Faculdade de Saude Publica.

Título: Caracterização genotípica de cepas da familia Enterobacteriaceae

produtoras de $\beta$-lactamases de espectro estendido, isoladas de pacientes de um 


\section{Maria Helena Matte}

Endereço para acessar este CV: http://lattes.cnpq.br/9695724992553294

última atualização do currículo em 10/01/2013

Maria Helena Matte (Texto informado pelo autor)

\section{Identificação}

\section{Nome}

Nome em citações bibliográficas

Sexo
Maria Helena Matte

MATIE, M. H.;Matte, M. H.;Matté, M.H.;Matté, M. H.

Feminino

\section{Endereço}

Endereço Profissional

Universidade de São Paulo, Faculdade de Saúde Pública, Departamento de Prática de Saúde Pública.

Avenida Doutor Arnaldo, 715

Cerqueira Cesar

01246904 - Sao Paulo, SP - Brasil

Telefone: (11) 30667769

Fax: (11) 8833501

URL da Homepage: http://

\section{Formação acadêmica/titulação}

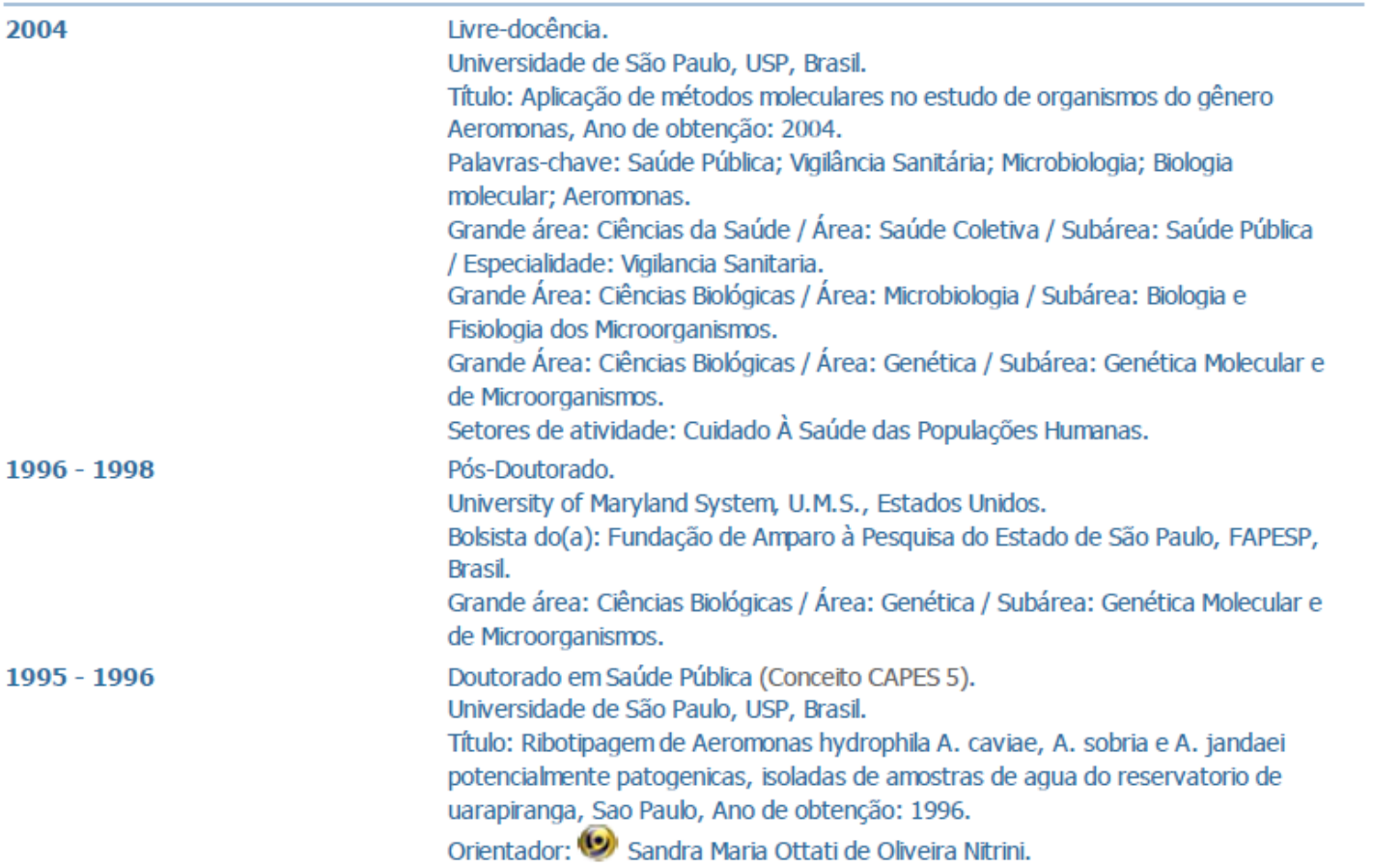

